OPEN ACCESS

Edited by:

Chrysi S. Laspidou,

University of Thessaly, Greece

Reviewed by:

Ljubica Tasic,

State University of Campinas, Brazi

Xiaohui Liu,

Chinese Research Academy of

Environmental Sciences, China

*Correspondence:

Cassia Boyadjian

cb30@aub.edu.lb

Specialty section:

This article was submitted to

Toxicology, Pollution and the

Environment,

a section of the journal

Frontiers in Environmental Science

Received: 01 September 2021

Accepted: 29 November 2021

Published: 22 December 2021

Citation:

Jalloul G, Keniar I, Tehrani A and

Boyadjian C (2021) Antibiotics Contaminated Irrigation Water: An

Overview on Its Impact on Edible Crops and Visible Light Active Titania

as Potential Photocatalysts for

Irrigation Water Treatment.

Front. Environ. Sci. 9:767963.

doi: 10.3389/fenvs.2021.767963

\section{Antibiotics Contaminated Irrigation Water: An Overview on Its Impact on Edible Crops and Visible Light Active Titania as Potential Photocatalysts for Irrigation Water Treatment}

\author{
Ghadeer Jalloul ${ }^{1}$, Imad Keniar ${ }^{2}$, Ali Tehrani ${ }^{3}$ and Cassia Boyadjian ${ }^{1 *}$ \\ ${ }^{1}$ Baha and Walid Bassatne Department of Chemical Engineering and Advanced Energy, Maroun Semaan Faculty of Engineering \\ and Architecture, American University of Beirut, Beirut, Lebanon, ${ }^{2}$ Department of Agriculture, Faculty of Agricultural and Food \\ Sciences, American University of Beirut, Beirut, Lebanon, ${ }^{3}$ Department of Bioproducts and Biosystems, Aalto University, Espoo, \\ Finland
}

Sub-therapeutic levels of antibiotics (ABs) are given to animals and poultry to promote growth and reduce disease. In agricultural environments, ABs reach croplands via animal manure used as fertilizer and/or ABs-contaminated water used for irrigation. The continuous discharge of $\mathrm{ABs}$ into the ecosystem raises growing concerns on the $\mathrm{ABs}$ contamination of edible crops. Tetracyclines (TCs) are among the most widely used ABs around the world. In this review, we discuss the contamination of irrigation water with TCs, its impact on edible crops, and the potential risks of crop contamination with TCs on human health. We propose solar-mediated photocatalytic degradation using Titania $\left(\mathrm{TiO}_{2}\right)$ photocatalyst as a promising method to remove TCs from irrigation water. The photocatalytic activity of $\mathrm{TiO}_{2}$ can be enhanced by chemical modification to expand its activity under visible light irradiation. Herein, we aim for providing literature-based guidance on developing a visible light-active $\mathrm{TiO}_{2}$-based system to degrade TCs and other ABs in water streams. We include a summary of recent advances on this topic based on three main modification methods of Titania: metal/non-metal/mixed doping, composite formation, and heterojunction construction. Among the investigated photocatalysts, $\mathrm{Fe}_{2} \mathrm{O}_{3}-\mathrm{TiO}_{2} / \mathrm{Fe}$-zeolite and the $\mathrm{N}$-doped $\mathrm{TiO}_{2} / \mathrm{rGO}$ immobilized composite catalysts were found to be very efficient in the degradation of TCs under visible light irradiation (i.e., 98\% degradation within $60 \mathrm{~min}$ ). Most immobilized $\mathrm{TiO}_{2}$ based composite systems exhibited improved performances and hence we highlight these as efficient, cost effective and ecofriendly photocatalysts for the degradation of TCs in irrigation water.

Keywords: antibiotics, crops, photocatalysis, $\mathrm{TiO}_{2}$, irrigation water

\section{INTRODUCTION}

Fresh water scarcity is an urgent global issue. Only (4\%) of water on earth is fresh, and increasing global population, climate change, urbanization, and over exploitation continue to contaminate this scarce resource (Gothwal and Shashidhar, 2015). Pharmaceutical and organic chemical contamination of water is a critical threat to the natural ecosystem and public health (Zeghioud 
et al., 2016). Amongst these pharmaceuticals, antibiotics (ABs) are a major concern (Anjali and Shanthakumar, 2019). ABs are natural or synthetic antimicrobial compounds used to treat bacterial infections in humans, animals, and plants by inhibiting or killing bacterial growth (Daghrir and Drogui, 2013; Anjali and Shanthakumar, 2019; Danner et al., 2019). $A B s$ have efficacious applications in human and veterinary medicine; however, sub-therapeutic $\mathrm{AB}$ levels are routinely given to animals and poultry to promote growth (Gothwal and Shashidhar, 2015). In agricultural environments, these ABs reach croplands via animal manure used as fertilizer and/or the use of AB-contaminated irrigation water (Anjali and Shanthakumar, 2019; You et al., 2019).

The escalating use of $\mathrm{ABs}$ and their continuous discharge into the environment results in frequent detection of $\mathrm{ABs}$ in different environments, with concentrations of $\mathrm{ng} / \mathrm{L}-\mathrm{mg} / \mathrm{L}$ in wastewater (Pan and Chu, 2017). Wastewater is commonly used for irrigating agricultural lands due to the scarcity of fresh water. There is evidence from greenhouse and field experiments that irrigating crops with ABs-contaminated water leads to crop contamination; studies performed on different edible crops (lettuce, cucumber, spinach, and pepper) using different groups of $\mathrm{ABs}$ detected these ABs in plant leaves and roots (Pan and Chu, 2017).

Bioaccumulation of $\mathrm{ABs}$ in edible crops and in water environments lead to potential risks to human health. The proliferation of $\mathrm{ABs}$ in the environment led to the emergence of antibiotic resistant bacteria and antibiotic resistance genes (Singh et al., 2019). Antibiotic resistance is defined as the ability of the target microbe to resist the action of the antibiotic drug that previously caused cell death. In human health, antibiotic resistant bacteria cause untreatable infections and increased mortality (Chen M. et al., 2019; Singh et al., 2019). Human consumption of ABs-contaminated edible crops and drinking water poses major health risks due to the potential antibiotic resistance transfer to human pathogens (Sponza and Koyuncuoglu, 2019). Current reports indicate that antibiotic resistance is an urgent health-threatening issue, causing 0.7 million deaths/year and estimated to grow to 10 million deaths by 2050 (Singh et al., 2019).

There are currently 250 different antibiotics classified in seven groups (Anjali and Shanthakumar, 2019). Tetracyclines are reported as the second most widely used $\mathrm{AB}$ group worldwide (Xu L. et al., 2021). Tetracyclines are a group of ABs that include chlortetracycline, oxytetracycline, tetracycline hydrochloride, and tetracycline (Daghrir and Drogui, 2013). Tetracyclines have gained specific attention due to their wide use in medical, agricultural, and poultry sectors, and due to their poor adsorption in humans and animals and high stability in soil and wastewater (Saadati et al., 2016a). For example (50-80\%), of the tetracycline consumed by humans/animals is excreted through urine and feces, and they are stable in wastewater for 34-329 h due to their low volatility and high hydrophobicity (Daghrir and Drogui, 2013; Xu L. et al., 2021). Sources for tetracyclines discharge include pharmaceutical industries, farms, homes, and hospitals. Hence, the occurrence of these $\mathrm{ABs}$ in the environment is proportional to the economic status of the country and the size of the livestock and the pharmaceutical industries. On the other hand, TCs discharge into the environment is also a consequence of the inefficiency of the current water treatment technologies used in removing these $\mathrm{ABs}$ (Christou et al., 2017; Pan and Chu, 2017). Particularly, tetracyclines are detected in the low $(\mu \mathrm{g} / \mathrm{L})$ level in municipal wastewater, in the high $(\mu \mathrm{g} / \mathrm{L})$ level in hospital wastewater, and in the $(\mathrm{ng} / \mathrm{L})$ level in underground, surface, and sea water (Homem and Santos, 2011). Although these concentrations appear low, they still impose risks to human health and the ecosystem via the potential development of antibacterial resistance (Danner et al., 2019).

Numerous studies have worked to develop efficient methods for removing $\mathrm{ABs}$ and specifically tetracyclines from water streams to eliminate potential threats to the ecosystem and humans (Saadati et al., 2016a; Minale et al., 2020). Removal technologies include adsorption, conventional technologies (biological processes, coagulation, flocculation, sedimentation, and filtration), membrane processes, chlorination, and advanced oxidation methods such as photolysis, electrochemistry, and photocatalysis (Homem and Santos, 2011; Wei et al., 2020). However, most of the conventional technologies such as the biological methods, filtration, coagulation/flocculation/sedimentation, and membrane processes suffer from the drawbacks of low efficiency, low degradation rate, incomplete mineralization, and high toxicity (Homem and Santos, 2011; Anjali and Shanthakumar, 2019). Solar light-activated photocatalytic degradation of $\mathrm{ABs}$ is an efficient, safe, residue-free, economical, and ecofriendly method to remove tetracyclines from wastewater, especially under visible light and ambient conditions (Homem and Santos, 2011; Wei et al., 2020). Various semiconductors and photocatalysts have been investigated for the photocatalytic degradation of tetracyclines including $\mathrm{ZnO}, \mathrm{TiO}_{2}, \mathrm{WO}_{3}, \mathrm{CdS}$, $\mathrm{Fe}_{3} \mathrm{O}_{4}$, g- $\mathrm{C}_{3} \mathrm{~N}_{4}, \mathrm{ZnS}$, and $\mathrm{Bi}_{2} \mathrm{O}_{3}$ (Niu et al., 2013; Zhu et al., 2013; Zhang et al., 2014; Li et al., 2015; Vázquez et al., 2016; Wang T. et al., 2017; Yan et al., 2020). Semiconductors based on Titania $\left(\mathrm{TiO}_{2}\right)$ are the most widely studied catalysts due to their low cost, high stability, low toxicity, good activity, and ease of modification (Teoh et al., 2012; Ibhadon and Fitzpatrick, 2013; Koe et al., 2019; You et al., 2019; Zhang et al., 2019). However, the photocatalytic activity and application of $\mathrm{TiO}_{2}$ is limited to the UV region of the light spectrum (200-400 nm), and further modifications are needed to expand its activity into the visible light region (400-700 nm). Recently, immense efforts have been dedicated for $\mathrm{TiO}_{2}$ modification to expand its activity to the visible light region, and several modification methods and approaches have been reported (Basavarajappa et al., 2020).

This review discusses the escalating use of ABs; their continuous discharge into the agroecosystems contaminating both the soil and water; and the risks associated with using wastewater for crop irrigation. We present a summary of the latest literature studying the impact of ABs-contaminated irrigation water on the quality of edible crops and potential consequences for human health. Current research indicates that the use of ABs-contaminated irrigation water has potential risks to humans and ecosystems, and highlights an urgent need to develop efficient irrigation water treatment 
technologies. Here, we focus on tetracyclines degradation under visible light using $\mathrm{TiO}_{2}$-based photocatalysts, and present a detailed summary of the latest advances in Titania modification to enhance its visible light activity for the photocatalytic degradation of tetracyclines in water. $\mathrm{We}$ identify the most efficient catalysts and discuss their advantages and disadvantages. For literature collection, we focused on studies investigating modified Titania-based catalysts for the photocatalytic degradation of tetracyclines under visible light irradiation between 2011 and 2021. We chose to discuss the three most reported modification methods; metal-nonmetal, mixed metal-nonmetal doping, $\mathrm{TiO}_{2}$-based composite formation, and $\mathrm{TiO}_{2}$-based heterojunction construction. For TCs presence in the environment, we adopted numerical data from recent studies which assessed the occurrence of TCs in various water media and their bioaccumulation in edible crops.

\section{IMPACT OF ABs-CONTAMINATED IRRIGATION WATER ON EDIBLE CROPS AND POTENTIAL RISKS FOR HUMAN HEALTH}

Fresh water scarcity has led to the reuse of wastewater for crop irrigation. Approximately $20 \times 10^{10} \mathrm{~m}^{2}$ of global agricultural land is irrigated with treated wastewater (Raschid-Sally and Jayakody, 2008). Countries that extensively use reclaimed water for irrigation include Australia, Columbia, United States, and China (Gudda et al., 2020). Conventional water treatment methods (coagulation, flocculation, sedimentation, and filtration) and biological treatment methods are only moderately effective in removing low concentrations of persistent organic contaminants such as antibiotics. Generally, these methods have very low efficiency in removing ABs from wastewater, and the efficiency depends on the physiochemical properties of the $\mathrm{AB}$ to be removed and the operating conditions of the treatment system (Pan et al., 2014; Christou et al., 2017). The use of reclaimed wastewater for crop irrigation introduces these organic contaminants into the soil and ultimately to crops.

Antibiotics have been detected in diverse edible crops. For example, in Minnesota, United States, sulfamethoxazole was detected in Lactuca sativa (lettuce) at concentrations of $100-1,200 \mu \mathrm{g} / \mathrm{kg}$ tissue (Christou et al., 2017). In Tianjin, China, tetracycline and sulfamethoxazole were detected in spinach and radish at concentrations of $6.3-330 \mu \mathrm{g} / \mathrm{kg}$ tissue (Hu et al., 2010). In the Pearl River delta, China, tetracyclines were detected in cabbage and Ipomoea aquatica (water spinach) at concentrations of 6.6 and $7.4 \mu \mathrm{g} / \mathrm{kg}$ tissue, respectively (Pan et al., 2014).

Several studies investigated the impact of ABs-contaminated irrigation water on the uptake of the crops of these contaminants. Both greenhouse (pot) and field experiments were reported. Herein, we present results of some of these experiments. In the summer of 2020, we conducted pot experiments to evaluate the accumulation of gentamicin and oxytetracycline in three crops that are consumed fresh, including radish, lettuce, and cucumber (Imad Keniar et al., 2021). The crops were irrigated with $20 \mathrm{mg} / \mathrm{L}$ of each of the studied ABs. After harvesting, these ABs were detected in crop extracts using ELISA. The results detected gentamicin accumulation up to 13,16 , and $18 \mathrm{ng} / \mathrm{g}$ in cucumber, lettuce, and radish, respectively, whereas oxytetracycline accumulation was less than $3.0 \mathrm{ng} / \mathrm{g}$ in all three crops. Azanu et al. (Azanu et al., 2016) evaluated the accumulation of tetracycline and amoxicillin in potted lettuce and carrot irrigated with water containing known concentrations of $0.1-15 \mathrm{mg} / \mathrm{L}$ of tetracycline and amoxicillin. ABs were extracted from lettuce leaves and carrot tubers using accelerated solvent extraction, and then analyzed using liquid chromatography-tandem mass spectrometry. Tetracycline was detected in concentrations ranging between 4.4 and $28.3 \mathrm{ng} / \mathrm{g}$ in lettuce, and $12-36.8 \mathrm{ng} / \mathrm{g}$ in carrots. Whereas, amoxicillin was detected in concentrations ranging between 13.7 and $45.2 \mathrm{ng} / \mathrm{g}$ in both crops, which indicated that the amoxicillin uptake by lettuce and carrot was significantly higher than that of tetracycline. Hussein et al. (Hussain et al., 2016) conducted a field study in Lahore, Pakistan, which irrigated wheat, spinach, and carrot using pharmaceutical wastewater. The results showed that each of these crops accumulated $0-1 \mathrm{ng} / \mathrm{g}$ tissue of ciprofloxacin, ofloxacin, levofloxacin, oxytetracycline, and doxycycline.

Current data provide clear evidence that the use of ABscontaminated irrigation wastewater can contaminate the soil and ultimately lead to ABs accumulation in edible crops. The extent of plant uptake of $\mathrm{ABs}$ from contaminated water depend on the type and concentration of the $A B$, its water solubility, sorption potential, and lipophilicity (Azanu et al., 2016). A clear understanding of $\mathrm{AB}$ bioaccumulation in crops and their ecotoxicological effects requires greater knowledge of the physiochemical properties of $\mathrm{ABs}$ in the soil and the mechanism of their translocation and bioaccumulation in plants (Pan and Chu, 2017). Field studies are necessary to accurately assess ABs uptake by various crops under different environmental conditions, and determine the impact of $\mathrm{ABs}$ accumulation in these crops (Pan and Chu, 2017).

Excessive use of treated wastewater in agriculture is increasing the risk of transmitting $\mathrm{AB}$ resistant pathogens/genes to the crops, which could potentially be transferred to the human microbiome through the food chain (Gudda et al., 2020). The level of this risk on human health will depend on the level of exposure to these contaminated crops through consumption. Pan et al. (Pan and Chu, 2017) proposed that human exposure to ABs through annual consumption of edible crops grown in manureamended or wastewater-irrigated soil is likely to be low. For example, assessments of annual human exposure to different ABs through consumption of various crops in China indicated that consumption of corn and rice led to the highest $\mathrm{AB}$ exposure. The daily human exposure to tetracyclines, quinolones, and chloramphenicol was assessed as (0.34-2.77 $\mu \mathrm{g})$ and $(11.0-21.8 \mu \mathrm{g})$ via consumption of corn and rice, respectively. These values remained lower than the recommended acceptable daily intake (20-200 mg/day) of these ABs. However, a comprehensive analysis of the impact of $\mathrm{AB}$-contaminated edible crops on human health is lacking. This would require 
TABLE 1 | Maximum detected tetracyclines concentrations in different environments and different countries (Pan and Chu, 2017).

\begin{tabular}{|c|c|c|c|c|c|}
\hline Antibiotic & Wastewater ( $\mu \mathrm{g} / \mathrm{L})$ & Soil $(\mu \mathrm{g} / \mathrm{g})$ & Manure $(\mu \mathrm{g} / \mathrm{g})$ & Biosolid $(\mu \mathrm{g} / \mathrm{g})$ & Plants $(\mu g / g)$ \\
\hline Tetracycline & 254.820 & 0.178 & 43.500 & 0.513 & 0.0101 \\
\hline Country & Korean & Korean & China & Canada & China \\
\hline Oxytetracycline & 1.236 & 2.683 & 183.500 & 0.7436 & 0.330 \\
\hline Country & South Korean & China & China & United States & China \\
\hline Chlortetracycline & 444.20 & 107.9 & 268.00 & 0.3466 & 0.532 \\
\hline Country & Korean & China & China & United States & China \\
\hline
\end{tabular}

well-defined dietary studies to develop human exposure models and further integrate those models with disease outbreak analysis and clinical data. This will help estimate the relationship between the ingestion of $\mathrm{AB}$ resistant pathogens and their impact on human defense mechanisms and health (Pan and Chu, 2017; Sanganyado and Gwenzi, 2019).

\section{TETRACYCLINES OCCURRENCE IN WATER ENVIRONMENTS}

This review focuses on the tetracyclines group as model ABs. Tetracyclines are one of the most prescribed ABs in human and animal infectious therapies due to their wide antimicrobial spectrum and low cost (Minale et al., 2020; Xu L. et al., 2021). Tetracyclines are extensively utilized as fertilizers and growth promoters in animal husbandry and agricultural industries (Daghrir and Drogui, 2013). Approximately (70\%) of locally produced antibiotics are used for non-medical applications in the United States, and 4,200 tons of tetracyclines are utilized only in the agricultural industry (Xu L. et al., 2021). Tetracyclines have poor adsorption in humans/animals and high stability in soil and wastewater (Saadati et al., 2016a). For example (50-80\%), of tetracyclines consumed by humans/animals are excreted through urine and feces, and after discharge into aquatic media, they are stable for $34-329 \mathrm{~h}$ due to their low volatility and high hydrophobicity (Daghrir and Drogui, 2013; Xu L. et al., 2021). $\mathrm{AB}$ contaminants are also persistent in soil and slowly degrade; for example, it took 90 days to degrade (44-75\%) of the initial tetracycline concentration in a sterilized soil (Pan and Chu, 2017). Tetracyclines are released into the environment through animal manure, biosolids, sewage discharge, pharmaceutical wastewater, and the use of $\mathrm{ABs}$-contaminated wastewater for irrigation (Pan and $\mathrm{Chu}, 2017)$. The $\mathrm{AB}$ concentration in each medium is directly related to the pollution source(s) and their distance from the medium. Tetracyclines are detected at low $\mu \mathrm{g} / \mathrm{L}$ concentrations in municipal wastewater, at high $\mu \mathrm{g} / \mathrm{L}$ concentrations in hospital wastewater, and at ng/L concentrations in underground, surface, and sea water (Homem and Santos, 2011). Although these concentrations seem rather low, they still carry risks for human health and the ecosystem through the development of antibiotic resistant bacteria and antibiotic resistance genes (Danner et al., 2019).

Table 1 presents the maximum detected concentration ranges of tetracycline, oxytetracycline, and chlortetracycline in wastewater, soil, manure, biosolids, and plants in different countries. The highest concentrations of tetracycline and chlortetracycline were detected in wastewater, whereas the highest concentration of oxytetracycline was in manure. The highest tetracycline concentrations detected in wastewater were tetracycline $254.820 \mu \mathrm{g} / \mathrm{L}$ in Korea, chlortetracycline $44.420 \mu \mathrm{g} / \mathrm{L}$ in Korea, and oxytetracycline $1.236 \mu \mathrm{g} / \mathrm{L}$ in South Korea. The highest tetracyclines concentrations detected in soil, manure, and biosolids were $2.683,183.500$, and $0.7436 \mu \mathrm{g} / \mathrm{g}$ of oxytetracycline, in China and United States. The highest tetracycline concentration detected in plant contamination was $0.532 \mu \mathrm{g} / \mathrm{g}$ of chlortetracycline in China.

Several studies have investigated ABs contamination of surface water. Table 2 presents the concentrations of tetracyclines in surface water streams in different countries. The predominant tetracycline detected in Ghana (Africa) was chlortetracycline, at concentrations of $0.044 \mu \mathrm{g} / \mathrm{L}$. In the Wangyang River in China, tetracycline was detected at $25.5 \mu \mathrm{g} / \mathrm{L}$. In Europe, the highest tetracycline concentration in surface water was detected in the United Kingdom, at a concentration of $1 \mu \mathrm{g} / \mathrm{L}$. In the United States, the highest concentration of tetracycline $102.7 \mu \mathrm{g} / \mathrm{L}$ was detected in the Poudre River, Colorado. In Australia, the tetracycline concentration in surface water was minimal $0.008 \mu \mathrm{g} / \mathrm{L}$.

The varying levels of tetracycline contaminants in different countries reflect the scale of production and usage of tetracyclines in each country. This in turn is directly correlated to the economic development and industrial scale of the country. The highest concentrations of tetracyclines were detected in China, which is the biggest producer and consumer of ABs in the world. In 2013, China produced (248,000 tons) of $\mathrm{ABs}$ and consumed approximately (162,000 tons) (Zhang et al., 2015). China was the highest consumer of veterinary ABs in the livestock industry, reaching approximately (15,000 tons) in 2010 (Robles Jimenez et al., 2019). China will double its $A B$ consumption in the livestock industry by 2030, when it will reach up to (35,000 tons) (Robles Jimenez et al., 2019). Tetracyclines were not detected in surface water in Lebanon (Mokh et al., 2017), likely due to the low scale of livestock activity. However, the latest Lebanese Ministry of Agriculture survey in 2009 reports rapid growth in livestock productivity (Mokh et al., 2020). Farmers use different groups of ABs to promote growth in cattle and poultry. Studies evaluating the presence of $\mathrm{AB}$ residues in cattle and poultry in different regions in Lebanon documented $A B$ bioaccumulation in these animals. For example, a 2008 survey investigated the most widely used ABs in dairy cows from 26 random farms (more than $50 \%$ of them were small-scale farms with less than 1,000 cattle), and found wide use of streptomycin, gentamicin, penicillin, kanamycin, and oxytetracycline (Abi 
TABLE 2 | Maximum tetracyclines concentrations in different surface water streams in different countries (Danner et al., 2019; Singh et al., 2019).

\begin{tabular}{|c|c|c|c|}
\hline Continent & Country & Antibiotic & Concentration $(\mu \mathrm{g} / \mathrm{L})$ \\
\hline \multirow[t]{3}{*}{ Africa } & Ghana (rivers) & Tetracycline & 0.03 \\
\hline & Ghana & Oxytetracycline & 0.026 \\
\hline & Ghana & Chlortetracycline & 0.044 \\
\hline \multirow[t]{4}{*}{ Asia } & Hong Kong & Tetracycline & 0.0315 \\
\hline & China (Wangyang River) & Tetracycline & 25.5 \\
\hline & China (Huangpu River) & Oxytetracycline & 0.0845 \\
\hline & China & Chlortetracycline & 0.017 \\
\hline \multirow[t]{9}{*}{ Europe } & Luxembourg (Alzette River) & Tetracycline & 0.008 \\
\hline & United Kingdom & Tetracycline & 1 \\
\hline & Spain & Tetracycline & 0.228 \\
\hline & France & Tetracycline & 0.007 \\
\hline & Poland (Drweca River) & Tetracycline & 0.034 \\
\hline & Croatia & Chlortetracycline & 0.43 \\
\hline & France & Chlortetracycline & 0.68 \\
\hline & Luxembourg & Chlortetracycline & 0.007 \\
\hline & Spain & Chlortetracycline & 0.059 \\
\hline \multirow[t]{5}{*}{ America } & Cuba & Tetracycline & 0.155 \\
\hline & United States (Poudre River) & Tetracycline & 102.7 \\
\hline & Canada & Tetracycline & 0.035 \\
\hline & Brazil & Tetracycline & 0.011 \\
\hline & United States & Oxytetracycline & 1.34 \\
\hline Australia & Australia (rivers) & Tetracycline & 0.08 \\
\hline
\end{tabular}

Khalil, 2008). Jammoul et al. (Jammoul and El Darra, 2019) evaluated $\mathrm{ABs}$ in 80 chicken muscle samples from different regions of Lebanon, and detected contaminating $\mathrm{AB}$ residues in (77.5\%) of these samples. Ciprofloxacin (quinolones) represented the highest occurrence percentage (32.5\%), followed by amoxicillin (lactams) (22.5\%) and then tetracyclines (17.5\%). The tetracyclines detected in these samples were below the maximum residue limit (MRL) values of $200 \mu \mathrm{g} / \mathrm{kg}$ set by the Food and Agriculture Organization (FAO, 2018). There are no recent studies on $A B$ bioaccumulation in edible crops and water environments in Lebanon.

\section{PHOTOCATALYTIC DEGRADATION AS A POTENTIAL TREATMENT FOR CONTAMINATED IRRIGATION WATER}

\subsection{Photocatalysis}

Antibiotics are stable in natural environments and persist in aquatic media because they are only partly biodegradable and are not completely removed by traditional wastewater treatment methods (only 24-36\% removal efficiency) (Zeghioud et al., 2016; Pan and Chu, 2017). Hence, there is an urgent need to develop new technologies to detoxify wastewater streams by degrading these pharmaceuticals (Zeghioud et al., 2016). There are two main technologies to remove $\mathrm{ABs}$ from the environment: destructive and non-destructive methods.

Non-destructive methods include adsorption, liquid extraction, and membrane separation. Adsorption relies on solid and liquid phases, and the ability of the pollutant to move from the liquid phase to attach onto the solid adsorbent (Anjali and Shanthakumar, 2019). The adsorption efficiency depends on the properties of the adsorbent, including its surface area, porosity, and pore diameter (Homem and Santos, 2011). Conventional treatments refer to methods that are utilized in water treatment plants, and include biological methods, filtration and coagulation/flocculation/sedimentation. In the biological systems, the organic compound degradation occurs in activated sludge tanks with the absence or presence of oxygen gas $\left(\mathrm{O}_{2}\right)$ by monitoring the temperature and chemical oxygen demand. Filtration is the elimination of suspended solids in the feed by passing it over a granular solid medium, like sand, activated carbon, or coal. Coagulation/flocculation/sedimentation use particular chemicals like iron salts, polymers, lime, and alum to facilitate pollutant precipitation, particle sedimentation, and colloid generation to further collect them. (Homem and Santos, 2011). Membrane separation methods include reverse osmosis, nanofiltration, ultrafiltration, and ion exchange. These techniques do not degrade or remove contaminants, but entrap organic pollutants on filters (membranes) that require regeneration or disposal. The organic compounds and salts in contaminated wastewater affect the system performance and cause fouling of the membrane, leading to flux deterioration (Homem and Santos, 2011; Anjali and Shanthakumar, 2019). Ion exchange is based on anion and cation exchange between liquid and solid phases (sorbent/ membrane), and is primarily used to improve water quality. It is rarely used to remove $\mathrm{ABs}$ from wastewater because this method requires $\mathrm{ABs}$ molecules to have ionizable groups (Homem and Santos, 2011).

Destructive methods include biodegradation and chemical oxidation processes (Calvete et al., 2019). Chemical oxidation processes include chlorination and advanced oxidation 
TABLE 3 | Summary of methods for antibiotics removal from wastewater (Homem and Santos, 2011; Anjali and Shanthakumar, 2019).

\begin{tabular}{|c|c|c|c|}
\hline Process & Advantages & Disadvantages & Examples of antibiotic \\
\hline Adsorption & $\begin{array}{l}\text { Can be applied to feeds with high } \\
\text { concentrations of organic compounds and } \\
\text { antibiotics }\end{array}$ & $\begin{array}{l}\text { It only concentrates pollutants in the } \\
\text { adsorbent medium that need to be treated } \\
\text { or disposed of later. It is not widely used to } \\
\text { remove tetracyclines from water }\end{array}$ & $\begin{array}{l}\text { Oxytetracycline and Tetracycline Choi et al. } \\
\text { (2008) Chlortetracycline Chen and Huang, } \\
\text { (2010) Sulfamerazine Koyuncu et al. (2008) }\end{array}$ \\
\hline Conventional & $\begin{array}{l}\text { It can be applied to effluents with high flow } \\
\text { rates }\end{array}$ & $\begin{array}{l}\text { It has low removal efficiency and complex } \\
\text { removal of coagulated pollutants. It is not } \\
\text { applied to fluid streams with high pollutant } \\
\text { concentrations due to its toxicity }\end{array}$ & $\begin{array}{l}\text { Trimethoprim Kim et al. (2010) } \\
\text { Sulfamethazine and Sulfadimethoxine Göbel } \\
\text { et al. (2007) }\end{array}$ \\
\hline $\begin{array}{l}\text { Membrane technology (reverse } \\
\text { osmosis, nano-filtration, and } \\
\text { ultrafiltration) }\end{array}$ & $\begin{array}{l}\text { Efficiently reduce high levels of dissolved } \\
\text { salts. They do not require thermal energy }\end{array}$ & $\begin{array}{l}\text { These methods are slow and inefficient when } \\
\text { treating organic compounds such as } \\
\text { pharmaceuticals. They are vulnerable to } \\
\text { membrane fouling that reduces the efficiency }\end{array}$ & $\begin{array}{l}\text { Sulfamethoxazole Radjenović et al. (2008) } \\
\text { Sulfamerazine Adams et al. (2002) } \\
\text { Oxytetracycline Kosutic et al. (2007) }\end{array}$ \\
\hline Ion exchange & $\begin{array}{l}\text { Reversible method that allows the resin or } \\
\text { membrane to be reused after regeneration }\end{array}$ & $\begin{array}{l}\text { Susceptible to fouling and requires } \\
\text { backwashing. Rarely used for antibiotic } \\
\text { removal }\end{array}$ & $\begin{array}{l}\text { Sulfamethoxazole Tetracyclines } \\
\text { Chlortetracycline Oxytetracycline Choi et al. } \\
\text { (2007) Trimethoprim Adams et al. (2002) }\end{array}$ \\
\hline Chlorination & $\begin{array}{l}\text { Efficiently removes antibiotics from water } \\
\text { containing low percentages of organic } \\
\text { compounds }\end{array}$ & $\begin{array}{l}\text { Its efficiency is function of the system } \mathrm{pH} \text {. It } \\
\text { can generate halogenated compounds, } \\
\text { which are potentially carcinogenic }\end{array}$ & $\begin{array}{l}\text { Amoxicillin and Erythromycin Navalon et al. } \\
\text { (2008) Sulfamethoxazole Stackelberg et al. } \\
\text { (2007) Sulfamerazine (Adams et al., 2002) }\end{array}$ \\
\hline Photocatalysis & $\begin{array}{l}\text { Can be applied under ambient conditions. } \\
\text { Can save energy by utilizing solar light }\end{array}$ & $\begin{array}{l}\text { Has not been industrialized due to the low } \\
\text { light penetration in large-scale applications in } \\
\text { slurry reactors. Difficult to remove and } \\
\text { regenerate the catalyst }\end{array}$ & $\begin{array}{l}\text { Amoxicillin Klauson et al. (2010) Lincomycin } \\
\text { (Addamo et al., 2005) Tetracycline Zhu et al. } \\
\text { (2013) }\end{array}$ \\
\hline Electrochemical oxidation & $\begin{array}{l}\text { Clean, easy, and effective method to } \\
\text { remove high concentrations of antibiotics } \\
\text { and toxic organic matter }\end{array}$ & $\begin{array}{l}\text { Limited to small flow rates. Has high capital } \\
\text { and operating costs }\end{array}$ & $\begin{array}{l}\text { Lincomycin Carlesi Jara et al. (2007) } \\
\text { Anthracyclines Hirose et al. (2005) } \\
\text { Enrofloxacin Guinea et al. (2009) }\end{array}$ \\
\hline Photolysis & $\begin{array}{l}\text { Can be applied to wastewater containing } \\
\text { photosensitive compounds and low } \\
\text { chemical oxygen demand (COD) } \\
\text { percentages }\end{array}$ & $\begin{array}{l}\text { It is less effective than other techniques that } \\
\text { use UV light along with catalysts or other } \\
\text { additives. It is ineffective in treating } \\
\text { wastewater contaminated with antibiotics }\end{array}$ & $\begin{array}{l}\text { Penicillin Arslan-Alaton and Dogruel, (2004) } \\
\text { Ciprofloxacin Vieno et al. (2007) } \\
\text { Oxytetracycline Jiao et al. (2008) }\end{array}$ \\
\hline Fenton and photofenton & $\begin{array}{l}\text { These methods have good degradation } \\
\text { percentages. They can be applied to } \\
\text { wastewater with low COD concentrations }\end{array}$ & $\begin{array}{l}\text { Photofenton cannot be applied to streams } \\
\text { with high organic (pharmaceutical) contents } \\
\text { due to water turbidity, which blocks light } \\
\text { irradiation needed for catalyst activation. } \\
\text { Sludge formation as function of the system } \\
\text { pH remains challenging in these systems }\end{array}$ & $\begin{array}{l}\text { Amoxicillin Zhang et al. (2006) Penicillin } \\
\text { Arslan-Alaton and Dogruel, (2004) } \\
\text { Lincomycin Bautitz and Nogueira, (2010) }\end{array}$ \\
\hline Ozonation & $\begin{array}{l}\text { It has acceptable pollutant degradation } \\
\text { efficiency. It is suitable for the treatment of } \\
\text { feeds with variable compositions }\end{array}$ & $\begin{array}{l}\text { Expensive. Low mineralization percentage. } \\
\text { High toxicity. High capital, operating, and } \\
\text { maintenance costs }\end{array}$ & $\begin{array}{l}\text { Amoxicillin Andreozzi et al. (2005) } \\
\text { Sulfamethoxazole (Huber et al., 2003) } \\
\text { Oxytetracycline Li et al. (2008) }\end{array}$ \\
\hline
\end{tabular}

processes. Chlorination oxidizes organic pollutants into less toxic and biodegradable compounds. This method uses low-cost gases such as chlorine and hypochlorite, and it is routinely used as a pretreatment for wastewater streams polluted with pharmaceutical contaminants that are to be treated in biological systems (Homem and Santos, 2011). Advanced oxidation processes oxidize organic pollutants using intermediate radicals such as hydroxyl radicals to transform them into less toxic and more biodegradable species. The intermediate radicals are very reactive, have lower selectivity than other oxidants, and are generated in the presence of ozone, hydrogen peroxide, ultraviolet radiation, or semiconductor photocatalyst (Homem and Santos, 2011). Examples of advanced oxidation processes include ozonation, fenton, and photofenton oxidation, photolysis, electrochemical technologies, and photocatalysis.

The most studied AB removal technologies include ozonation, fenton/photofenton oxidation, photolysis, photocatalysis, electrochemical oxidation, chlorination, ion exchange, membrane technologies, and adsorption (Anjali and Shanthakumar, 2019; Homem and Santos, 2011). Table 3 presents the advantages and disadvantages of each method. Photocatalysis is considered an environmentally friendly and low cost detoxification technique due to its utilization of solar light and complete mineralization of organic pollutants without generating residual waste or sludge (Sundar and Kanmani, 2020). Complete mineralization of the pollutant converts it into harmless species such as water, carbon dioxide, nitrogen, and other by-products, which in most cases are nontoxic (Zeghioud et al., 2016). The potential toxicity of products generated by photocatalytic degradation can be minimized by achieving high photocatalytic-induced mineralization (>99\%) (Libralato et al., 2020). BouafiaChergui et al. (Bouafia-Chergui et al., 2016) studied the toxicity of products generated by photocatalytic degradation 
1. Transportation of pollutant

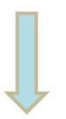

2. Adsorption of pollutant

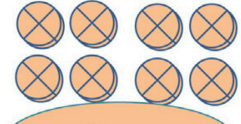

Pollutant

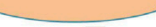

3. Degradation Reaction

$\mathrm{CO}_{2}$ and $\mathrm{H}_{2} \mathrm{O}$
4. Desorption of products

5. Transportation of products

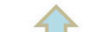

(1)

\section{$=$}

\section{$h^{+} \quad \mathrm{H}_{2} \mathrm{O}$ Catalyst $\boldsymbol{e}^{-} \quad \mathrm{O}_{2}$}

FIGURE 1 | A schematic of photocatalytic reaction steps.

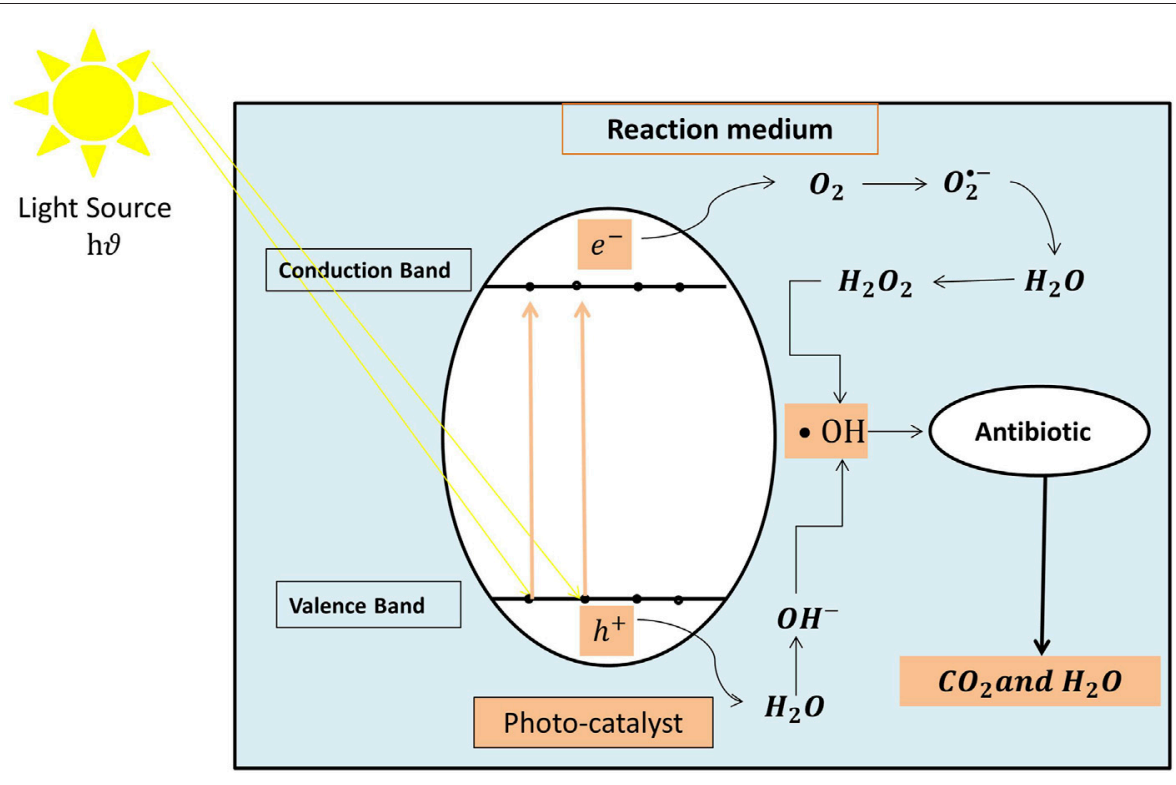

FIGURE 2 | Illustration of photocatalytic degradation mechanism.

of tetracycline by $\mathrm{TiO}_{2}$ under UV light. The toxicity was evaluated by observing variations in the natural luminescent emissions of Vibrio fischeri. The results showed that the photoproduct toxicity increased after $240 \mathrm{~min}$ (from 60 to $84 \%$ inhibition of luminescence), then decreased to the minimum value after $360 \mathrm{~min}$ (35\% inhibition of luminescence). This result indicated that total mineralization of tetracycline produced photoproducts with lower toxicity than tetracycline (Bouafia-Chergui et al., 2016).

The main components of photocatalysis systems are the light source, the photocatalyst, and the polluted water (Sundar and Kanmani, 2020). AB degradation via photocatalysis follows five steps, as depicted in Figure 1: 1) diffusion of the organic pollutant from the bulk of the solution to the surface of the catalyst, 2) adsorption of the organic pollutant onto the surface of the catalyst, 3) degradation of the contaminants on the surface of the catalyst, 4) desorption of the resultant products from the surface of the photocatalyst, and 5) diffusion of the products from the surface of the semiconductor toward the bulk of the solution (Ibhadon and Fitzpatrick, 2013). After illumination by UV/visible light, the semiconductor (e.g., $\mathrm{TiO}_{2}$ ) molecules form unlinked pairs of electrons $\left(e^{-}\right)$/holes $\left(h^{+}\right)$due to the excitation of the electrons from the valence band (VB) to the conduction band (CB). These 
charge carriers may either return to the initial state in the semiconductor, or move to the surface of the catalyst to undergo various redox reactions with water molecules, hydroxide ions, and the pollutant. Figure 2 illustrates the mechanism of photocatalysis, and Eqs 1-6 define the chemical reactions. In these Equations, $\mathrm{TiO}_{2}$ represents the catalyst, $\left(\mathrm{e}^{-}\right)$represents the conduction band electron, and $\left(h^{+}\right)$represents the valence band hole (Zeghioud et al., 2016).

$$
\mathrm{TiO}_{2} \rightarrow{ }^{\mathrm{h} \vartheta} \mathrm{e}^{-}+h^{+}(\lambda \leq 380 \mathrm{~nm})
$$

The positive hole $\left(h^{+}\right)$can produce hydroxyl radicals via two paths. The first path is hole transfer to the water molecule; the second path is hole transfer to a hydroxyl ion (Eqs 2, 3, respectively) (Zeghioud et al., 2016).

$$
\begin{gathered}
h^{+}+\mathrm{H}_{2} \mathrm{O} \rightarrow \bullet \mathrm{OH}+\mathrm{H}^{+} \\
h^{+}+\mathrm{OH}^{-} \rightarrow \bullet \mathrm{OH}
\end{gathered}
$$

The positive hole $\left(h^{+}\right)$can also oxidize the antibiotic pollutants (P) in water (Eq. 4), followed by the formation of intermediates produced from reactions with the hydroxyl radicals (Eq. 5) (Zeghioud et al., 2016).

$$
h^{+}+P_{a d s} \rightarrow P_{a d s} .
$$

$\bullet \mathrm{OH}+\mathrm{P}_{\mathrm{ads}} \cdot \rightarrow$ intermediates/degradation products

- $\mathrm{OH}$ radicals also can react with water pollutants to cause mineralization into water and carbon dioxide (Eq. 6) (Zeghioud et al., 2016).

$$
\bullet \mathrm{OH}+\mathrm{P} \rightarrow \mathrm{H}_{2} \mathrm{O}+\mathrm{CO}_{2}+\text { inorganic acids }
$$

In the presence of molecular oxygen, the excited electrons interact with the adsorbed oxygen on the catalyst surface (Eq. 7) and produce superoxide radicals $\left(\mathrm{O}_{2}^{\bullet-}\right)$. These radicals are capable of preventing the recombination of the electrons with the positive holes (Zeghioud et al., 2016; Ibhadon and Fitzpatrick, 2013) and are converted to hydrogen peroxide and then to hydroxyl radicals as shown in the (Eqs 8-10) (Homem and Santos, 2011). Hydroxyl radicals play a significant role in the degradation of the organic pollutant.

$$
\begin{gathered}
\mathrm{O}_{2}+\mathrm{e}^{-} \rightarrow \mathrm{O}_{2}^{\bullet-} \\
\mathrm{O}_{2}^{\bullet-}+\mathrm{H}_{2} \mathrm{O} \rightarrow \mathrm{HO}_{2}^{\bullet}+\mathrm{OH}^{-} \\
2 \mathrm{HO}_{2}^{\bullet} \rightarrow \mathrm{H}_{2} \mathrm{O}_{2}+\mathrm{O}_{2} \\
\mathrm{H}_{2} \mathrm{O}_{2}+\mathrm{e}^{-} \rightarrow \mathrm{OH}^{-}+\bullet \mathrm{OH}
\end{gathered}
$$

Many factors influence the efficiency of the photocatalytic degradation of various organic pollutants in water, including the concentrations of the contaminant and the catalyst, the light source and its intensity, the solution $\mathrm{pH}$, the solution turbidity, the presence of other contaminants, and the type of photo-reactor employed (Saadati et al., 2016a). Increasing the initial AB or catalyst concentration increases the rate of degradation until reaching an optimal value, after which the degradation rate decreases (Saadati et al., 2016a). A suitable light source with an appropriate intensity and wavelength is essential to ensure optimum catalyst activation (Liu et al., 2013; Saadati et al., 2016a; Zhang et al., 2019). The effect of $\mathrm{pH}$ is a function of the operating conditions and the chemical nature of pollutants and catalyst. The capacity of the catalyst itself to harvest light photons and efficiently utilize the excited electrons in degrading the pollutant is a critical factor that affects system performance (Saadati et al., 2016a). The water turbidity also affects photocatalysis efficiency. For example, high water turbidity in the treated stream can reduce light transmission through the water into the catalyst's surface, thereby reducing light absorption by the catalyst and subsequent electron activation (Teoh et al., 2012; Divakaran et al., 2021). The presence of salts and other organic pollutants in the water may affect $\mathrm{AB}$ adsorption onto the catalyst surface, and can increase water turbidity. Ghoreishian et al. (Ghoreishian et al., 2021) compared the performance of Fe and $\mathrm{Sn}$ co-doped- $\mathrm{TiO}_{2}$ nanofibers for tetracycline degradation in synthetic, river, and tap water samples. The results showed that the highest efficiency was obtained for synthetic pure water (96.96\%), followed by tap water $(81.85 \%)$, and then river water (60.59\%). This result clearly indicates that photocatalyst performance can be overestimated by experiments that use pure water in laboratory settings.

The choice of photocatalytic reactor is a function of the reaction system, including the chemical structure and concentrations of pollutants and catalyst, the operating flowrate, temperature, and pressure (Ibhadon and Fitzpatrick, 2013). Slurry reactors are conventional reactors that suspend the heterogeneous photocatalysts in a liquid phase in the reactor. Heterogeneous photocatalysts are preferred over homogeneous photocatalysts in slurry reactors because they offer easier catalyst recovery and high efficiency. Accordingly, catalyst immobilization on solid substrates such as polymers, glass, sand, or reactor walls has been receiving great attention recently to achieve efficient catalyst recovery and sustainable system operation (Ibhadon and Fitzpatrick, 2013; Zeghioud et al., 2016).

\subsection{Photocatalytic Degradation of Tetracyclines}

Tetracyclines contamination of surface and ground water, hence eventually irrigation water, is due to the inefficient removal capacity of current conventional wastewater plants, leading to residual tetracycline concentrations of up to $2.37 \mu \mathrm{g} / \mathrm{L}$ in the final effluent stream released into the environment (Daghrir and Drogui, 2013). Photocatalytic degradation of tetracyclines using UV, visible, and solar light has been explored for complete tetracycline demineralization (Bouafia-Cherguı et al., 2016; Chen et al., 2016; Farhadian et al., 2019). Three primary photocatalytic systems have been extensively studied: semiconductor systems such as $\mathrm{TiO}_{2}$ (Zhu et al., 2013; Niu et al., 2014; Safari et al., 2014) and ZnO (Farhadian et al., 2019); binary composite systems such as $\mathrm{Ag}-\mathrm{Bi}_{2} \mathrm{WO}_{6}$, $\mathrm{Ag}$ $\mathrm{BiVO}_{4}-\mathrm{Cu}_{2} \mathrm{O}$, and $\mathrm{AgBr}-\mathrm{Ag}_{3} \mathrm{PO}_{4}$ (Deng et al., 2017; Shen et al., 2018; Yan et al., 2018; Rasheed et al., 2019); and heterojunctions such as $\mathrm{AgI} / \mathrm{WO}_{3}, \mathrm{CQDs} / \mathrm{Bi}_{2} \mathrm{WO}_{6}, \mathrm{C}_{3} \mathrm{~N}_{4} /$ $\mathrm{Bi}_{2} \mathrm{WO}_{6}$, and CQDS/ZnO (Di et al., 2015; Wang et al., 2016; Chen et al., 2017; Li J. et al., 2019).

Other common examples on materials used for tetracyclines photocatalytic degradation under both UV and visible light 
TABLE 4 | Previous work on tetracycline removal by $\mathrm{TiO}_{2}$ catalyst under UV light.

\begin{tabular}{|c|c|c|c|c|c|c|c|}
\hline$\#$ & Catalyst & $\begin{array}{c}\text { TC initial } \\
\text { concentration } \\
(\mathrm{mg} / \mathrm{L})\end{array}$ & $\begin{array}{c}\text { Catalyst } \\
\text { concentration }(g / L)\end{array}$ & UV light source & $\mathrm{pH}$ & $\begin{array}{l}\text { Removal } \\
\text { efficiency }\end{array}$ & Year and ref \\
\hline 1 & $\mathrm{TiO}_{2}$ P25 (Degussa) 20-30 nm & 40 & 1 & $\begin{array}{l}\text { UV: } 300 \mathrm{~W} \\
(290<\lambda<365) \text { mercury } \\
\text { lamp }\end{array}$ & 4.2 & $\begin{array}{l}95 \% \text { after } \\
60 \mathrm{~min}\end{array}$ & 2013 Zhu et al. (2013) \\
\hline 2 & $\begin{array}{l}\text { Commercially available } \mathrm{TiO}_{2} \\
\text { (BIOCHEM ChemoPharma) }\end{array}$ & 5 & 2 & UV: $12 \mathrm{~W}$ halogen lampa & Free & $\begin{array}{l}100 \% \text { after } \\
210 \text { min }\end{array}$ & $\begin{array}{l}2016 \text { Bouafia-Chergul et al. } \\
\text { (2016) }\end{array}$ \\
\hline 3 & $\begin{array}{l}\mathrm{TiO}_{2} \text { (US-Research } \\
\text { Nanomaterials) } 10-25 \mathrm{~nm}\end{array}$ & 15 & 2 & UV: $15 \mathrm{~W}^{\mathrm{a}}$ & 5 & $\begin{array}{c}100 \% \text { after } \\
45 \text { min }\end{array}$ & 2018 Fazilati et al. (2018) \\
\hline
\end{tabular}

a Light wavelength was not specified in the original paper.

Free $\mathrm{pH}$ : medium $\mathrm{pH}$ was not controlled.

include the application and modification of titania $\left(\mathrm{TiO}_{2}\right)$ semiconductors. In these studies, both high performance liquid chromatography (Wang et al., 2011; Cao et al., 2016) or UV-VIS spectrophotometer (Yu et al., 2014; Oseghe and Ofomaja, 2018a; Lyu et al., 2019; Ghoreishian et al., 2020) were used for the analysis of the water samples and for the evaluation of the degradation efficiency of the TCs over the investigated photocatalysts. Photocatalytic tetracycline degradation mediated by $\mathrm{TiO}_{2}$ is expected to proceed via the formation of intermediates, which eventually completely degrade into $\mathrm{CO}_{2}, \mathrm{H}_{2} \mathrm{O}$, and $\mathrm{NH}_{4}{ }^{+}$. Zhu et al. (Zhu et al., 2013) proposed that $\mathrm{TiO}_{2}$-mediated tetracycline degradation involved electron transfer, hydroxylation, open-ring reactions, and cleavage of the central carbon.

\section{3 $\mathrm{TiO}_{2}$-Based Photocatalysts for Tetracyclines Degradation}

$\mathrm{TiO}_{2}$ is the most studied and used heterogeneous photocatalyst semiconductor due to its super quantum yield (ratio of emitted photons to absorbed photons), low cost, non-toxicity, hydrophilicity, high photoactivity, interesting charge transport properties, and good chemical and photostability (Ibhadon and Fitzpatrick, 2013; Sommer et al., 2015; Koe et al., 2019; You et al., 2019; Zhang et al., 2019). $\mathrm{TiO}_{2}$ exists in three polymorphs/crystal forms: anatase, rutile, and brookite. Anatase and rutile forms of $\mathrm{TiO}_{2}$ are utilized as photocatalysts; however, anatase is preferred due to its superior quantum yield (Koe et al., 2019). A hybrid form of $\mathrm{TiO}_{2}$ called Degussa (Evonik-Degussa) P-25 consists of a phase-junction mixture of (25\%) rutile and (75\%) anatase. $\mathrm{TiO}_{2-}$ P25 is widely investigated for photodegradation of organic pollutants due to its availability, stability, reusability, and high oxidation activity compared to other crystal forms of $\mathrm{TiO}_{2}$ (Ibhadon and Fitzpatrick, 2013; Koe et al., 2019).

$\mathrm{TiO}_{2}$ has a band gap $\left(\mathrm{E}_{\mathrm{g}}\right)$ of approximately $3-3.2 \mathrm{eV}$, which limits its photoactivity to ultraviolet light with a wavelength less than $387 \mathrm{~nm}$ (Koe et al., 2019). Table 4 summarizes some applications of Titania for photodegradation of tetracyclines under UV light. In general, Titania achieves very high degradation efficiencies of (95-100\%) in relatively short periods of time (45-60 $\mathrm{min})$.

Despite its promising photocatalytic activities, Titania has some shortcomings that limit its wide application in photocatalysis. For example, due to its wide band gap energy
(3.2 eV) $\mathrm{TiO}_{2}$ can only be activated under UV light which only accounts for $(5 \%)$ of the solar spectrum. The recombination rate of the charge carriers is significantly high in $\mathrm{TiO}_{2}$, and this suppresses its $\mathrm{AB}$ degradation efficiency. $\mathrm{TiO}_{2}$ also undergoes agglomeration and aggregation which complicates its recovery and reuse in large-scale applications. Moreover, $\mathrm{TiO}_{2}$ has low adsorption capacity of nonpolar contaminants due to its polar nonporous surface (Bahadar Khan and Kalsoom, 2019; Li R. et al., 2020).

Further modification of Titania is urgently needed to achieve practical, visible light-induced photocatalytic applications. Many studies have been reported in the literature to enhance Titania properties through modification and/or combination with organic and/or inorganic counterparts (Wang et al., 2011; Chen et al., 2016; Pouretedal and Afshari, 2016; Zhang S. et al., 2017; Zhang F. J. et al., 2017; Chen and Liu, 2017; Jin et al., 2017; Duan et al., 2018; He et al., 2018; Tang et al., 2018; Zheng et al., 2018; Liu M. et al., 2019; Chen Y. et al., 2019; Farhadian et al., 2019; Galedari et al., 2019; Sun et al., 2019; Akel et al., 2020; Zhang T. et al., 2020; Ghoreishian et al., 2020; Liu et al., 2020; Divakaran et al., 2021; Ghoreishian et al., 2021). The following section presents a detailed summary of various methods reported in the literature to achieve visible light sensitization of Titania and its applications for tetracyclines photodegradation.

\section{MODIFICATION OF $\mathrm{TiO}_{2}$ FOR ENHANCED VISIBLE LIGHT ACTIVITY}

Researchers have studied $\mathrm{TiO}_{2}$ modification for more than 30 years to enhance its visible light photocatalytic properties, stability, and reusability using three primary modification methods: 1) hinder the recombination of excited electrons and positive holes; 2) expand titania activity from the UV light spectrum to include visible light (accounts for approximately (43\%) of the solar light spectrum) and ultimately solar light; and 3) enhance $\mathrm{TiO}_{2}$ morphology, surface area, and ease of recovery (Teoh et al., 2012). Recent advances in titania modification include doping with metals and nonmetals, developing hybrid composite systems, and constructing heterojunction photocatalysts ( $\mathrm{Li}$ and Shi, 2016). Each of 
TABLE 5 | Previous studies investigating tetracyclines removal by metal, nonmetal, and mixed metal-nonmetal doped $\mathrm{TiO}_{2}$ catalysts.

\begin{tabular}{|c|c|c|c|c|c|c|c|c|}
\hline$\#$ & $\begin{array}{l}\text { Modified } \\
\text { titania }\end{array}$ & $\begin{array}{c}\text { TC initial } \\
\text { concentration } \\
(\mathrm{mg} / \mathrm{L})\end{array}$ & $\begin{array}{c}\text { Catalyst } \\
\text { concentration }\end{array}$ & $\begin{array}{l}\text { Light } \\
\text { source }\end{array}$ & pH & $\begin{array}{c}\text { Results } \\
\text { with } \\
\text { doped } \\
\mathrm{TiO}_{2}\end{array}$ & $\begin{array}{c}\text { Results } \\
\text { with } \\
\text { pure } \\
\mathrm{TiO}_{2}\end{array}$ & $\begin{array}{l}\text { Year } \\
\text { and ref }\end{array}$ \\
\hline 1 & Co-doped $\mathrm{TiO}_{2}$ & $30 \mathrm{Oxy}-(\mathrm{TCH})$ & $0.5 \mathrm{~g} / \mathrm{L}$ & UV/vis illumination ${ }^{\mathrm{a}}$ & 5 & $\begin{array}{l}98 \% \text { after } \\
60 \text { min }\end{array}$ & $97 \%$ after $60 \mathrm{~min}$ & 2020 Akel et al. (2020) \\
\hline 2 & $\mathrm{Zr} / \mathrm{Sn}$ co-doped $\mathrm{TiO}_{2}$ & 20 (TC) & $0.8 \mathrm{~g} / \mathrm{L}$ & $\begin{array}{l}36 \mathrm{~W} \text { mercury low } \\
\text { pressure lamp }^{\mathrm{a}}\end{array}$ & 3 & $\begin{array}{l}100 \% \text { after } \\
180 \mathrm{~min}\end{array}$ & $79 \%$ after $180 \mathrm{~min}$ & $\begin{array}{l}2015 \text { Pouretedal and } \\
\text { Afshari, (2016) }\end{array}$ \\
\hline 3 & $\mathrm{Fe} / \mathrm{Sn}$ co-doped $\mathrm{TiO}_{2}$ & 30 (TC) & $0.3 \mathrm{~g} / \mathrm{L}$ & $\begin{array}{l}300 \mathrm{~W} \text { Xenon }(\mathrm{Xe}) \text { arc } \\
\text { lamp }(\lambda>420 \mathrm{~nm})\end{array}$ & 6 & $\begin{array}{l}96.96 \% \text { after } \\
60 \text { min }\end{array}$ & $5 \%$ after $60 \mathrm{~min}$ & $\begin{array}{l}2021 \text { Ghoreishian et al. } \\
\text { (2021) }\end{array}$ \\
\hline 4 & $\begin{array}{l}\mathrm{H}_{2} \mathrm{O}_{2} \text { modified } \mathrm{Zn}- \\
\text { doped } \mathrm{TiO}_{2}\end{array}$ & 80 (TC) & $1 \mathrm{~g} / \mathrm{L}$ & 500 W Xe lampa & 7 & $\begin{array}{l}88.14 \% \text { after } \\
360 \text { min }\end{array}$ & $70 \%$ after $360 \mathrm{~min}$ & 2016 Pang et al. (2016) \\
\hline 5 & $\mathrm{Y}^{3+} / \mathrm{TiO}_{2} \mathrm{Hal}-\mathrm{PMPD}$ & $50(\mathrm{TC})$ & $2 \mathrm{~g} / \mathrm{L}$ & $\begin{array}{l}500 \mathrm{~W} \text { Xe lamp }(\lambda> \\
380 \mathrm{~nm})\end{array}$ & 1 & $\begin{array}{l}78.8 \% \text { after } \\
50 \mathrm{~min}\end{array}$ & - & 2014 Yu et al. (2014) \\
\hline 6 & $\begin{array}{l}\text { Phosphorous-doped } \\
\text { anatase } \mathrm{TiO}_{2}\end{array}$ & $60(\mathrm{TCH})$ & $0.5 \mathrm{~g} / \mathrm{L}$ & $\begin{array}{l}500 \text { W halogen-tungsten } \\
\text { lamp }^{a}\end{array}$ & 7 & $\begin{array}{l}93 \% \text { after } \\
120 \text { min }\end{array}$ & $\begin{array}{l}62 \% \text { after } 120 \mathrm{~min} \\
\text { (anatase) }\end{array}$ & 2014 Niu et al. (2014) \\
\hline 7 & C-N-S tri-doped $\mathrm{TiO}_{2}$ & $5(\mathrm{TC})$ & $0.5 \mathrm{~g} / \mathrm{L}$ & $\begin{array}{l}6 \mathrm{~W}(\mathrm{~F} 6 \mathrm{~T} 5 / \mathrm{D}) \text { cold white } \\
\text { visible lamp }(\lambda>420 \mathrm{~nm})\end{array}$ & 9 & $\begin{array}{l}95 \% \text { after } \\
180 \text { min }\end{array}$ & $25 \%$ after $180 \mathrm{~min}$ & 2011 Wang et al. (2011) \\
\hline 8 & $\begin{array}{l}\mathrm{TiO}_{2} \text { doped with } \\
\text { acetylene black }\end{array}$ & $10(\mathrm{TCH})$ & $0.5 \mathrm{~g} / \mathrm{L}$ & $\begin{array}{l}30 \text { W LED lamp }(400<\lambda< \\
780 \mathrm{~nm})\end{array}$ & 4.1 & $\begin{array}{l}93.3 \% \text { after } \\
120 \mathrm{~min}\end{array}$ & $20 \%$ after $120 \mathrm{~min}$ & $\begin{array}{l}2020 \text { Zhang T. et al. } \\
\text { (2020) }\end{array}$ \\
\hline 9 & $\mathrm{~N}$-doped $\mathrm{TiO}_{2}$ & $10(\mathrm{TC})$ & $0.2 \mathrm{~g} / \mathrm{L}$ & Visible light $(\lambda=420 \mathrm{~nm})$ & 7 & $\begin{array}{l}90 \% \text { after } \\
120 \text { min }\end{array}$ & $73 \%$ after $120 \mathrm{~min}$ & 2020 Wu et al. (2020) \\
\hline 10 & $\begin{array}{l}\text { Porous N, S co- } \\
\text { doped } \mathrm{TiO}_{2}\end{array}$ & 20 (TC) & $0.4 \mathrm{~g} / \mathrm{L}$ & $\begin{array}{l}300 \mathrm{~W} \text { Xe lamp }(\lambda> \\
420 \mathrm{~nm})\end{array}$ & Free & $\begin{array}{l}84.9 \% \text { after } \\
60 \text { min }\end{array}$ & $\begin{array}{l}\text { Comparable results } \\
\text { as modified }\end{array}$ & $\begin{array}{l}2020 \text { Ouyang and Ji, } \\
\text { (2020) }\end{array}$ \\
\hline 11 & $\begin{array}{l}(\mathrm{Sn}, \mathrm{Zn}) \text { and } \mathrm{N} \text { co- } \\
\text { doped } \mathrm{TiO}_{2}\end{array}$ & 35 (TC) & $0.5 \mathrm{~g} / \mathrm{L}$ & $\begin{array}{l}\text { Simulated solar } \\
\text { irradiation }^{\mathrm{a}}\end{array}$ & 7 & $\begin{array}{l}33 \% \text { after } \\
120 \text { min }\end{array}$ & $22 \%$ after $120 \mathrm{~min}$ & 2018 Rimoldi et al. (2018) \\
\hline
\end{tabular}

aLight wavelength was not specified in the original paper.

Free $\mathrm{pH}$ : medium $\mathrm{pH}$ was not controlled.

Abbreviations: TC, tetracycline; $\mathrm{TCH}$, tetracycline hydrochloride.

these Titania modification methods is discussed in the following sections.

\subsection{Metal and Nonmetal Doping of $\mathrm{TiO}_{2}$}

Doping is the introduction of a metallic and/or nonmetallic element (dopant) into the bulk of a semiconductor without modifying its structure or altering its crystallographic form (Teoh et al., 2012; Ibhadon and Fitzpatrick, 2013). The presence of the dopant results in a large dipole moment that can alter the kinetics of the electron transfer process. It lowers the band gap energy and widens the light absorption spectrum by increasing the number of migrating electrons from the valence band to the conduction band of the main semiconductor (Koe et al., 2019). Consequently, optimal doping conditions enable photocatalyst activation under UV and visible light $(380 \mathrm{~nm}<\lambda<500 \mathrm{~nm})$ (Ibhadon and Fitzpatrick, 2013). Studies have investigated various dopants for the visible light sensitization of titania, including metal, nonmetal, or mixed metal-nonmetal doping (Li and Shi, 2016). The development of optimum doping conditions must consider the preparation method, the dopant concentration, and the type of dopant to ensure enhanced photocatalytic performance (Marschall and Wang, 2014). Table 5 presents examples of the best performing metal, nonmetal, and mixed metal-nonmetal doping of $\mathrm{TiO}_{2}$ photocatalysts and their performance in tetracyclines photodegradation under visible light.

\subsubsection{Metal lon Doping of $\mathrm{TiO}_{2}$}

Metal ion dopants of Titania include transition, rare earth, and precious metal ions. Metal doping of Titania is achieved by firing at high temperature or auxiliary deposition techniques (Zhang et al., 2019). Figure 3 illustrates the mechanisms of tetracyclines degradation by metal-doped $\mathrm{TiO}_{2}$ photocatalysts. Under visible light, electrons in the band gap energy of the doping metal are excited into the metal conduction band, and then move into the conduction band of the bulk catalyst. Simultaneously, Titania electrons are excited by the UV light of the solar light spectrum (Eq. 1). Consequently, these electron/hole pairs lead to a series of oxidationreduction reactions that produce oxygen and hydroxyl radicals (Eqs 2, 3, 7, 8, 9, 10) which in turn degrade the $\mathrm{AB}$ molecules (Eqs 4, 5, 6). An example of an efficient transition metal-doped Titania is cobalt (Co)-doped $\mathrm{TiO}_{2}$, which has been used with and without immobilization on reduced graphene oxide surfaces for tetracycline and oxytetracycline removal, respectively (Jamali Alyani et al., 2019; Akel et al., 2020). Cobalt-doped Titania was prepared using the reflux method $\left(\mathrm{Co}-\mathrm{TiO}_{2}-\mathrm{R}\right)$ by Akel et al. (Akel et al., 2020), and resulted in $(98 \%)$ degradation of oxytetracycline hydrochloride (Oxy-TCH) under UV-visible light illumination. The authors attributed the high initial rate of $\mathrm{Co}-\mathrm{TiO}_{2}-\mathrm{R}$ to its high surface area and enhanced charge transfer and separation properties imposed by impurity levels in the band gap energy; the Co particles entrapped some of the generated $\left(h^{+}\right)$, thereby minimizing the possibility of electron/hole recombination.

Metal co-doping was recently used to enhance visible light harvesting in $\mathrm{TiO}_{2}$ catalysts. Co-doping resulted in higher visible light activity than that resulting from single-doping due to a 


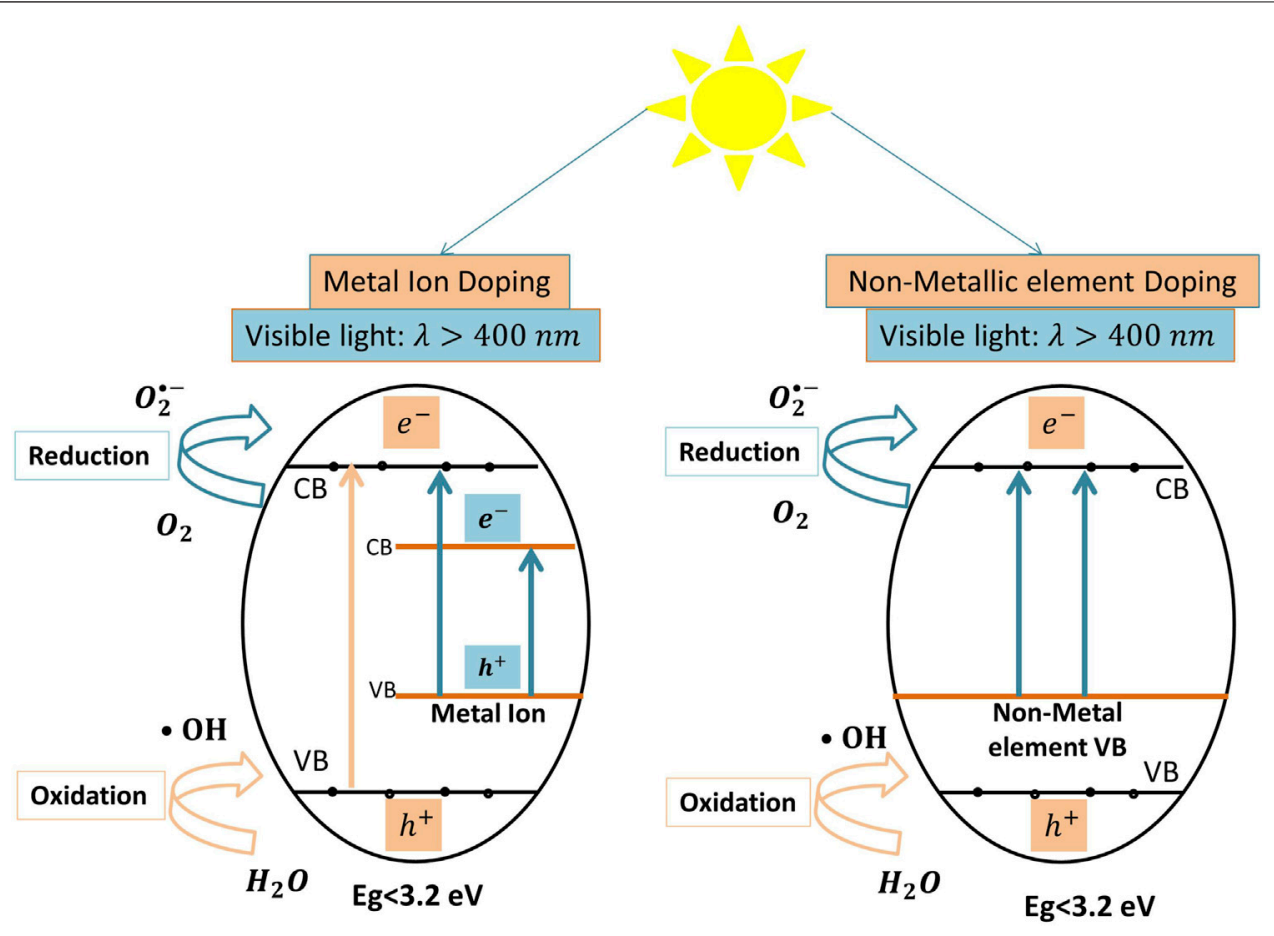

FIGURE 3 | The proposed photocatalytic degradation mechanisms of tetracycline both by metal-doped and non-metal doped $\mathrm{TiO}_{2}$ systems under visible light.

synergistic effect between the two dopants (You et al., 2019). Recent studies investigated bimetallic doping of $\mathrm{TiO}_{2}$ for tetracyclines degradation using zirconium $(\mathrm{Zr})$ and tin $(\mathrm{Sn})$ (Pouretedal and Afshari, 2016), and iron (Fe) and tin (Sn) (Ghoreishian et al., 2021). Ghoreishian et al. (Ghoreishian et al., 2021) developed highly efficient $\mathrm{Fe}$-Sn co-doped $\mathrm{TiO}_{2}$ nanofibers $\left(\mathrm{Fe} / \mathrm{Sn}-\mathrm{TiO}_{2} \mathrm{NFs}\right) . \mathrm{Fe} / \mathrm{Sn}-\mathrm{TiO}_{2} \mathrm{NFs}$ were produced using the electrospinning method, and then used for tetracycline degradation under $300 \mathrm{~W}$ xenon (Xe) lamp as the visible light source (Ghoreishian et al., 2021). This co-doped $\mathrm{TiO}_{2}$ catalyst displayed a very high photocatalytic degradation efficiency (96.96\%), which was $1.86,1.8$, and 1.56 times higher than the efficiencies of unmodified $\mathrm{TiO}_{2}, \mathrm{Fe}$-doped $\mathrm{TiO}_{2}$, and Sn-doped $\mathrm{TiO}_{2}$, respectively. The authors attributed the enhanced performance of the co-doped catalyst to its small crystal size, tunable and low band gap energy, higher adsorption capability, better visible light absorption, enhanced charge carrier separation, and suppressed charge carrier recombination. This co-doped catalyst also displayed high stability and maintained (92\%) degradation efficiency after five cycles of use. Total organic carbon (TOC) analysis was used to assess the extent of $\mathrm{AB}$ mineralization achieved by the catalyst. The $\mathrm{Fe} / \mathrm{Sn}-\mathrm{TiO}_{2} \mathrm{NFs}$ achieved (98\%) tetracycline mineralization, compared to only (56\%) tetracycline mineralization by the unmodified $\mathrm{TiO}_{2}$ catalyst.

\subsubsection{Nonmetal Doping of $\mathrm{TiO}_{2}$}

Nonmetal doping has been investigated for the visible light activation of $\mathrm{TiO}_{2}$ (Farhadian et al., 2019; Niu et al., 2014; Oseghe and Ofomaja, 2018a; Tang et al., 2018; Chen and Liu,
2016; Wu et al., 2020; Fang et al., 2019; Oseghe and Ofomaja, 2018b). Nonmetal-doped photocatalysts display higher stability and better photoactivity than metal-doped photocatalysts because metal-doping of $\mathrm{TiO}_{2}$ can, for example in some applications, lower the doped catalyst stability, reduce its activity, and decrease its photo-quantum efficiency due to rapid recombination of the electrons and the holes (Teoh et al., 2012). Nonmetal dopants of $\mathrm{TiO}_{2}$ include nitrogen (N) (Farhadian et al., 2019; Wang et al., 2011; Tang et al., 2018; Chen and Liu, 2016; Wu et al., 2020), sulfur (S) (Wang et al., 2011), carbon (C) (Zhang T. et al., 2020), and phosphorous (P) (Niu et al., 2014). Nonmetal doping is performed by creating mid-gap energy levels between the valence and conduction bands of the parent catalyst (Zhang et al., 2019; Ibhadon and Fitzpatrick, 2013; Radwan et al., 2018). The nonmetal dopant can enhance the visible light-induced photocatalytic activity of the catalyst because electrons in the newly created energy level can be excited by visible light into the conduction band of the bulk catalyst (Eq. 1). Eventually, these excited electrons settle on the surface of the doped catalyst and generate active radicals via redox reactions (Eqs 2, 3, 7, 8, 9, 10), which consequently attack and mineralize the $\mathrm{AB}$ molecules (Eqs 4, 5, 6) (Ibhadon and Fitzpatrick, 2013; Radwan et al., 2018). Importantly, the nonmetal dopant inhibits the recombination of the charge carriers, due to electron entrapment by the oxygen vacancies created in the catalyst (Feng et al., 2018; Basavarajappa et al., 2020). Figure 3 illustrates the mechanism of tetracyclines degradation by nonmetal-doped $\mathrm{TiO}_{2}$ systems.

Nitrogen is the most-studied nonmetal dopant for enhancing the visible light activity of $\mathrm{TiO}_{2}$ (Marschall and Wang, 2014). 
There are several methods to produce $\mathrm{N}$-doped $\mathrm{TiO}_{2}$, including hydrothermal, microemulsion, chemical vapor deposition, solvothermal, sol-gel, electrospinning, anodic oxidation, sputtering, ball milling, atomic layer deposition, and microwave (Basavarajappa et al., 2020). Several studies have produced $\mathrm{N}$-doped $\mathrm{TiO}_{2}$ for tetracyclines degradation under visible light (Wang et al., 2011; Chen and Liu, 2016; Tang et al., 2018; Farhadian et al., 2019; Wu et al., 2020). Wu et al. prepared $\mathrm{N}$-doped $\mathrm{TiO}_{2}-\mathrm{P} 25$ by treating $\mathrm{TiO}_{2}-\mathrm{P} 25$ with $\mathrm{NH}_{3}$ gas flow at $500^{\circ} \mathrm{C}$, and applied the catalyst for tetracycline degradation under visible light $(\lambda=420)$. This $\mathrm{N}$-doped $\mathrm{TiO}_{2^{-}}$ P25 displayed higher visible light sensitivity and enhanced photocatalytic performance due to the increased numbers of excited reactive electrons and holes. The authors confirmed that the presence of $\mathrm{N}$ in $\mathrm{TiO}_{2}$ created oxygen vacancies that entrapped the photoexcited electrons, thereby minimizing their recombination effect. The $\mathrm{N}$-doped $\mathrm{TiO}_{2}-\mathrm{P} 25$ tetracycline degradation performance (90\%) was higher than that of the unmodified $\mathrm{TiO}_{2}$ (73\%), and the doped photocatalyst maintained its stability and degradation efficiency for four consecutive cycles (Wu et al., 2020).

Carbon doping of Titania extends its light absorption into the visible region by acting as a sensitizer or by creating interstitial gap states in the catalyst structure (Palanivelu et al., 2007; Wu et al., 2013). Carbon doping also increases the number of photogenerated charge carriers that degrade organic pollutants in water (Palanivelu et al., 2007). Acetylene black-doped (AcB) and persulfate (PS)-employed $\mathrm{TiO}_{2}\left(\mathrm{TiO}_{2} / \mathrm{AcB} / \mathrm{PS}\right.$ was prepared using the sol-gel method (Zhang T. et al., 2020). Acetylene black lowered the band gap energy of $\mathrm{TiO}_{2}$ from 3.17 to $2.78 \mathrm{eV}$, thereby enabling it to be activated under visible light, efficiently minimizing charge carrier recombination, and promoting charge carrier separation. The $\mathrm{TiO}_{2} / \mathrm{AcB} / \mathrm{PS}$ photocatalyst displayed (93\%) tetracycline hydrochloride degradation efficiency, which was higher than that of unmodified $\mathrm{TiO}_{2}$ (20\%), and maintained high degradation efficiency (85\%) after five uses (Zhang T. et al., 2020).

Phosphorus (P) doping of $\mathrm{TiO}_{2}$ enhances the catalytic photoactivity by effectively suppressing charge carrier recombination due to electron entrapment by the oxygen vacancies created in the catalyst (Feng et al., 2018). The presence of a $\mathrm{P}$ dopant on $\mathrm{TiO}_{2}$ decreased its band gap energy and significantly enhanced its visible light-induced photocatalytic degradation of organic pollutants (Gopal et al., 2012). Niu et al. (Niu et al., 2014) used the rapid microwave hydrothermal method to prepare P-doped anatase $\mathrm{TiO}_{2}$ for tetracycline hydrochloride degradation under $500 \mathrm{~W}$ halogentungsten lamp. This $\mathrm{P}$-doped $\mathrm{TiO}_{2}$ displayed (93\%) tetracycline degradation efficiency, which was much higher than that of commercial $\mathrm{TiO}_{2}-\mathrm{P} 25$ (62\%).

Nonmetal element co-doping of $\mathrm{TiO}_{2}$ has gained enormous interest lately because of its potential to alter the photocatalytic characteristics of the catalyst, such as reducing the band gap energy and enhancing visible light absorption as compared to that of the single-element-doped catalyst (Chen et al., 2007). Co-doping and tri-doping were applied to $\mathrm{TiO}_{2}$ for enhanced tetracycline degradation. Wang et al. (Wang et al., 2011) used the sol-gel method to prepare C-N-S tri-doped $\mathrm{TiO}_{2}$ for tetracycline degradation under $6 \mathrm{~W}$ white visible light lamp. The C-N-S tri-doped $\mathrm{TiO}_{2}$ exhibited enhanced degradation performance (95\%) compared to that of unmodified $\mathrm{TiO}_{2}$ (25\%). The authors ascribed this improvement to the high surface area of the modified catalyst, the formation of a well-defined $\mathrm{TiO}_{2}$ anatase phase, the red shift of the light absorption spectrum of $\mathrm{TiO}_{2}$, the enhanced visible light sensitivity because of the narrowed band gap energy of $\mathrm{TiO}_{2}$, and the existence of carbon behaving as photosensitizer of $\mathrm{TiO}_{2}$, which led to synergistic enhancement of tetracycline adsorption.

\subsubsection{Mixed Metal-Nonmetal Doping of $\mathrm{TiO}_{2}$}

Mixed metal-nonmetal doping enables optimization of the advantages and minimization of the disadvantages of each doping method. This hybrid method specifically enhances the catalyst photo-efficiency by broadening the photo-activated spectrum toward the visible range. The $\mathrm{N}-\mathrm{TiO}_{2}$ catalyst is most commonly used for tetracyclines degradation under visible light, along with other nonmetal-doped $\mathrm{TiO}_{2}$ in mixed doping systems (Huo et al., 2016; Chen and Liu, 2017; Rimoldi et al., 2018; Chen Y. et al., 2019; Ghoreishian et al., 2020). Rimoldi et al. (Rimoldi et al., 2018) used the sol-gel method to prepare Sn-, $\mathrm{Zn}$-, and $\mathrm{N}$-doped $\mathrm{TiO}_{2}$ for tetracycline degradation under simulated solar irradiation. The authors reported that metal co-doping of $\mathrm{N}$-doped $\mathrm{TiO}_{2}$ induced a further red-shift in the light spectrum (400-600 nm). They attributed this improvement to the generation of intra-gap states in the $\mathrm{TiO}_{2}$ structure by the introduction of some defects caused by $\mathrm{Sn}$-doping. $\mathrm{TiO}_{2}-\mathrm{N}$ was reported to have quasi-spherical crystallites of high crystallinity and corresponding inter-planar distances of anatase $\mathrm{TiO}_{2}$. For $\mathrm{TiO}_{2}-\mathrm{N}-\mathrm{Sn}$ crystalline particles $(3-6 \mathrm{~nm})$ were detected along with the corresponding inter-planar distances of anatase and brookite $\mathrm{TiO}_{2}$ and small content of $\mathrm{SnO}_{2}$ cassiterite. In the $\mathrm{TiO}_{2}$ $\mathrm{NZn}$, the presence of $\mathrm{Zn}$ resulted in the formation of a guest phase of $\mathrm{ZnO}$ wurtzite. Particularly, $\mathrm{Zn}$ doping resulted in better photocatalytic performance due to its low crystallinity, unique amorphous structure, and high surface area as compared to the Sn-doping alone. The mixed metal-nonmetal $\mathrm{Zn} / \mathrm{Sn} / \mathrm{N}$-doped $\mathrm{TiO}_{2}$ exhibited (33\%) tetracycline degradation efficiency compared to $(22 \%)$ tetracycline degradation efficiency of the unmodified $\mathrm{TiO}_{2}$. This significant increase was attributed to the synergistic effect of the dopants, their ability to widen the light absorption spectrum, and the higher surface area of the catalyst. Although (33\%) tetracycline degradation efficiency is relatively low, the selected metal-nonmetal pairs and their concentrations can be optimized to improve photocatalyst performance.

In general, co- or tri-doping of $\mathrm{TiO}_{2}$ can overcome some of the drawbacks of single doping, and enhance catalyst performance and stability in tetracyclines degradation due to the synergistic effect among the dopants. The choice of the dopant should consider its cost, toxicity, doping conditions, and preparation method. The dopant concentration also needs to be optimized to ensure enhanced performance of the final catalyst (Marschall and Wang, 2014). 
TABLE 6 | Examples of titania-based composites and their tetracyclines degradation efficiencies.

\begin{tabular}{|c|c|c|c|c|c|c|c|c|}
\hline \# & $\begin{array}{l}\text { Modified } \\
\text { titania }\end{array}$ & $\begin{array}{c}\text { Tetracycline } \\
\text { initial } \\
\text { concentration } \\
\text { (mg/L) }\end{array}$ & $\begin{array}{c}\text { Catalyst } \\
\text { concentration }\end{array}$ & $\begin{array}{l}\text { Light } \\
\text { source }\end{array}$ & pH & $\begin{array}{c}\text { Removal } \\
\% \text { by } \\
\mathrm{TiO}_{2} \text {-Based } \\
\text { composite } \\
\text { catalysts }\end{array}$ & $\begin{array}{c}\text { Removal } \\
\text { \% by } \\
\text { unmodified } \\
\text { TiO2 }\end{array}$ & $\begin{array}{l}\text { Year } \\
\text { and ref }\end{array}$ \\
\hline
\end{tabular}

A. Immobilized titania composites

1 Chitosan modified N-, S-doped

$\mathrm{TiO}_{2}$

2 2D sandwich-like $\mathrm{TiO}_{2}-\mathrm{rGO}$ composite

$3 \quad \mathrm{Fe}_{2} \mathrm{O}_{3}-\mathrm{TiO}_{2}$-modified zeolite composites

$4 \mathrm{~N}$-doped $\mathrm{TiO}_{2} / \mathrm{rGO}$

$5 \mathrm{Ce} / \mathrm{N}$ co-doped $\mathrm{TiO}_{2} / \mathrm{NiFe}_{2} \mathrm{O}_{4} /$ diatomite

6 Floating $\mathrm{Fe} / \mathrm{N}$ co-doped $\mathrm{TiO}_{2} /$ diatomite

7 Zn-doped $\mathrm{TiO}_{2}$ nanoparticles/GO

8 Cobalt-doped $\mathrm{TiO}_{2}$ nanosheets/rGO

$9 \mathrm{~N}$-doped $\mathrm{TiO}_{2} /$ diatomite

10 Black $\mathrm{TiO}_{2}$ nanoparticle/ porous carbon

$11 \mathrm{Fe}_{3} \mathrm{O}_{4} / \mathrm{rGO} / \mathrm{TiO}_{2}$ nanocomposites

12 Silver/ $/ \mathrm{TiO}_{2}$ nanosheets/rGO

13 Ce-doped $\mathrm{TiO}_{2}-\mathrm{MGO}$ hybrid photocatalyst

$14 \mathrm{TiO}_{2} /$ Semnan natural zeolite

15 Ce-doped $\mathrm{TiO}_{2}$ /halloysite nanotubes

$16 \mathrm{Au}_{-} \mathrm{TiO}_{2} /$ polydopamine (pDA)coated PVDF

17 Bimetallic Au- and Ag-doped $\mathrm{TiO}_{2}$ nanorods/cellulose acetate polymethylsilsesquioxane aerogels
30 (TC)

25 (TC)

8 (TC)

$10(\mathrm{TC})$
$20(\mathrm{TCH})$
20 Oxy-(TC)
$10(\mathrm{TCH})$
$20(\mathrm{TC})$
$10(\mathrm{TC})$
$40(\mathrm{TC})$
$20 \mathrm{Oxy}-(\mathrm{TCH})$
$20(\mathrm{TCH})$
$50(\mathrm{TC})$

$0.6 \mathrm{~g} / \mathrm{L}$

Visible light ${ }^{a}$

20 (TC)

10 (TC)

5 (TC)

$10(\mathrm{TCH})$
$0.75 \mathrm{~g} / \mathrm{L}$

Halogen 500 W lamp $(350<\lambda<$ $800 \mathrm{~nm})$

$0.4 \mathrm{~g} / \mathrm{L}$

$1 \mathrm{~g} / \mathrm{L}$

$1 \mathrm{~g} / \mathrm{L}$

$0.5 \mathrm{~g} / \mathrm{L}$

$5 \mathrm{~g} / \mathrm{L}$

$1 \mathrm{~g} / \mathrm{L}$

$1 \mathrm{~g} / \mathrm{L}$

$5 \mathrm{~g} / \mathrm{L}$

$0.6 \mathrm{~g} / \mathrm{L}$

$0.4 \mathrm{~g} / \mathrm{L}$

$420 \mathrm{~nm}$ )

150 W Xe lamp ${ }^{a}$

Xenon (Xe) lampa

$200 \mathrm{~W} \lambda=$

$455 \mathrm{~nm}$ LED light

$150 \mathrm{~W}$ Xe lamp

$(\lambda>400 \mathrm{~nm})$

(filter to isolate

UV light) ${ }^{a}$

500 W Xe lamp ${ }^{\mathrm{a}} \quad$ Free

$500 \mathrm{~W}$ halogen Free lamp $(350<\lambda<$

$800 \mathrm{~nm})$

Xe lampa

300 W Xe lamp

$0.5 \mathrm{~g} / \mathrm{L}$

$0.8 \mathrm{~g} / \mathrm{L}$

$60 \mathrm{~W}$ visible

lampa $^{a}$

$0.5 \mathrm{~g} / \mathrm{L}$

$300 \mathrm{~W}$ Xe lamp

$(\lambda>420 \mathrm{~nm})$

- $\quad 300 \mathrm{~W}$ Xe lamp

$(\lambda>420 \mathrm{~nm})$

Fixed on a

membrane

Xe lamp $(\lambda>$

$420 \mathrm{~nm})$

$10 \mathrm{~g} / \mathrm{L}$

Visible light $(\lambda>$ $(\lambda>400 \mathrm{~nm})$ $420 \mathrm{~nm}$ )

\subsection{2\% after $50 \mathrm{~min}$}

5.2

$96 \%$ after

120 min

Free $\quad 98 \%$ after $60 \mathrm{~min}$

$7 \quad 98 \%$ after 60 min

$7 \quad 100 \%$ after

$180 \mathrm{~min}$

$96.5 \%$ after

150 min

98.5\% after

$120 \mathrm{~min}$

$68 \%$ after

$180 \mathrm{~min}$

93\% after

$300 \mathrm{~min}$

$90 \%$ after

$160 \mathrm{~min}$

$92.6 \%$ after

$330 \mathrm{~min}$ in the

presence of $\mathrm{H} 2 \mathrm{O} 2$

$52.56 \%$ after

$180 \mathrm{~min}$

82.92\% after

$60 \mathrm{~min}$
$87 \%$ after $90 \mathrm{~min}$

$78 \%$ after 60 min

$92 \%$ after

120 min

90\% after

120 min

$98 \%$ after

$180 \mathrm{~min}$
2019 Farhadian et al.

(2019)

2017 Zhang S. et al.

$28 \%$ after

(2017)

- $\quad 2019$ Liu M. et al. (2019)

$10 \%$ after

60 min

$-$

(2017)

- 2019 Chen Y. et al.

(2019)

$20 \%$ after

$120 \mathrm{~min}$

2017 Zhang F. J. et al.

(2017)

2019 Jamali Alyani et al.

(2019)

2016 Chen and Liu,

(2016)

- $\quad 2019$ Fang et al. (2019)

- $\quad 2017$ Wang W. et al. (2017)

- $\quad 2020$ Tabatabai-Yazdi et al. (2020)

10.9\% after 2016 Cao et al. (2016)

$60 \mathrm{~min}$

$10 \%$ after

90 min

2016 Saadati et al.

(2016b)

8\% after 60 min 2019 Wang et al. (2019)

- $\quad 2017$ Wang C. et al.

(2017)

- $\quad 2019$ Li W. et al. (2019)

- $\quad 2021$ Xu H. et al. (2021)

B. Nanostructured Titania Composites

\begin{tabular}{|c|c|c|c|c|c|c|c|c|}
\hline 19 & $\begin{array}{l}\mathrm{TiO}_{2} \text { nanobelts modified by } \mathrm{Au} \\
\text { and CuS nanoparticles }\end{array}$ & 5 Oxy-(TC) & $4 \mathrm{~cm}^{2}$ & $\begin{array}{l}\text { Simulated solar } \\
\text { light, a } 35 \text { W Xe } \\
\text { lampa }^{\text {a }}\end{array}$ & 7 & $96 \%$ after 60 min & $\begin{array}{c}48 \% \text { after } \\
60 \text { min by } \mathrm{TiO}_{2} \\
\text { nanobelts }\end{array}$ & 2016 Chen et al. (2016) \\
\hline 20 & $\begin{array}{l}\mathrm{TiO}_{2} \text { doped with acetylene } \\
\text { black }\end{array}$ & $10(\mathrm{TCH})$ & $0.5 \mathrm{~g} / \mathrm{L}$ & $\begin{array}{l}30 \text { W LED lamp } \\
(\lambda \text { 400-780 nm) }\end{array}$ & 4.1 & $\begin{array}{l}93.3 \% \text { after } \\
120 \mathrm{~min}\end{array}$ & $\begin{array}{c}20 \% \text { after } \\
120 \mathrm{~min}\end{array}$ & $\begin{array}{l}2020 \text { Zhang T. et al. } \\
\text { (2020) }\end{array}$ \\
\hline 21 & $\begin{array}{l}\text { (1D) } \mathrm{MIL}-100(\mathrm{Fe}) / \mathrm{TiO}_{2} \\
\text { nanoarrays }\end{array}$ & 100 (TC) & Film sample & $450 \mathrm{~W}$ Xe lamp ${ }^{a}$ & Free & $\begin{array}{l}90.79 \% \text { after } \\
60 \text { min }\end{array}$ & $\begin{array}{l}35.22 \% \text { after } \\
60 \mathrm{~min}\end{array}$ & 2018 He et al. (2018) \\
\hline 22 & $\mathrm{Ag} / \mathrm{AgBr}-$ modified $\mathrm{TiO}_{2}$ & 10 (TC) & $1.2 \mathrm{~g} / \mathrm{L}$ & $\begin{array}{l}\text { 5W LED white } \\
\text { lamp }^{a}\end{array}$ & 4.5 & $\begin{array}{l}95.3 \% \text { after } \\
60 \mathrm{~min}\end{array}$ & $\begin{array}{l}20 \% \text { after } \\
60 \mathrm{~min}\end{array}$ & 2019 Sun et al. (2019) \\
\hline 23 & $\mathrm{TiO}_{2}-\mathrm{Fe}_{2} \mathrm{O}_{3}$ & 15 (TC) & $0.75 \mathrm{~g} / \mathrm{L}$ & $60 \mathrm{~W}$ lamp $^{\mathrm{a}}$ & 4.7 & $93 \%$ after $90 \mathrm{~min}$ & - & $\begin{array}{l}2019 \text { Galedari et al. } \\
\text { (2019) }\end{array}$ \\
\hline 24 & Carbon-modified $\mathrm{TiO}_{2}$ & $5(\mathrm{TCH})$ & $0.3 \mathrm{~g} / \mathrm{L}$ & $\begin{array}{l}\text { White LED }(\lambda= \\
450 \mathrm{~nm})\end{array}$ & 7 & $\begin{array}{l}73.53 \% \text { after } \\
120 \mathrm{~min}\end{array}$ & $\begin{array}{l}40 \% \text { after } \\
120 \text { min }\end{array}$ & $\begin{array}{l}2018 \text { Oseghe and } \\
\text { Ofomaja, (2018b) }\end{array}$ \\
\hline
\end{tabular}


TABLE 6 | (Continued) Examples of titania-based composites and their tetracyclines degradation efficiencies.

\begin{tabular}{|c|c|c|c|c|c|c|c|c|}
\hline$\#$ & $\begin{array}{l}\text { Modified } \\
\text { titania }\end{array}$ & $\begin{array}{c}\text { Tetracycline } \\
\text { initial } \\
\text { concentration } \\
\text { (mg/L) }\end{array}$ & $\begin{array}{c}\text { Catalyst } \\
\text { concentration }\end{array}$ & $\begin{array}{l}\text { Light } \\
\text { source }\end{array}$ & pH & $\begin{array}{c}\text { Removal } \\
\% \text { by } \\
\mathrm{TiO}_{2} \text {-Based } \\
\text { composite } \\
\text { catalysts }\end{array}$ & $\begin{array}{c}\text { Removal } \\
\% \text { by } \\
\text { unmodified } \\
\text { TiO2 }\end{array}$ & $\begin{array}{l}\text { Year } \\
\text { and ref }\end{array}$ \\
\hline 25 & $\begin{array}{l}\text { Pine cone-derived C-doped } \\
\mathrm{TiO}_{2}\end{array}$ & $5(\mathrm{TCH})$ & $0.3 \mathrm{~g} / \mathrm{L}$ & $\begin{array}{l}25 \text { W white vis- } \\
\text { LED strip }^{a}\end{array}$ & 7 & $\begin{array}{l}83 \% \text { after } \\
120 \mathrm{~min}\end{array}$ & - & $\begin{array}{l}2018 \text { Oseghe and } \\
\text { Ofomaja, (2018a) }\end{array}$ \\
\hline 26 & Bismuth-titanate nanoparticles & 50 (TC) & $1 \mathrm{~g} / \mathrm{L}$ & $\begin{array}{l}360 \mathrm{~W} \text { halogen } \\
\text { lamp }(\lambda>400 \mathrm{~nm})\end{array}$ & 7 & $\begin{array}{l}65 \% \text { after } \\
180 \mathrm{~min}\end{array}$ & - & $\begin{array}{l}2017 \text { Khodadoost et al. } \\
\text { (2017) }\end{array}$ \\
\hline 27 & $\mathrm{C}-\mathrm{TiO}_{2}$ nanocomposites & 10 (TC) & $0.2 \mathrm{~g} / \mathrm{L}$ & $--^{\star}$ & 7 & $\begin{array}{c}90 \% \text { after } \\
160 \mathrm{~min}\end{array}$ & $\begin{array}{l}30 \% \text { after } \\
160 \mathrm{~min}\end{array}$ & 2019 Ma et al. (2019) \\
\hline 28 & $\begin{array}{l}\mathrm{CdS}-\mathrm{TiO}_{2} \text { heterostructure } \\
\text { composite }\end{array}$ & $50(\mathrm{TCH})$ & $1 \mathrm{~g} / \mathrm{L}$ & $\begin{array}{l}500 \text { W Xe lamp } \\
(\lambda>400 \mathrm{~nm})\end{array}$ & 7 & $\begin{array}{l}87.06 \% \text { after } \\
480 \mathrm{~min}\end{array}$ & $\begin{array}{l}7.68 \% \text { after } \\
480 \mathrm{~min}\end{array}$ & 2018 Li et al. (2018) \\
\hline 29 & $\mathrm{SrTiO}_{3} / \mathrm{Fe}_{2} \mathrm{O}_{3}$ nanowires & $10(\mathrm{TC})$ & $1 \mathrm{~g} / \mathrm{L}$ & $\begin{array}{l}250 \text { W Xe lamp } \\
(\lambda>420 \mathrm{~nm})\end{array}$ & Free & $\begin{array}{c}82 \% \text { after } \\
140 \mathrm{~min}\end{array}$ & - & 2016 Liu et al. (2016) \\
\hline 30 & $\mathrm{Bi}_{4} \mathrm{Ti}_{3} \mathrm{O}_{12} / \mathrm{BiOCl}$ composite & $20(\mathrm{TCH})$ & $0.66 \mathrm{~g} / \mathrm{L}$ & 300W Xe lamp* & Free & $\begin{array}{l}83.7 \% \text { after } \\
150 \mathrm{~min}\end{array}$ & - & 2018 Liu et al. (2018) \\
\hline 31 & $\begin{array}{l}\text { Perovskite-type W-doped } \\
\mathrm{BaTiO}_{3}\end{array}$ & 5 (TC) & $0.8 \mathrm{~g} / \mathrm{L}$ & $\begin{array}{l}\text { Visible metal } \\
\text { halide light* }\end{array}$ & 5.6 & $\begin{array}{c}93 \% \text { after } \\
180 \text { min }\end{array}$ & - & $\begin{array}{l}2019 \text { Demircivi and } \\
\text { Simsek, (2019) }\end{array}$ \\
\hline 32 & $\begin{array}{l}\text { Platinum-doped amorphous } \\
\mathrm{TiO}_{2} \text {-filled mesoporous } \mathrm{TiO} 2\end{array}$ & $50(\mathrm{TCH})$ & $0.5 \mathrm{~g} / \mathrm{L}$ & 500 W Xe lamp * & 7 & $\begin{array}{l}100 \% \text { after } \\
300 \text { min }\end{array}$ & - & 2019 Lyu et al. (2019) \\
\hline 33 & Mn-doped $\mathrm{SrTiO}_{3}$ nanocubes & 10 (TC) & $1 \mathrm{~g} / \mathrm{L}$ & $\begin{array}{l}250 \mathrm{~W} \text { Xe lamp } \\
(\lambda>420 \mathrm{~nm})\end{array}$ & 7 & $\begin{array}{l}66.7 \% \text { after } \\
60 \mathrm{~min}\end{array}$ & - & 2015 Wu et al. (2015) \\
\hline 34 & $\begin{array}{l}\text { Cu-doped } \mathrm{TiO}_{2} \text { micro/ } \\
\text { nanostructures }\end{array}$ & $20(\mathrm{TCH})$ & 20 mg/L & $\begin{array}{l}1000 \mathrm{~W} \text { Xe }(\lambda> \\
420 \mathrm{~nm})\end{array}$ & 7 & $\begin{array}{l}90 \% \text { after } \\
240 \text { min by } \\
\text { calcined } \mathrm{Cu}- \\
\text { doped } \mathrm{TiO} 2\end{array}$ & $\begin{array}{l}50 \% \text { after } \\
240 \text { min }\end{array}$ & 2018 Cao et al. (2018) \\
\hline 35 & $\begin{array}{l}\text { Carbon-doped } \mathrm{TiO}_{2} \text { ultrathin } \\
\text { nanosheets }\end{array}$ & 20 (TC) & $0.5 \mathrm{~g} / \mathrm{L}$ & $\begin{array}{l}300 \text { W Xe lamp } \\
(\lambda>420 \mathrm{~nm})\end{array}$ & Free & $\begin{array}{l}89.1 \% \text { after } \\
120 \mathrm{~min}\end{array}$ & $\begin{array}{l}50 \% \text { after } \\
120 \text { min }\end{array}$ & 2021 Bao et al. (2021) \\
\hline 36 & $\begin{array}{l}\text { rGO coordinated titania } \\
\text { nanoplatelet }\end{array}$ & $20(\mathrm{TCH})$ & 10 mg/L & $\begin{array}{l}500 \text { W Xe lamp } \\
(350<\lambda> \\
1,100 \mathrm{~nm})\end{array}$ & 7 & $\begin{array}{l}95 \% \text { after } \\
120 \mathrm{~min}\end{array}$ & $\begin{array}{l}70 \% \text { after } \\
120 \text { min }\end{array}$ & 2020 Li C. et al. (2020) \\
\hline
\end{tabular}

a Light wavelength was not specified in the original paper.

Free $\mathrm{pH}$ : medium $\mathrm{pH}$ was not controlled.

Abbreviations: TC, tetracycline; $\mathrm{TCH}$, tetracycline hydrochloride.

\subsection{Titania-Based Composites 5.2.1 Immobilized Titania Composites}

In addition to enhanced visible light activity, the practical and large scale application of Titania would necessitate catalyst stability and recyclability. Accordingly, many studies have investigated the immobilization of doped- $\mathrm{TiO}_{2}$ on various polymeric (Chen Y. et al., 2019; Mahdavi et al., 2019), carbonaceous and ceramic supports such as polyphenylenediamine (POPD) (Yu et al., 2014), graphene, reduced graphene oxide (rGO) (Cao et al., 2016; Huo et al., 2016; Wang W. et al., 2017; Zhang F. J. et al., 2017; Tang et al., 2018; Jamali Alyani et al., 2019; Tabatabai-Yazdi et al., 2020), mesoporous carbon (Fang et al., 2019), MOFs (He et al., 2018; Yuan et al., 2021), zeolites (Saadati et al., 2016b; Liu M. et al., 2019), and silica (Yu et al., 2014; Chen and Liu, 2016; Chen and Liu, 2017; Zyoud et al., 2017; Li J. et al., 2019; Chen Y. et al., 2019; Wang et al., 2019). These systems are prepared as composites (Li R. et al., 2020), and the solid support provides three primary advantages: 1) high surface area which increases tetracycline adsorption, 2) enhanced light absorption and electron entrapment which enhances photocatalytic activity, and 3) reduced sintering and aggregation which leads to superior stability. The superior performance of these composite systems is also attributed to the presence of synergistic effects between the dopant and support (Bahadar Khan and Kalsoom, 2019). Table 6 presents examples of immobilized $\mathrm{TiO}_{2}$-based composite systems and their efficiencies for tetracycline degradation under visible light spectra.

Graphene is a planar form of carbon atoms with a crystal-like honeycomb structure, high specific surface area, good charge carrier transfer, zero band gap energy, and high interfacial adsorbing properties. Graphene immobilization of $\mathrm{TiO}_{2}$ can shift the light spectrum absorbance of the photocatalyst toward visible light and minimize recombination of the electron/hole pairs (Koe et al., 2019). Zhang et al. (Zhang S. et al., 2017) prepared a 2D sandwich-like $\mathrm{TiO}_{2}$-reduced graphene oxide $\left(\mathrm{TiO}_{2}-\mathrm{rGO}\right)$ composite using the Pickering emulsion approach to investigate tetracycline hydrochloride degradation under xenon lamp as a visible light source. The unique mesoporous structure on both sides of the rGO significantly enhanced the tetracycline hydrochloride degradation by increasing the surface area of the catalyst and adsorption of the contaminant, promoting electron transfer, and minimizing recombination of the $\left(e^{-}\right) /\left(h^{+}\right)$pairs. $\mathrm{TiO}_{2}-\mathrm{rGO}$ degraded $(96 \%)$ of the initial tetracycline hydrochloride concentration, whereas unmodified $\mathrm{TiO}_{2}$ only degraded $(28 \%)$ of the tetracycline hydrochloride. The authors suggested that the large number of mesoporous voids increased the number of exposed active sites of 
$\mathrm{TiO}_{2}$, decreased the transport route length, and accelerated the electron transfer step. The visible light activity of this grapheneimmobilized catalyst was attributed to the addition of rGO, which lowered the band gap energy of $\mathrm{TiO}_{2}$ to 3.05 .

Polymeric supports are nontoxic, low cost, widely available, resistant to UV light, durable, mechanically stable, and photostable. The hydrophobic properties of many polymers enables them to promote catalyst adsorption by increasing the pollutant concentration on its outer surface (Arif et al., 2020). Wang et al. (Wang C. et al., 2017) prepared a photocatalytic nanocomposite membrane of Au-doped $\mathrm{TiO}_{2}$ supported on polydopamine (pDA)-coated polyvinylidene fluoride (PVDF) $\left(\mathrm{Au}-\mathrm{TiO}_{2} / \mathrm{pDA} /\right.$ PVDF). The nanocomposite membrane was used to degrade tetracycline under $300 \mathrm{~W}$ Xenon lamp as a visible light source. The authors reported that the visible light-induced tetracycline removal efficiency of $\mathrm{Au}-\mathrm{TiO}_{2} / \mathrm{pDA} / \mathrm{PVDF}$ was (51\%) higher than that of undoped $\mathrm{TiO}_{2} / \mathrm{pDA} / \mathrm{PVDF}$ and $(26 \%)$ higher than that of Au-doped $\mathrm{TiO}_{2}$. They also reported that $\mathrm{pDA}$ acted as a glue to stabilize $\mathrm{TiO}_{2}$ on the PVDF membrane, and functioned as a photosensitizer to widen the light absorbance spectrum of the catalyst. The authors proposed that the plasmon resonance effect of Au enhanced catalyst activity by accelerating photogenerated electron transfer from $\mathrm{Au}$ into the conduction band of the mother catalyst $\mathrm{TiO}_{2}$.

Ceramics have a large surface area, very good permeability, excellent strength, and high absorptivity (Mohd Adnan et al., 2018). Chen et al. (Chen and Liu, 2017) used the sol-gel method to prepare a magnetically recyclable $\mathrm{Ce} / \mathrm{N}$ co-doped $\mathrm{TiO}_{2} / \mathrm{NiFe}_{2} \mathrm{O}_{4} /$ diatomite ternary hybrid catalyst (CN-TND) for tetracycline degradation under $150 \mathrm{~W}$ xenon lamp as a visible light source. Each of the $\mathrm{N}$ and Ce dopants improved the photocatalyst surface properties and suppressed the formation of $\mathrm{TiO}_{2}$ crystals. The authors observed that $\mathrm{Ce} / \mathrm{N}$ co-doped $\mathrm{TiO}_{2} /$ diatomite exhibited a slight redshift in its light absorption spectrum. CNTND had slightly better tetracycline degradation efficiency (98\%) than the $\mathrm{N}$-doped $\mathrm{TiO}_{2} / \mathrm{NiFe}_{2} \mathrm{O}_{4} /$ diatomite (95\%) degradation efficiency due to the addition of $\mathrm{Ce}$. The presence of ferrite $\left(\mathrm{NiFe}_{2} \mathrm{O}_{4}\right)$ enhanced electron transfer and reduced charge carrier recombination. The improved performance of CN-TND was ascribed to the synergistic effect of the $\mathrm{Ce}$ and $\mathrm{N}$ dopants, which effectively widened the visible light absorption by the catalyst. CN-TND had ferromagnetism properties, was easily recovered from the reaction medium, and was reused five times with minimal loss in activity (0.5\%). CN-TND achieved nearly complete tetracycline mineralization with (100\%) TOC removal compared to only (52\%) removal by the $\mathrm{Ce} / \mathrm{N}$ co-doped $\mathrm{TiO}_{2}$.

Microporous structured supports such as zeolites were investigated for $\mathrm{TiO}_{2}$ modification. Liu et al. (Liu M. et al., 2019) used the hydrothermal method to synthesize a $\mathrm{Fe}_{2} \mathrm{O}_{3^{-}}$$\mathrm{TiO}_{2} / \mathrm{Fe}$-Zeolite immobilized composite $\left(\mathrm{Fe}_{2} \mathrm{O}_{3}-\mathrm{TiO}_{2} / \mathrm{FeZ}\right)$. The composite catalyst was tested for oxytetracycline degradation using a $200 \mathrm{~W} 455 \mathrm{~nm}$ LED lamp as a visible light source. The $\mathrm{Fe}_{2} \mathrm{O}_{3}-\mathrm{TiO}_{2} / \mathrm{FeZ}$ composite exhibited a higher surface area $\left(1,445 \mathrm{~m}^{2} / \mathrm{g}\right)$ than that of zeolite $\left(844 \mathrm{~m}^{2} / \mathrm{g}\right)$, and had outstanding adsorption of oxytetracycline (94\%) and improved activity under visible light. The visible light photocatalytic degradation efficiency of $\mathrm{Fe}_{2} \mathrm{O}_{3}-\mathrm{TiO}_{2} / \mathrm{FeZ}$ was (98\%), indicating its improved visible light absorption (400-600 nm), high adsorption of oxytetracycline, and enhanced rate of photogenerated charge carriers. $\mathrm{Fe}_{2} \mathrm{O}_{3}-\mathrm{TiO}_{2} / \mathrm{FeZ}$ had good stability after the fourth use and maintained $(80 \%)$ efficiency.

In addition to zeolites, metal-organic frameworks (MOFs) have been investigated for the immobilization of $\mathrm{TiO}_{2}$. MOFs are hybrid organic-inorganic, low cost, and environmentally friendly micro-porous materials with unique morphological properties and superior surface areas (Gautam et al., 2020). When combined with semiconductors such as $\mathrm{TiO}_{2}, \mathrm{MOFs}$ form hierarchical nanostructures with enhanced photocatalytic properties (He et al., 2018). He et al. (He et al., 2018) applied onedimensional MOF [Materials Institute Lavoisier 1D (MIL)$100(\mathrm{Fe})]$ over $\mathrm{TiO}_{2}$ nanoarrays [1D MIL-100(Fe)/TiO ${ }_{2}$ ] by insitu growth of MIL-100(Fe) on the $\mathrm{TiO}_{2}$ nanoarrays. The catalyst was tested for tetracycline degradation using a $450 \mathrm{~W}$ $\mathrm{Xe} \mathrm{lamp} \mathrm{as} \mathrm{a} \mathrm{visible} \mathrm{light} \mathrm{source} \mathrm{(He} \mathrm{et} \mathrm{al.,} \mathrm{2018).} \mathrm{The} \mathrm{growth} \mathrm{of}$ 1D MIL-100(Fe) over $\mathrm{TiO}_{2}$ nanoarrays increased the surface roughness of these nanoarrays, enhanced the visible light absorption of the composite catalyst $(<600 \mathrm{~nm})$, and improved the electron/hole separation and the accessibility of active sites. The composite $1 \mathrm{D}$ MIL-100 $(\mathrm{Fe}) / \mathrm{TiO}_{2}$ photocatalyst achieved (90.79\%) tetracycline degradation efficiency compared to only (35.22\%) degradation efficiency achieved by unmodified $\mathrm{TiO}_{2}$ nanoarrays. The composite catalyst was easily recovered and maintained good stability (70\%) after the fifth use.

The proposed mechanism of tetracycline degradation by $1 \mathrm{D}$ MIL- $100(\mathrm{Fe}) / \mathrm{TiO}_{2}$ is presented in Figure 4. Upon irradiation, electrons in the $\mathrm{VB}$ of $\mathrm{TiO}_{2}$ are excited into its $\mathrm{CB}$ (Eq. 1), while MIL- $100(\mathrm{Fe})$ is activated $v i a$ the direct excitation of $\mathrm{FeO}$ as well as ligand-to-metal charge transfer. The electrons and holes react with water and oxygen molecules to produce $(\bullet \mathrm{OH})$ and $\left(\mathrm{O}_{2}^{\bullet-}\right)$ radicals (Eqs 2, 3, 7, 8, 9, 10). In the presence of $\mathrm{H}_{2} \mathrm{O}_{2}, \mathrm{Fe}(\mathrm{III})$ in MIL-100(Fe) undergoes Fenton-like reactions and reacts with $\mathrm{H}_{2} \mathrm{O}_{2}$ to further boost the formation of $(\bullet \mathrm{OH})$ radicals as shown in (Figure 4). The formed radicals synergistically degrade TC molecules under visible light (Eqs 4, 5, 6).

\subsubsection{Nanostructured Titania Composites}

Nanostructured Titania composites enhance the catalyst's surface area and crystal morphology, and they include $\mathrm{TiO}_{2}$-based nanospheres, nanosheets, nanowires, nanorods, nanotubes, and nanoparticles (Choi et al., 2014; Bahadar Khan and Kalsoom, 2019). Nanostructured Titania composites also enhance chemical, mechanical, electronic, and optical properties of Titania. Table 6 presents examples of nanostructured $\mathrm{TiO}_{2}{ }^{-}$ based composite systems that have been used for tetracyclines degradation under visible light.

Chen et al. (Chen et al., 2016) used the electrochemical anodic oxidation method to modify immobilized $\mathrm{TiO}_{2}$ nanobelts (NBs) with $\mathrm{Au}$ and $\mathrm{CuS}$ nanoparticles, and tested the composite catalyst for oxytetracycline removal using simulated solar light irradiation ( $35 \mathrm{~W}$ Xe lamp). Au-CuS/TiO ${ }_{2} \mathrm{NBs}$ exhibited enhanced visible light (solar) absorption due the lowest band gap energy $(2.65 \mathrm{eV})$ and the highest visible light absorption intensity $(520-620 \mathrm{~nm})$ compared to $\mathrm{Au}-\mathrm{TiO}_{2} \mathrm{NBs}$, CuS-TiO${ }_{2} \mathrm{NBs}$, and $\mathrm{TiO}_{2} \mathrm{NBs}$. The oxytetracycline degradation efficiency of $\mathrm{Au}-\mathrm{CuS} / \mathrm{TiO}_{2} \mathrm{NBs}$ after 


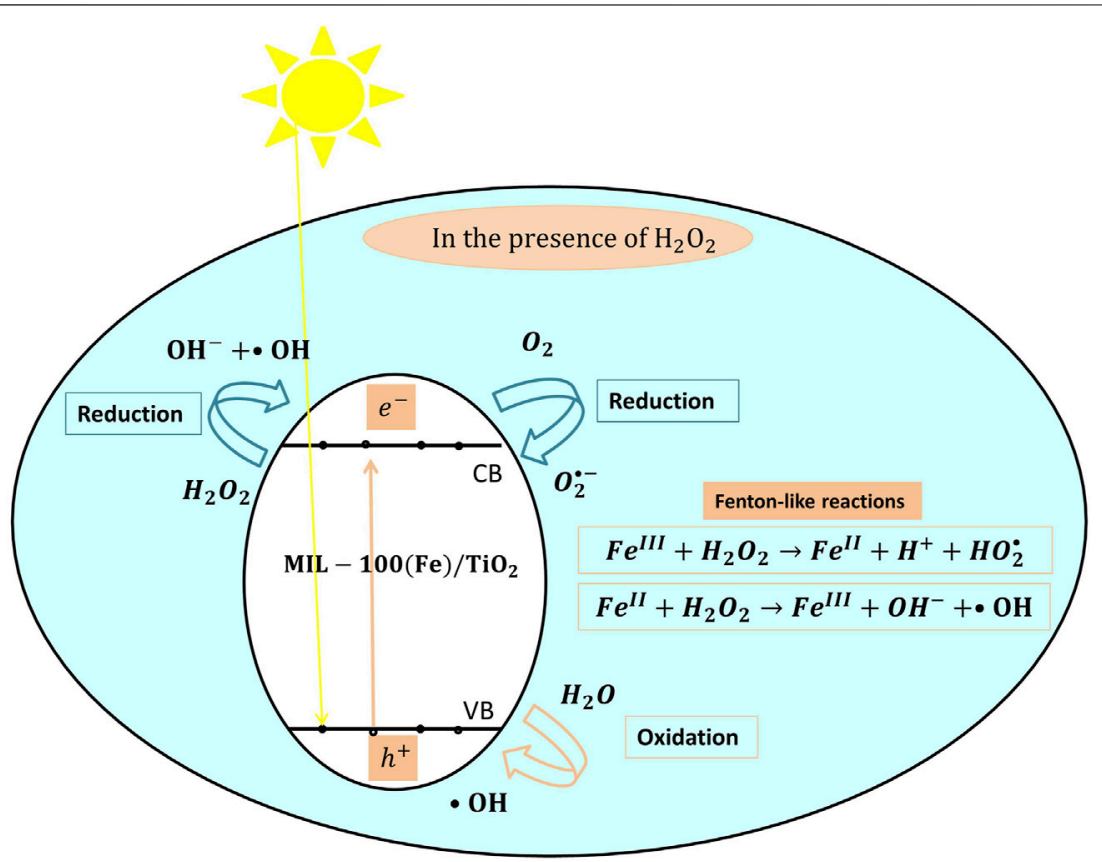

FIGURE 4 | The proposed photocatalytic degradation mechanism of tetracycline by 1D MIL-100(Fe)/TiO ${ }_{2}$ catalyst under visible light.

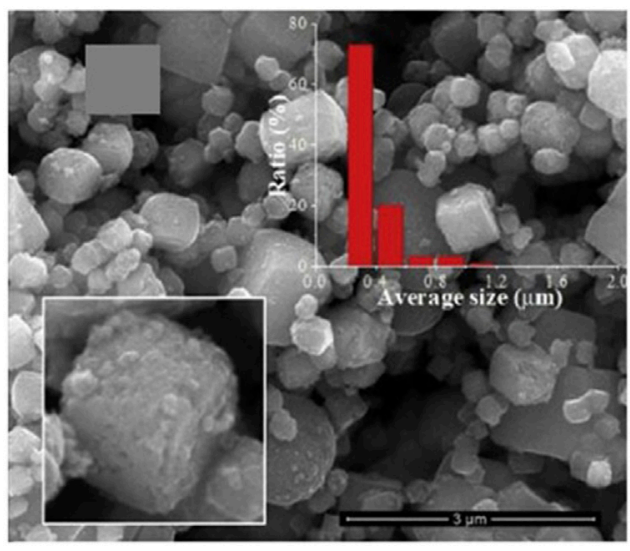

FIGURE 5 | SEM image of the core-shell structured platinum (Pt)enhanced amorphous (Am) $\mathrm{TiO}_{2}$-filled mesoporous $\mathrm{TiO}_{2}$ crystals (MCs) (MCs@Pt@Am) photocatalyst, reprinted with permission from Elsevier (Lyu et al., 2019).

$1 \mathrm{~h}$ was as high as (96\%), whereas the oxytetracycline degradation efficiencies of $\mathrm{Au}-\mathrm{TiO}_{2} \mathrm{NBs}, \mathrm{CuS}-\mathrm{TiO}_{2} \mathrm{NBs}$, and $\mathrm{TiO}_{2} \mathrm{NBs}$ were $(85 \%),(76 \%)$, and $(66 \%)$, respectively. The authors ascribed the improved degradation efficiency of this catalyst to its ability to hinder recombination of photogenerated electron-hole pairs as a result of efficient interfacial charge transfer, and to the increased number of charge carriers participating in photocatalysis. The authors also concluded that visible light absorption was promoted by the plasmon resonance effect of $\mathrm{Au}$, whereas $\mathrm{CuS}-\mathrm{TiO}_{2} \mathrm{NBs}$ promoted light absorption in the near-infrared region. Additionally, the authors attributed the improved performance of $\mathrm{Au}-\mathrm{CuS} / \mathrm{TiO}_{2}$ to the ideal dispersion of both the $\mathrm{Au}$ and $\mathrm{CuS}$ on the smooth surface of $\mathrm{TiO}_{2} \mathrm{NBs}$ that formed a uniform surface composite structure. The total organic carbon (TOC) removal efficiency achieved by $\mathrm{Au}-\mathrm{CuS} / \mathrm{TiO}_{2} \mathrm{NBs}$ was $(68 \%)$, whereas that of $\mathrm{TiO}_{2}$ NBs was only (40\%).

Lyu et al. (Lyu et al., 2019) used the hydrothermal method coupled with chemical reduction to prepare platinum $(\mathrm{Pt})$ enhanced amorphous (Am) $\mathrm{TiO}_{2}$-filled mesoporous $\mathrm{TiO}_{2}$ crystals (MCs) (MCs@Pt@Am). This catalyst was tested for tetracycline hydrochloride degradation using a $500 \mathrm{~W}$ xenon lamp as a visible light source (Lyu et al., 2019). The authors created a new hierarchical porous core-shell structure by filling amorphous $\mathrm{TiO}_{2}$ in the pores of $\mathrm{Pt}$-doped mesoporous $\mathrm{TiO}_{2}$ crystals, and reported that the core-shell structured catalyst (Figure 5) exhibited a larger surface area and particle size, higher tetracycline hydrochloride adsorption capacity, and reduced shell thickness as compared to $\mathrm{TiO}_{2}$ crystals. These properties inhibited recombination of the electron/hole pairs and facilitated the migration of the positive hole into the catalyst surface while Pt-doping reduced the band gap energy of the catalyst and enhanced its visible light absorption. The photocatalytic degradation efficiency of tetracycline hydrochloride by MCs@Pt@Am was (100\%), whereas that of amorphous $\mathrm{TiO}_{2}$-coated mesoporous $\mathrm{TiO}_{2}$ crystals was (89\%), and that of mesoporous $\mathrm{TiO}_{2}$ crystals was (60\%). MCs@Pt@Am degraded (77\%) of the initial TOC content, whereas amorphous $\mathrm{TiO}_{2}$-coated mesoporous $\mathrm{TiO}_{2}$ crystals degraded only $(60 \%)$ of the initial TOC concentration. 
TABLE 7 | Examples of titania-based heterojunction photocatalysts.

\begin{tabular}{|c|c|c|c|c|c|c|c|c|}
\hline \# & $\begin{array}{l}\text { Modified } \\
\text { titania }\end{array}$ & $\begin{array}{c}\text { TCs initial } \\
\text { concentration } \\
\text { (mg/L) }\end{array}$ & $\begin{array}{c}\text { Catalyst } \\
\text { concentration }\end{array}$ & $\begin{array}{l}\text { Light } \\
\text { source }\end{array}$ & $\mathrm{pH}$ & $\begin{array}{c}\text { Removal } \\
\% \text { by } \\
\mathrm{TiO}_{2} \text {-Based } \\
\text { heterojunction } \\
\text { photocatalysts }\end{array}$ & $\begin{array}{c}\text { Removal } \\
\% \text { by } \\
\text { titania }\end{array}$ & $\begin{array}{l}\text { Year } \\
\text { and ref }\end{array}$ \\
\hline \multicolumn{9}{|c|}{ A. Titania-Based heterojunctions: Binary heterojunctions } \\
\hline 1 & $\begin{array}{l}\mathrm{TiO}_{2} @ \text { sulfur- doped } \\
\text { carbon nitride } \\
\text { nanocomposite }\end{array}$ & $10(\mathrm{TC})$ & $0.1 \mathrm{~g} / \mathrm{L}$ & $\begin{array}{l}300 \text { W xenon }(\mathrm{xe}) \\
\text { lamp }(\lambda> \\
420 \mathrm{~nm})\end{array}$ & 4.5 & $\begin{array}{l}98.1 \% \text { after } \\
60 \mathrm{~min}\end{array}$ & $\begin{array}{l}35.1 \% \text { after } \\
60 \mathrm{~min}\end{array}$ & $\begin{array}{l}2021 \text { Divakaran et al. } \\
\text { (2021) }\end{array}$ \\
\hline 2 & $\begin{array}{l}\mathrm{N} \text {-doped } \mathrm{TiO}_{2} @ \\
\mathrm{Bi}_{2} \mathrm{~W}_{x} \mathrm{Mo}_{1}-\mathrm{O}_{6} \text { core-shell } \\
\text { nanofibers }\end{array}$ & $40(\mathrm{TC})$ & $0.3 \mathrm{~g} / \mathrm{L}$ & $\begin{array}{l}300 \text { W Xe lamp }(\lambda \\
>400 \mathrm{~nm})\end{array}$ & 6 & $\begin{array}{l}100 \% \text { after } \\
90 \text { min }\end{array}$ & $\begin{array}{l}20 \% \text { after } \\
90 \text { min }\end{array}$ & $\begin{array}{l}2020 \text { Ghoreishian } \\
\text { et al. (2020) }\end{array}$ \\
\hline 3 & $\begin{array}{l}\mathrm{TiO}_{2} \text { nanoparticle/ } \\
\mathrm{SnNb}_{2} \mathrm{O}_{6} \text { nanosheet }\end{array}$ & $35(\mathrm{TCH})$ & $1 \mathrm{~g} / \mathrm{L}$ & $\begin{array}{l}500 \text { W Tungsten } \\
\text { lampa }^{a}\end{array}$ & Free & $\begin{array}{l}75.5 \% \text { after } \\
240 \mathrm{~min}\end{array}$ & $\begin{array}{l}63.8 \% \text { after } \\
240 \mathrm{~min}\end{array}$ & 2017 Jin et al. (2017) \\
\hline 4 & $\mathrm{CuO} / \mathrm{Ti}-\mathrm{MCM}-48$ & $19.24(\mathrm{TCH})$ & $1 \mathrm{~g} / \mathrm{L}$ & Solar simulator ${ }^{\mathrm{a}}$ & Free & $93 \%$ after $80 \mathrm{~min}$ & $\begin{array}{l}50 \% \text { after } \\
80 \text { min }\end{array}$ & $\begin{array}{l}2018 \text { Duan et al. } \\
\text { (2018) }\end{array}$ \\
\hline 5 & $\begin{array}{l}\mathrm{TiO}_{2} \text {-coated } \alpha-\mathrm{Fe}_{2} \mathrm{O}_{3} \\
\text { core-shell heterojunction }\end{array}$ & $50(\mathrm{TCH})$ & $0.2 \mathrm{~g} / \mathrm{L}$ & $\begin{array}{l}300 \text { W Xe lamp }(\lambda \\
>420 \mathrm{~nm})\end{array}$ & 5.5 & $\begin{array}{c}100 \% \text { after } \\
120 \text { min }\end{array}$ & - & $\begin{array}{l}2018 \text { Zheng et al. } \\
\text { (2018) }\end{array}$ \\
\hline 6 & $\begin{array}{l}\mathrm{CeO}_{x} \text {-coupled } \mathrm{MIL}-125 \text { - } \\
\text { derived } \mathrm{C}-\mathrm{TiO}_{2}\end{array}$ & $40(\mathrm{TC})$ & $1 \mathrm{~g} / \mathrm{L}$ & $\begin{array}{l}500 \text { W Xe lamp }(\lambda \\
>400 \mathrm{~nm})\end{array}$ & Free & $\begin{array}{l}83.5 \% \text { after } \\
180 \mathrm{~min}\end{array}$ & $\begin{array}{l}30.3 \% \text { after } \\
180 \mathrm{~min}\end{array}$ & $\begin{array}{l}2021 \text { Yuan et al. } \\
(2021)\end{array}$ \\
\hline 7 & $\begin{array}{l}\text { Ultrafine } \mathrm{TiO}_{2} \\
\text { nanoparticle-modified } \\
\mathrm{g}-\mathrm{C}_{3} \mathrm{~N}_{4} \text { heterojunction }\end{array}$ & $20(\mathrm{TCH})$ & $0.25 \mathrm{~g} / \mathrm{L}$ & 150 W Xe lampa & 7 & $\begin{array}{l}99.4 \% \text { after } \\
120 \mathrm{~min}\end{array}$ & $\begin{array}{l}95.81 \% \text { after } \\
120 \mathrm{~min}\end{array}$ & $\begin{array}{l}2020 \text { Zhang B. et al. } \\
\text { (2020) }\end{array}$ \\
\hline 8 & $\begin{array}{l}\text { Black- } \mathrm{TiO}_{2} / \mathrm{CoTiO}_{3} \\
\text { Z-scheme heterojunction }\end{array}$ & 20 (TC) & $1 \mathrm{~g} / \mathrm{L}$ & $\begin{array}{l}50 \mathrm{~W} \text { LED lamps } \\
(450<\lambda< \\
650 \mathrm{~nm})\end{array}$ & Free & $\begin{array}{l}82.4 \% \text { after } \\
30 \mathrm{~min}\end{array}$ & $\begin{array}{l}28.3 \% \text { after } \\
80 \text { min by } \\
\text { black- } \mathrm{TiO}_{2}\end{array}$ & $\begin{array}{l}2021 \text { Mousavi and } \\
\text { Ghasemi, (2021) }\end{array}$ \\
\hline 9 & $\begin{array}{l}\mathrm{TiO}_{2} / \text { high-crystalline } \\
\mathrm{g}-\mathrm{C}_{3} \mathrm{~N}_{4} \text { composite }\end{array}$ & $10(\mathrm{TC})$ & $0.2 \mathrm{~g} / \mathrm{L}$ & $\begin{array}{l}300 \text { W Xe lamp }(\lambda \\
>400 \mathrm{~nm})\end{array}$ & Free & $\begin{array}{c}91 \% \text { after } \\
120 \text { min }\end{array}$ & $\begin{array}{l}6 \% \text { after } \\
120 \mathrm{~min}\end{array}$ & 2020 Guo et al. (2020) \\
\hline 10 & $\begin{array}{l}\mathrm{Ag} / \mathrm{Ag}_{3} \mathrm{PO}_{4} \text { nanoparticles/ } \\
\text { cobalt- doped } \mathrm{TiO}_{2} \\
\text { nanosheets }\end{array}$ & $20(\mathrm{TC})$ & $1 \mathrm{~g} / \mathrm{L}$ & $\begin{array}{l}500 \text { W halogen } \\
\text { lampa }^{a}\end{array}$ & Free & $\begin{array}{l}66.80 \% \text { after } \\
140 \mathrm{~min}\end{array}$ & - & $\begin{array}{l}2021 \text { Mokhtari Nesfchi } \\
\text { et al. (2021) }\end{array}$ \\
\hline 11 & $\begin{array}{l}\mathrm{TiO}_{2} \text {-coupled } \mathrm{NiTiO}_{3} \\
\text { nanocomposites }\end{array}$ & - & $1 \mathrm{~g} / \mathrm{L}$ & $\begin{array}{l}250 \text { W Xe lamp } \\
(\text { UV-vis, } 300<\lambda< \\
800 \mathrm{~nm})\end{array}$ & Free & $\begin{array}{l}58 \% \text { after } \\
120 \mathrm{~min}\end{array}$ & - & $\begin{array}{l}2018 \text { Lakhera et al. } \\
\text { (2018) }\end{array}$ \\
\hline 12 & $\mathrm{BiOXs} / \mathrm{TiO}_{2}$ & 30 (TC) & $0.2 \mathrm{~g} / \mathrm{L}$ & $\begin{array}{l}300 \text { W Xe lamp }(\lambda \\
>400 \mathrm{~nm})\end{array}$ & Free & $\begin{array}{c}90 \% \text { after } \\
180 \text { min }\end{array}$ & $\begin{array}{c}80 \% \text { after } \\
180 \text { min }\end{array}$ & 2019 Li L. et al. (2019) \\
\hline 13 & $\begin{array}{l}\mathrm{BiFeO}_{3} / \mathrm{TiO}_{2} \mathrm{p}-\mathrm{n} \\
\text { heterojunction }\end{array}$ & 20 (TC) & $1 \mathrm{~g} / \mathrm{L}$ & 300 W Xe lampa & 5 & $\begin{array}{c}72.2 \% \text { after } \\
180 \mathrm{~min}\end{array}$ & $\begin{array}{l}38.3 \% \text { after } \\
180 \mathrm{~min}\end{array}$ & 2021 Liao et al. (2021) \\
\hline 14 & $\mathrm{Co}_{3} \mathrm{O}_{4}-\mathrm{TiO}_{2} / \mathrm{GO}$ & 10 Oxy-(TC) & $0.25 \mathrm{~g} / \mathrm{L}$ & $\begin{array}{l}300 \mathrm{~W} \text { Xe solar } \\
\text { simulator }(\lambda> \\
420 \mathrm{~nm})\end{array}$ & Free & $91 \%$ after $90 \mathrm{~min}$ & $\begin{array}{l}30 \% \text { after } \\
90 \text { min }\end{array}$ & 2017 Jo et al. (2017) \\
\hline 15 & $\begin{array}{l}\text { Reduced graphene oxide- } \\
\mathrm{Ag}_{2} \mathrm{O} / \mathrm{TiO}_{2} \text { nanobelts } \\
\text { composites }\end{array}$ & $10(\mathrm{TC})$ & $0.4 \mathrm{~g} / \mathrm{L}$ & $\begin{array}{l}300 \mathrm{~W} \text { Xe arc } \\
\text { lamp }(\lambda> \\
420 \mathrm{~nm})\end{array}$ & Free & $18 \%$ after $60 \mathrm{~min}$ & $\begin{array}{l}18 \% \text { after } \\
60 \text { min }\end{array}$ & 2017 Hu et al. (2017) \\
\hline 16 & $\begin{array}{l}\text { Z-scheme } \mathrm{CdTe} / \mathrm{TiO}_{2} \\
\text { heterostructure }\end{array}$ & $20(\mathrm{TCH})$ & $0.6 \mathrm{~g} / \mathrm{L}$ & $\begin{array}{l}400 \mathrm{~W} \text { halogen } \\
\text { lamp }(\lambda> \\
420 \mathrm{~nm})\end{array}$ & Free & $78 \%$ after $30 \mathrm{~min}$ & $\begin{array}{l}62 \% \text { after } \\
30 \mathrm{~min}\end{array}$ & $\begin{array}{l}2018 \text { Gong et al. } \\
(2018)\end{array}$ \\
\hline 17 & $\begin{array}{l}\text { Carbon fiber/ } / \mathrm{TiO}_{2} / \mathrm{Bi}_{2} \mathrm{WO}_{6} \\
\text { heterojunctions }\end{array}$ & $10(\mathrm{TCH})$ & $\begin{array}{l}\text { Bundles (length } \sim 4 \mathrm{~cm} \text {, } \\
\text { weight } 0.15 \mathrm{~g} \text { ) }\end{array}$ & $\begin{array}{l}300 \text { W Xe lamp }(\lambda \\
>400 \mathrm{~nm})\end{array}$ & Free & $\begin{array}{l}95.1 \% \text { after } \\
60 \mathrm{~min}\end{array}$ & - & 2018 Xu et al. (2018) \\
\hline 18 & $\mathrm{TiO}_{2} / \mathrm{BiOCl}$ composite & 30 (TC) & $1 \mathrm{~g} / \mathrm{L}$ & $\begin{array}{l}300 \text { W Xe lamp }(\lambda \\
>400 \mathrm{~nm})\end{array}$ & 3 & $\begin{array}{l}90 \% \text { after } \\
240 \text { min }\end{array}$ & $\begin{array}{l}33 \% \text { after } \\
240 \mathrm{~min}\end{array}$ & 2019 Hu et al. (2019) \\
\hline 19 & $\begin{array}{l}\text { Mo-C co-doped } \mathrm{TiO}_{2} \text { with } \\
\text { fluorine-doped tin- oxide }\end{array}$ & $20(\mathrm{TC})$ & - & $\begin{array}{l}500 \text { W Xe lamp }(\lambda \\
>420 \mathrm{~nm})\end{array}$ & 7 & $\begin{array}{c}90 \% \text { after } \\
100 \text { min }\end{array}$ & - & 2019 Niu et al. (2019) \\
\hline 20 & $\begin{array}{l}\mathrm{N} \text {-doped } \mathrm{TiO}_{2} / \text { calcium } \\
\text { ferrite/diatomite }\end{array}$ & 10 (TC) & $1 \mathrm{~g} / \mathrm{L}$ & $\begin{array}{l}150 \text { W Xe lamp }(\lambda \\
>400 \mathrm{~nm})\end{array}$ & Free & $\begin{array}{l}91.7 \% \text { after } \\
120 \mathrm{~min}\end{array}$ & - & $\begin{array}{l}2019 \text { Chen Y. et al. } \\
\text { (2019) }\end{array}$ \\
\hline 21 & $\begin{array}{l}\mathrm{N} \text {-doped } \mathrm{TiO}_{2} / \text { strontium } \\
\text { ferrite/diatomite }\end{array}$ & $10(\mathrm{TC})$ & $2 \mathrm{~g} / \mathrm{L}$ & $\begin{array}{l}150 \text { W Xe lamp }(\lambda \\
>400 \mathrm{~nm})\end{array}$ & Free & $\begin{array}{l}92.2 \% \text { after } \\
120 \mathrm{~min}\end{array}$ & - & 2019 Wu, (2019) \\
\hline 22 & $\begin{array}{l}\mathrm{g}-\mathrm{C}_{3} \mathrm{~N}_{4} @ \mathrm{Co}-\mathrm{TiO}_{2} \\
\text { membrane }\end{array}$ & $20(\mathrm{TCH})$ & $\begin{array}{c}5 \mathrm{mg} \text { of membranes ( } 2 \\
\left.\times 2 \mathrm{~cm}^{2}\right) / 10 \mathrm{ml} \text { of } \\
\text { solution }\end{array}$ & $\begin{array}{l}300 \text { W Xe lamp }(\lambda \\
>420 \mathrm{~nm})\end{array}$ & 7 & $\begin{array}{l}90.8 \% \text { within } \\
60 \mathrm{~min}\end{array}$ & - & $\begin{array}{l}2020 \text { Song et al. } \\
(2020)\end{array}$ \\
\hline 23 & $\mathrm{CeO}_{2} / \mathrm{TiO}_{2}$ composites & $40(\mathrm{TC})$ & $1 \mathrm{~g} / \mathrm{L}$ & $\begin{array}{l}500 \text { W Xe lamp }(\lambda \\
>420 \mathrm{~nm})\end{array}$ & Free & $\begin{array}{l}99 \% \text { within } \\
80 \text { min }\end{array}$ & $\begin{array}{l}10 \% \text { within } \\
80 \text { min }\end{array}$ & $\begin{array}{l}2020 \text { Pudukudy et al. } \\
\text { (2020) }\end{array}$ \\
\hline 24 & $\begin{array}{l}\mathrm{MnCo}_{2} \mathrm{O}_{4.5} \text { Deposited } \\
\mathrm{TiO}_{2} \mathrm{Nanotube} \mathrm{Array}\end{array}$ & $10(\mathrm{TC})$ & $2.25 \mathrm{~cm}^{2}$ & 500 W Xe lampa & Free & $\begin{array}{l}93.1 \% \text { within } \\
120 \mathrm{~min}\end{array}$ & - & 2020 Bi et al. (2020) \\
\hline
\end{tabular}

(Continued on following page) 
TABLE 7 | (Continued) Examples of titania-based heterojunction photocatalysts.

\begin{tabular}{|c|c|c|c|c|c|c|c|c|}
\hline$\#$ & $\begin{array}{l}\text { Modified } \\
\text { titania }\end{array}$ & $\begin{array}{c}\text { TCs initial } \\
\text { concentration } \\
\text { (mg/L) }\end{array}$ & $\begin{array}{c}\text { Catalyst } \\
\text { concentration }\end{array}$ & $\begin{array}{l}\text { Light } \\
\text { source }\end{array}$ & pH & $\begin{array}{c}\text { Removal } \\
\% \text { by } \\
\mathrm{TiO}_{2} \text {-Based } \\
\text { heterojunction } \\
\text { photocatalysts }\end{array}$ & $\begin{array}{c}\text { Removal } \\
\% \text { by } \\
\text { titania }\end{array}$ & $\begin{array}{l}\text { Year } \\
\text { and ref }\end{array}$ \\
\hline \multicolumn{9}{|c|}{ B. Titania-Based Heterojunctions: Ternary Heterojunctions } \\
\hline 25 & $\begin{array}{l}\text { Carbon plane/g- } \mathrm{C}_{3} \mathrm{~N}_{4} / \\
\mathrm{TiO}_{2} \text { nanocomposite }\end{array}$ & $10(\mathrm{TC})$ & $1 \mathrm{~g} / \mathrm{L}$ & $\begin{array}{l}500 \text { W Xe lamp }(\lambda \\
>400 \mathrm{~nm})\end{array}$ & Free & $\begin{array}{l}94.0 \% \text { after } \\
180 \mathrm{~min}\end{array}$ & $\begin{array}{c}46 \% \text { after } \\
180 \text { min }\end{array}$ & $\begin{array}{l}2019 \text { Liu C. et al. } \\
\text { (2019) }\end{array}$ \\
\hline 26 & $\begin{array}{l}\text { K-doped g- } \mathrm{C}_{3} \mathrm{~N}_{4} / \\
\mathrm{TiO}_{2} / \mathrm{CdS}\end{array}$ & $20(\mathrm{TC})$ & $1 \mathrm{~g} / \mathrm{L}$ & $\begin{array}{l}300 \text { W Xe lamp }(\lambda \\
>420 \mathrm{~nm})\end{array}$ & Free & $\begin{array}{l}94.2 \% \text { after } \\
30 \mathrm{~min}\end{array}$ & $\begin{array}{l}69.47 \% \text { after } \\
30 \mathrm{~min}\end{array}$ & 2021 Liu et al. (2021) \\
\hline 27 & $\begin{array}{l}\mathrm{g}-\mathrm{C}_{3} \mathrm{~N}_{4} / \mathrm{Ti}_{3} \mathrm{C}_{2} / \mathrm{TiO}_{2} \\
\text { nanotube arrays on } \mathrm{Ti} \\
\text { meshes }\end{array}$ & $10(\mathrm{TCH})$ & $1.5 \times 1.0 \mathrm{~cm}$ & $\begin{array}{l}300 \text { W Xe lamp }(\lambda \\
>420 \mathrm{~nm})\end{array}$ & Free & $\begin{array}{l}85.12 \% \text { after } \\
180 \mathrm{~min}\end{array}$ & - & 2020 Diao et al. (2020) \\
\hline \multicolumn{9}{|c|}{ C. Titania-Based Homogeneous Junctions: Facet Junction } \\
\hline 28 & $\begin{array}{l}\{101\} \text { and }\{001\} \text { facets co- } \\
\text { exposed } \mathrm{TiO}_{2} \text { hollow } \\
\text { sphere }\end{array}$ & $10(\mathrm{TC})$ & $0.2 \mathrm{~g} / \mathrm{L}$ & $\begin{array}{l}300 \text { W Xe lamp }(\lambda \\
>400 \mathrm{~nm})\end{array}$ & Free & $\begin{array}{l}90.1 \% \text { after } \\
120 \mathrm{~min}\end{array}$ & - & $\begin{array}{l}2020 \text { Zhang S. et al. } \\
(2020)\end{array}$ \\
\hline
\end{tabular}

a Light wavelength was not specified in the original paper.

Free $\mathrm{pH}$ : medium $\mathrm{pH}$ was not controlled.

Abbreviations: TC, tetracycline; $\mathrm{TCH}$, tetracycline hydrochloride.

All reported composite systems significantly improve $\mathrm{TiO}_{2}$ catalyst performance for tetracyclines degradation under visible light. These properties arise from the synergistic effects between different moieties of the composite system and from the enhanced surface area and morphology of the photocatalyst. Many studies have successfully constructed and applied immobilized and nanostructured Titania composites for tetracycline degradation under visible light, and we conclude that both approaches are valuable for Titania modification. Although both immobilized and nanostructured Titania composites have high $\mathrm{AB}$ degradation efficiency percentages $(>90 \%)$, immobilized Titania composites are preferred over nanostructured Titania composites due to their ease of recovery and reuse, especially in industrial applications.

\subsection{Titania-Based Heterojunctions}

Heterojunction construction is another approach for the modification of Titania and the enhancement of its photocatalytic properties (Marcelino and Amorim, 2019; Li R. et al., 2020). Heterojunctions are constructed by forming a direct contact interface between two different semiconductors (Li R. et al., 2020; Yang et al., 2021). The two semiconductors must have different band gaps, a wide band gap $\left(\mathrm{TiO}_{2}\right)$ and a narrow band gap, with the minimum band gap energy in the visible light region (Marcelino and Amorim, 2019; Li R. et al., 2020). This condition enhances the visible light absorption and photocatalytic activity of the heterojunction (Li R. et al., 2020). Heterojunctions promote the migration of charge carriers (electrons and holes) from one semiconductor to the other and minimize charge carrier recombination (Marcelino and Amorim, 2019; Li R. et al., 2020). Most $\mathrm{TiO}_{2}$-based heterojunctions are binary and can be classified based on the mechanism of separation of $\left(\mathrm{e}^{-}\right) /\left(h^{+}\right)$ pairs: $\mathrm{p}-\mathrm{n}$ heterojunctions; type I (straddling gap); type II (staggered gap); type III (broken gap); and direct Z-scheme heterojunctions (Li R. et al., 2020; Yang et al., 2021). Table 7 summarizes these systems along with their efficiencies for tetracyclines degradation under various visible light irradiations. As shown in Table 7, binary heterojunctions are the most widely applied composites compared to ternary heterojunctions and homojunctions. Although ternary heterojunctions have very good tetracyclines removal efficiencies under visible light compared to binary heterojunctions, they require the use of an additional semiconductor, which involves additional costs.

\subsubsection{Binary $\mathrm{TiO}_{2}-$ Based Heterojunctions}

Binary heterojunctions are composed of two different semiconductors with different band gap energy levels (Marchelek et al., 2016). Conventional binary heterojunctions include type (I), type (II), and type (III) (Low et al., 2017). Nonconventional binary heterojunctions include $\mathrm{p}$ - $\mathrm{n}$ heterojunctions and $\mathrm{Z}$-scheme heterojunctions ( $\mathrm{Li}$ R. et al., 2020). The various conduction and valence level arrangements and mechanisms of these heterojunction catalysts are detailed in the following references (Low et al., 2017; Li R. et al., 2020).

Examples of binary $\mathrm{TiO}_{2}$-based heterojunctions include $\mathrm{TiO}_{2} / \mathrm{BiOCl}\left(\mathrm{Hu}\right.$ et al., 2019) and $\boldsymbol{a}-\mathrm{Fe}_{2} \mathrm{O}_{3} @ \mathrm{TiO}_{2}$ (Zheng et al., 2018). The $a-\mathrm{Fe}_{2} \mathrm{O}_{3} @ \mathrm{TiO}_{2}$ is a type (I) heterojunction where the covalent bond (CB) of the first semiconductor $\left(\mathrm{TiO}_{2}\right)$ exists at a higher position than the $\mathrm{CB}$ of the second semiconductor $\left(\mathrm{Fe}_{2} \mathrm{O}_{3}\right)$, but the valence bond ( $\left.\mathrm{VB}\right)$ of $\mathrm{Fe}_{2} \mathrm{O}_{3}$ is above that of $\mathrm{TiO}_{2}$. In this type, electrons move from the semiconductor with lower $\mathrm{CB} \quad\left(\alpha-\mathrm{Fe}_{2} \mathrm{O}_{3}\right)$ into the semiconductor with higher $\mathrm{CB}\left(\mathrm{TiO}_{2}\right)$. The $\alpha-\mathrm{Fe}_{2} \mathrm{O}_{3} @ \mathrm{TiO}_{2}$ catalyst resulted in (100\%) tetracycline hydrochloride degradation efficiency and (98\%) TOC removal efficiency in 


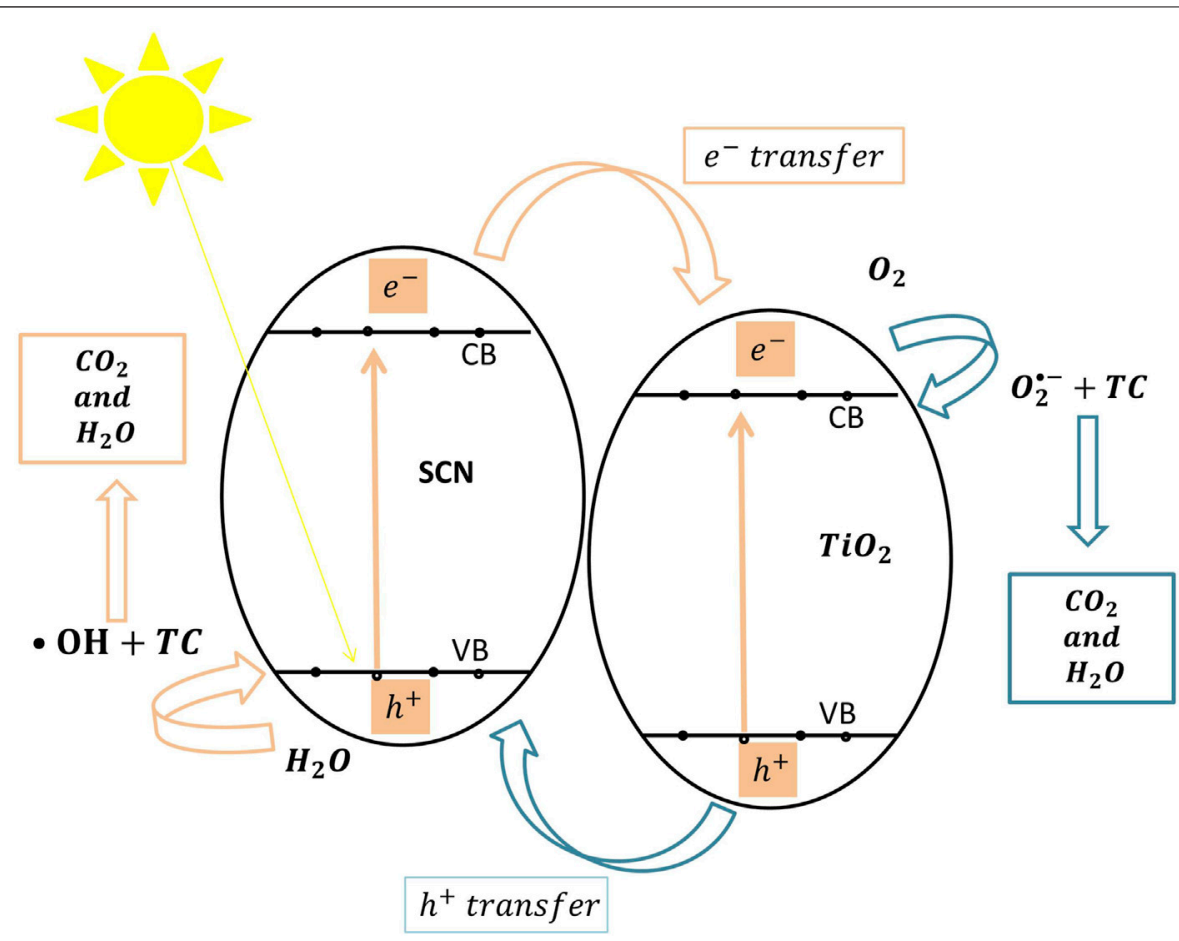

FIGURE 6|The proposed photocatalytic degradation mechanism of tetracycline by $\mathrm{TiO}_{2} @$ sulfur doped carbon nitride nanocomposite catalyst classified as type (II) heterojunction under visible light.

only 120 min using a $300 \mathrm{~W}$ xenon lamp (Zheng et al., 2018). The proposed mechanism for the degradation of tetracycline hydrochloride over the $\mathrm{Fe}_{2} \mathrm{O}_{3} @ \mathrm{TiO}_{2}$ includes reduction/ oxidation reactions by electron/hole pairs followed by the formation of the radicals (Eqs 2, 3, 7, 8, 9, 10) necessary for tetracycline hydrochloride degradation (Eqs 4, 5, 6).

The $\mathrm{TiO}_{2}$-coated cubic $a-\mathrm{Fe}_{2} \mathrm{O}_{3}$ core-shell heterojunction was synthesized using the hydrothermal method. The excellent visible light performance of the catalyst was primarily attributed to the well-matched interface between the cubic $\alpha-\mathrm{Fe}_{2} \mathrm{O}_{3}$ and $\mathrm{TiO}_{2}$ shell, the low band gap energy $(1.97 \mathrm{eV})$, and enhanced visible light harvesting. The $\alpha-\mathrm{Fe}_{2} \mathrm{O}_{3} @$ $\mathrm{TiO}_{2}$ also had enhanced electron transfer through the heterojunction interface, better charge carrier separation, and minimized electron/hole recombination. The $\alpha-\mathrm{Fe}_{2} \mathrm{O}_{3} @ \mathrm{TiO}_{2}$ maintained excellent degradation efficiency (95\%) and stability even after the fifth use. The authors reported that the core-shell structure of the $\mathrm{TiO}_{2}$ shell and the cubic morphology of $a-\mathrm{Fe}_{2} \mathrm{O}_{3}$ core led to an enhanced electron transfer and minimized electron/hole recombination effect.

Several studies have investigated type (II) $\mathrm{TiO}_{2}$-based binary heterojunctions. $\mathrm{TiO}_{2} @$ sulfur doped carbon nitride nanocomposite reported by Divakaran et al. (Divakaran et al., 2021) and $\mathrm{TiO}_{2} / \mathrm{SnNb}_{2} \mathrm{O}_{6}$ nanosheet reported by Jin et al. (Jin et al., 2017) are examples of this type of binary heterojunctions. In type (II), the $\mathrm{CB}$ and $\mathrm{VB}$ of the first semiconductor (sulfur doped carbon nitride: SCN) are higher than the corresponding $\mathrm{CB}$ and $\mathrm{VB}$ of the second semiconductor $\left(\mathrm{TiO}_{2}\right)$ (Figure 6). This leads to significant charge carrier separation because excited electrons migrate to the second semiconductor and the positive holes move into the first semiconductor. $\mathrm{TiO}_{2} @$ sulfur doped carbon nitride nanocomposite achieved (98.1\%) degradation efficiency of the initial tetracycline concentration in $60 \mathrm{~min}$, and the $\mathrm{TiO}_{2} / \mathrm{SnNb}_{2} \mathrm{O}_{6}$ nanosheet achieved (75.5\%) degradation efficiency of tetracycline hydrochloride. Additionally, Gong et al. (Gong et al., 2018) applied Z-scheme $\mathrm{CdTe} / \mathrm{TiO}_{2}$ heterojunction which was able to degrade $(78 \%)$ of the initial tetracycline hydrochloride concentration after $30 \mathrm{~min}$. A Z-scheme heterojunction has the same $\mathrm{CB}$ and $\mathrm{VB}$ arrangements of type (II) heterojunction with totally different electron migration route between the first and second semiconductors (Low et al., 2017; Li R. et al., 2020). Upon photo-excitation of electrons, the photo-generated electrons in the second semiconductor combine with the positive holes in the first semiconductor. Consequently, these electron/hole pairs generate the reactive radicals via (Eqs 2, 3, 7, 8, 9, 10) which themselves degrade the TC into $\mathrm{CO}_{2}$ and $\mathrm{H}_{2} \mathrm{O}$ via (Eqs 4, 5, 6).

Liao et al. (Liao et al., 2021) prepared a binary p-n junction using $\mathrm{BiFeO}_{3} / \mathrm{TiO}_{2}$ catalyst, and reported a (72.2\%) tetracycline degradation efficiency after $180 \mathrm{~min}$. This catalyst is composed of p-type and n-type semiconductors separated by a charged space region around the interface known as an internal electric field. This electric field minimizes charge carrier recombination by accelerating migration of the excited electrons and positive holes into the $\mathrm{CB}$ of the n-type semiconductor and $\mathrm{VB}$ of the p-type semiconductor, respectively (Low et al., 2017). In the mechanism 


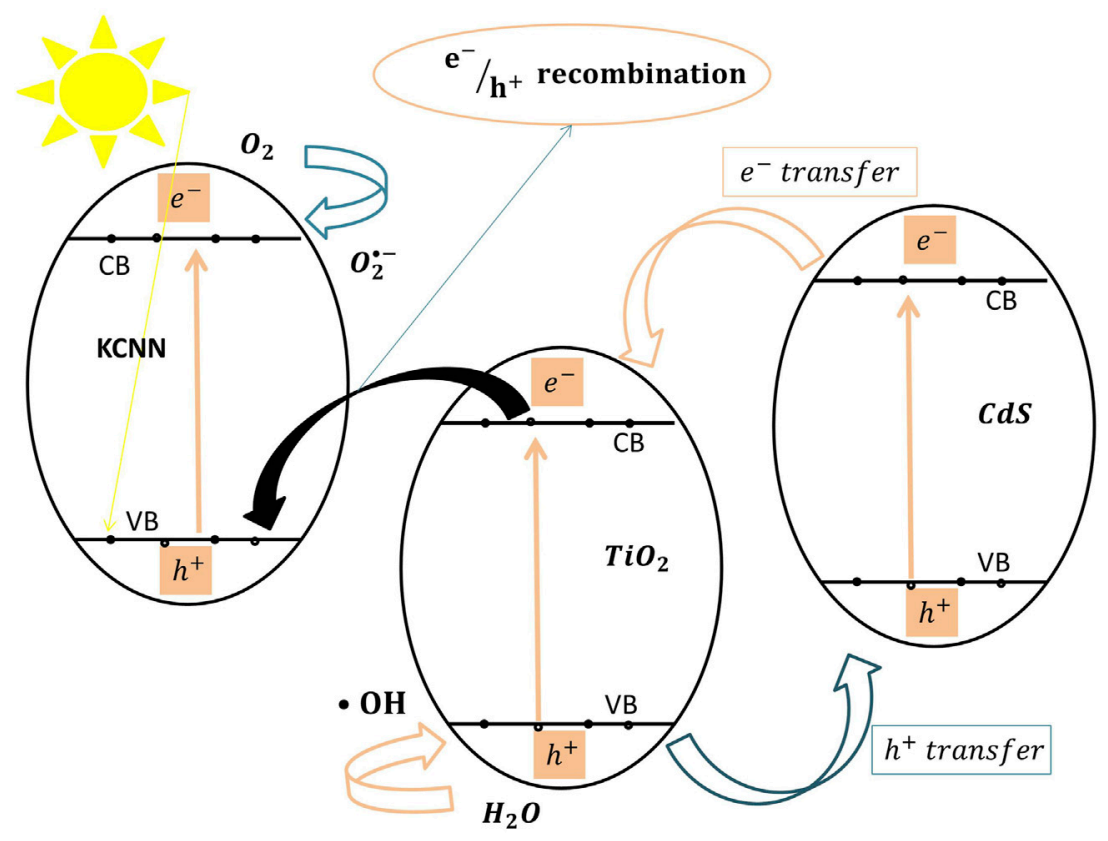

FIGURE 7 | The proposed photocatalytic degradation mechanism of tetracycline by the KCNNT@CdS ternary heterojunction catalyst under visible light.

proposed by Liao et al., excited electrons in the $\mathrm{CB}$ of $\mathrm{BiFeO}_{3}$ move into the $\mathrm{CB}$ of n-type $\mathrm{TiO}_{2}$ semiconductor and similarly the positive holes in the $\mathrm{VB}$ of $\mathrm{BiFeO}_{3}$ move into $\mathrm{VB}$ of n-type $\mathrm{TiO}_{2}$ ensuring minimized recombination effect of $\left(h^{+}\right) /\left(\mathrm{e}^{-}\right)$. The rapid migration of the charge carriers in this catalyst is mainly due to the ferroelectric effect of $\mathrm{BiFeO}_{3}$. While $\left(h^{+}\right)$oxidizes water molecules into hydroxyl radicals, $\left(\mathrm{e}^{-}\right)$reduces adsorbed oxygen molecules into super oxide radicals (Eqs 2, 3, 7, 8, 9, 10). Tetracycline molecules are photocatalytically degraded by these radicals under visible light according to (Eqs 4, 5, 6).

\subsubsection{Ternary $\mathrm{TiO}_{2}$-Based Heterojunctions}

Ternary heterojunctions are composed of three coupled semiconductors to form a ternary contact interface, which enhances electron excitation and photo-efficiency (Marchelek et al., 2016). Liu et al. (Liu et al., 2021) used the hydrothermal method to construct a novel ternary composite heterojunction with superior photocatalytic properties, which consisted of a synthesized K-doped g- $\mathrm{C}_{3} \mathrm{~N}_{4} / \mathrm{TiO}_{2} / \mathrm{CdS}$ (KCNNT@CdS) ternary heterojunction nanocomposite. This nanocomposite photocatalyst was tested for tetracycline degradation efficiency under visible light using a $300 \mathrm{~W}$ xenon lamp. This photocatalyst showed excellent visible light-induced tetracycline degradation efficiency (94.2\%) as compared to that of unmodified $\mathrm{TiO}_{2}$ (69.47\%). KCNNT@CdS degraded (40.1\%) of the initial TOC concentration after $30 \mathrm{~min}$. The authors attributed this performance enhancement to the presence of $\mathrm{CdS}$, which behaved as an electron supplier and promoted charge carrier separation. The presence of $\mathrm{TiO}_{2}$ itself was crucial to enhance the adsorption of tetracycline molecules on the surface of the composite KCNNT@CdS. The $\mathrm{K}$ dopant on the $\mathrm{g}-\mathrm{C}_{3} \mathrm{~N}_{4}$ nanosheet enhanced visible light absorption, and the nanostructured morphology of $\mathrm{g}-\mathrm{C}_{3} \mathrm{~N}_{4}$ minimized charge carrier recombination and enhanced electron transfer (Liu et al., 2020). KCNNT@CdS maintained excellent stability after four uses. Figure 7 shows the photocatalytic degradation mechanism of the KCNNT@CdS ternary heterojunction system. In this proposed mechanism, CdS behaves as an electron provider for $\mathrm{TiO}_{2}$ because all excited electrons of $\mathrm{CdS}$ migrate into the $\mathrm{CB}$ of $\mathrm{TiO}_{2}$ and then move into the $\mathrm{VB}$ of KCNN to combine with the positive holes. Specifically $(\bullet \mathrm{OH}),\left(h^{+}\right)$, and $\left(\mathrm{O}_{2}^{\bullet-}\right)$, generated according to (Eqs 2, 3, 7, 8, 9, 10) are critical for tetracycline degradation under visible light irradiation.

Immobilized $\mathrm{TiO}_{2}$-based heterojunction systems offer easy catalyst recovery. Carbonaceous nanomaterials function as catalyst supports and can form a heterojunction with $\mathrm{TiO}_{2}$ at the molecular level, thereby generating a ternary heterojunction. The nanocarbon material in the ternary heterojunction participates in the photocatalytic degradation process by controlling the electron transfer mechanism (Scaria et al., 2020). Liu et al. (Liu M. et al., 2019) prepared a ternary carbon plane/g- $\mathrm{C}_{3} \mathrm{~N}_{4} / \mathrm{TiO}_{2}$ nanocomposite heterojunction by anchoring the carbon plane into $\mathrm{g}-\mathrm{C}_{3} \mathrm{~N}_{4}$ and then coupling it with $\mathrm{TiO}_{2}$, and they tested it for tetracycline degradation under visible light using a $500 \mathrm{~W}$ xenon lamp. The authors reported that the presence of the carbon plane was necessary to form the required ternary heterojunction contact in the prepared carbon plane/g- $\mathrm{C}_{3} \mathrm{~N}_{4} / \mathrm{TiO}_{2}$ nanostructured catalyst. The carbon plane/ g- $\mathrm{C}_{3} \mathrm{~N}_{4} / \mathrm{TiO}_{2}$ photocatalyst degraded $(94.0 \%)$ of the initial tetracycline concentration, whereas unmodified $\mathrm{TiO}_{2}$ only degraded (46\%) of the tetracycline. This improved visible light activity of the photocatalyst was ascribed to the heterojunction structure with effective ternary contact that enhanced charge carrier separation and transfer, and the inhibited charge carrier recombination. 


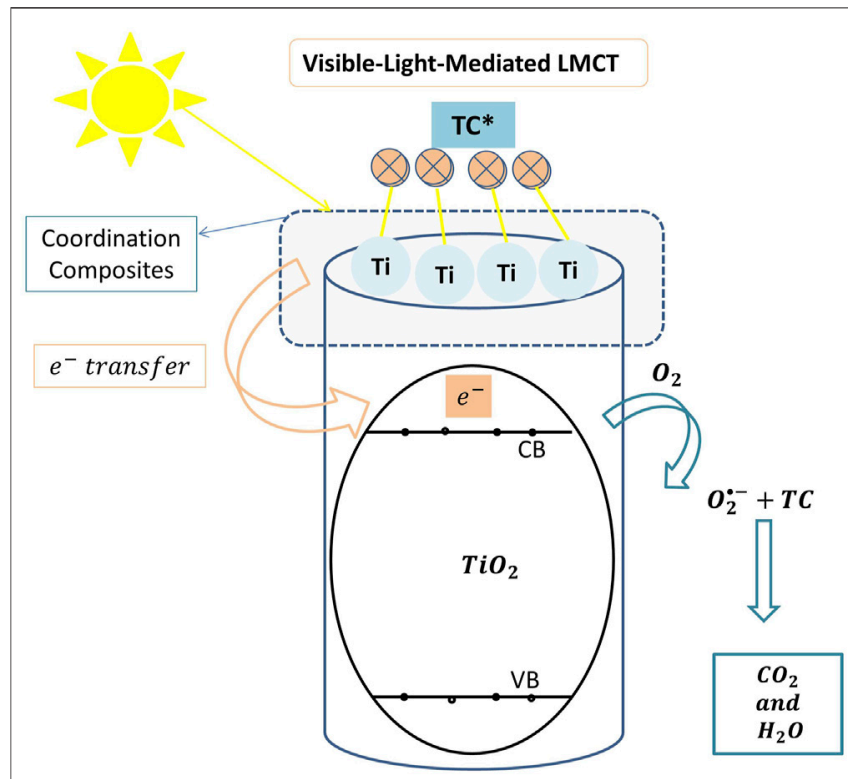

FIGURE 8 | The proposed photocatalytic degradation mechanism of tetracycline by the $\mathrm{TiO}_{2}$ hollow sphere $(001-\mathrm{HT})$ facet heterojunction catalyst under visible light.

\subsection{3 $\mathrm{TiO}_{2}$-Based Homogenous Facet Junctions}

Homogenous facet junctions are composed of different crystal planes of the same semiconductor in the same catalyst particle. The exposed surfaces generate a synergistic effect that enables local redox reactions and enhances charge separation and photoexcitation of the electrons (Yang et al., 2021). Zhang et al. (Zhang S. et al., 2020) prepared a homogeneous facet junction composed of $\{101\}$ and $\{001\}$ facets that were coexposed to a $\mathrm{TiO}_{2}$ hollow sphere (001-HT) facet heterojunction using a gentle sodium fluoride (NaF) treatment. This catalyst was used for tetracycline degradation under visible light using a $300 \mathrm{~W}$ xenon lamp. The reported tetracycline degradation efficiency of the 001-HT facet heterojunction photocatalyst $(90.1 \%)$ was higher than that of the $\{101\}$ facet-exposed $\mathrm{TiO}_{2}$ hollow sphere (HT) that was obtained without $\mathrm{NaF}$ treatment (80\%). The authors attributed the improved photocatalytic degradation of 001 HT to the formation of a $\{101\} /\{001\}$ facet heterojunction, which enhanced visible light absorption, extended the life of excited electrons, increased charge carrier migration, and minimized charge carrier recombination. The enhanced visible light absorption of 001-HT was attributed to ligandto-metal charge transfer (LMCT) due to the formation of coordination complexes between tetracycline molecules and $\mathrm{Ti}$ (IV) ions (Figure 8). Higher surface area, larger pore diameter, rougher surface, and bigger crystalline grains were reported for (001-HT) as compared to (HT). The photogenerated electrons in the highest occupied molecular orbital (HOMO) of the tetracycline antibiotic migrate into the $\mathrm{CB}$ of $\mathrm{TiO}_{2}$ hollow sphere while no electron excitation occurs in $\mathrm{TiO}_{2}$. The transferred electrons reduce the oxygen molecules into super oxide radicals which attack the tetracycline molecules in the aqueous medium and convert them into $\mathrm{H}_{2} \mathrm{O}$ and $\mathrm{CO}_{2}$ (Eqs 4, 5, 6).

\subsection{Recommendations on Most Promising $\mathrm{TiO}_{2}$ Systems for Tetracyclines Degradation}

In summary, all previous studies investigating Titania modifications clearly indicate that a combination of more than one modification method is crucial to achieve superior properties of photoactivity, stability, and ease of recovery for practical applications of the catalyst. For example, metal/nonmetal doping can enhance the visible light absorption of Titania; however, further immobilization of the doped $\mathrm{TiO}_{2}$ through the formation of composite systems is essential to enhance catalyst morphology, photocatalytic properties, and stability. In metal/nonmetal doping, optimal dopant concentrations are recommended to prevent excess charge carriers, which can promote charge carrier recombination (Sponza and Koyuncuoglu, 2019; Zhang et al., 2019). The construction of heterojunction composites through the formation of a direct interface between Titania and another semiconductor enhances $\mathrm{TiO}_{2}$ photocatalytic properties by improving the migration rate of charge carriers (i.e., both electron and positive holes) and minimizing their recombination. However, large-scale application of heterojunction photocatalysts is limited due to the complexity of fabrication, high cost, and low recycling efficiency (Li R. et al., 2020; Yang et al., 2021). A conclusion on the optimal modification method requires a complete understanding of the thermodynamics of the surface redox reactions and reaction mechanisms (Basavarajappa et al., 2020).

Based on our literature review, the best performing systems include 1) $\mathrm{TiO}_{2}$ nanobelts modified with $\mathrm{Au}$ and $\mathrm{CuS}$ nanoparticles composite (Chen et al., 2016) which degraded (96\%) of the initial oxytetracycline concentration in $60 \mathrm{~min}$, indicating excellent degradation efficiency compared to other composites; 2) $\mathrm{N}$-doped $\mathrm{TiO}_{2} / \mathrm{rGO}$ composites (Tang et al., 2018) that exhibited superior activity, with (98\%) tetracycline hydrochloride degradation efficiency in $60 \mathrm{~min}$ due to $\mathrm{N}$-doping and the addition of the rGO support; 3) $\mathrm{Fe}_{2} \mathrm{O}_{3}$ $\mathrm{TiO}_{2}$ /modified zeolite composite (Liu M. et al., 2019), which also exhibited $98 \%$ oxytetracycline degradation in $60 \mathrm{~min}$. We recommend the following $\mathrm{TiO}_{2}$ modifications to be further considered in future studies for the photocatalytic degradation of TCs and antibiotics in irrigation water:

- Non-metal doping of Titania (C and N) to enhance its activity under visible light, to achieve high stability, and to avoid toxic metal leaching in case of metal doping (Sections 5.1.2, 5.2.2, 5.3.1) (Palanivelu et al., 2007; Teoh et al., 2012; Wu et al., 2013; Marschall and Wang, 2014; Chen and Liu, 2016; Oseghe and Ofomaja, 2018a; Zhang T. et al., 2020; Li C. et al., 2020; Ghoreishian et al., 2020; Wu et al., 2020).

- Metal doping of Titania or composite formation using nontoxic and ferromagnetic element such as iron to enhance its visible light performance and facilitate its recovery in largescale applications by external magnets due to the acquired 
ferromagnetic property (Section 5.2.1) (Cao et al., 2016; Wang W. et al., 2017; Chen and Liu, 2017).

- Immobilization of the doped Titania on non-toxic supports such as carbonaceous materials to minimize recovery and maintenance costs in commercial applications and improve degradation efficiency (Sections 5.2.1, 5.3.2) (Cao et al., 2016; Zhang S. et al., 2017; Zhang F. J. et al., 2017; Tang et al., 2018; Liu C. et al., 2019; Fang et al., 2019; Jamali Alyani et al., 2019; Koe et al., 2019; Scaria et al., 2020).

- Formation of doped-Titania nanostructured composites (nanosheets, nanowires, nanobelts) that enhances the catalyst's surface area and performance and facilitates its recovery and reuse in industrial scale systems (Section 5.2.2) (Choi et al., 2014; Chen et al., 2016; Bahadar Khan and Kalsoom, 2019; Lyu et al., 2019; Li C. et al., 2020).

- Optimization of the synthesis procedures and immobilization steps of the $\mathrm{TiO}_{2}$ to ensure high and stable efficiency upon continuous reuse and to facilitate the recovery of the deactivated catalyst for proper and safe disposal (Sponza and Koyuncuoglu, 2019; Zhang et al., 2019; Scaria et al., 2020). - Avoid the construction of complex and expensive heterojunction Titania photocatalysts of low recyclability, because this will create additional costs in large-scale systems and thus lower the overall cost efficiency of the proposed system (Li R. et al., 2020; Yang et al., 2021).

\section{THE ENVIRONMENTAL IMPACT OF THE $\mathrm{TIO}_{2}$ MODIFIED SYSTEMS}

The environmental impact of the materials used in $\mathrm{TiO}_{2}$ modification should be considered during the development of visible light-activated $\mathrm{TiO}_{2}$ based photocatalysts. Safe materials with low toxicity and durable supports should be employed for catalyst immobilization to reduce the release of metals and generating secondary pollutants. These considerations will protect the environment and minimize the costs of system maintenance and catalyst recovery (Marcelino and Amorim, 2019; Li R. et al., 2020). Another important aspect is the leaching of any of these materials, used for $\mathrm{TiO}_{2}$ modification, into the water medium and eventually into the environment. Usually researchers investigate catalyst recovery and reuse without presenting a study on the possibility of leaching of these materials (Yang et al., 2017). Nevertheless, and specifically in metal doping of $\mathrm{TiO}_{2}$, some researechers did present leaching studies. For example, Wang et al. studied the leaching of $\mathrm{Fe}$ ions from $\mathrm{Fe}_{3} \mathrm{O}_{4} / \mathrm{rGO} / \mathrm{TiO}_{2}$ when used for the degradation of tetracycline hydrochloride. The authors reported only $0.5 \mathrm{mg} / \mathrm{L}$ of $\mathrm{Fe}$ leaching into the soution, during the first cycle of catalyst use, which they concluded to be negligible. Moreover, after five cylcels of use (Wang W. et al., 2017), the samples were characterized by XRD and FTIR and no structrual changes were detected, confirming the textural and structural stability of the $\mathrm{Fe}_{3} \mathrm{O}_{4} / \mathrm{rGO} / \mathrm{TiO}_{2}$ catalyst. For the $\mathrm{CeO}_{2} / \mathrm{TiO}_{2}$ binary heterojunction, Pudukudy et al. (Pudukudy et al., 2020) confirmed using FESEM elemental mapping, no Ce leaching after the $7^{\text {th }}$ use of the catalyst. Similarly, Bi et al. reported that the leached percentages of $\mathrm{Mn}$ and $\mathrm{Co}$ metals from $\mathrm{MnCo}_{2} \mathrm{O}_{4.5} / \mathrm{TiO}_{2}$ catalyst were in the range (4-10\%). However, it was concluded that leaching reduced the degradation efficiency of TC by only 2.9\% after five runs (Bi et al., 2020).

In general, the stability of the catalyst and the leaching probability would very much depend on the water medium and the photocatalytic degradation conditions, such as the $\mathrm{pH}$ (Yang et al., 2017). Therefore, in real irrigation water media, it may be expected to have more pronounced leaching of the various used elements compared to laboratory distilled water media. In fact, immobilizing the catalyst on carbonaceous materials like graphene can help minimize metal leaching from titania catalysts (Scaria et al., 2020). Although, as mentioned in the above examples, metal leaching does not seem to be significant in photocatalysis, researchers should study and report the leaching of any of the catalyst's components during a photocatalytic degradation reaction using analytical techniques such as atomic absorbance spectroscopy and/or inductively coupled plasma (Marcelino and Amorim, 2019). In general, catalysts that may lead to leaching and further polluting and toxifying the water streams should be avoided, to prevent the need for a further water purification step (Bhadouria et al., 2020).

\section{CONCLUSIONS AND FUTURE RESEARCH}

There is clear evidence for antibiotic contamination of global ecosystems, water, and edible crops. The level of antibiotic contamination depends on the regional production and consumption of these pharmaceuticals. The use of wastewater in irrigation, animal manure, and biosolids in agriculture are important routes for the introduction of $\mathrm{ABs}$ into the ecosystem and edible crops. Current technologies for removing/degrading these pharmaceuticals from wastewater, such as conventional methods (biological processes, coagulation, flocculation, sedimentation, and filtration) and membrane methods, are incapable of removing these low-level and persistent organic pollutants from water. The development of innovative and efficient removal/degradation methods is urgently needed. Photocatalytic degradation is a promising method for removing organic pollutants from wastewater before using it for crop irrigation. This review summarized the current knowledge of Titania modification for the photocatalytic removal/degradation of tetracyclines from water. Titania is the most promising and studied semiconductor in this technology due to its low cost, high stability, low toxicity, good activity, and ease of modification (Teoh et al., 2012; Ibhadon and Fitzpatrick, 2013; Koe et al., 2019; You et al., 2019; Zhang et al., 2019). We recommend that a combination of methods is essential to achieve superior catalytic properties of photoactivity, stability, and ease of recovery; these methods include metal-nonmetal doping, construction of a heterojunction interface with a second semiconductor, and immobilization on a stable porous support.

The large-scale application of the proposed visible light active Titania for irrigation water is plausible, however, there still 
remain many challenges to bring this into application. One of the primary challenges is that the efficiency of these photocatalytic systems in large scale applications remains limited due to various reasons. One of these is the low and non-uniform light transmission into the catalyst surface (Tong et al., 2012). This limitation can be overcome by optimizing the various components of the reaction medium including the photocatalyst, the light illumination, and the reactor design to develop a commercial system for irrigation water treatment ( $\mathrm{Li}$ and Shi, 2016). Moreover, further research is required to enhance the activation of the photocatalyst over a wide range of wavelengths, including the visible light region. It is also necessary to improve the overall mineralization and quantum efficiencies and the ease of recyclability and reusability of these photocatalysts (Tong et al., 2012). A complete mineralization of the toxic organic compounds is essential to minimize the formation of byproducts, which in some cases could be more toxic than the initial pollutant (Section 4.1) (Calvete et al., 2019). Most of the studies discussed in this review lacked toxicity assessments of intermediate photoproducts. We recommend that researchers conduct toxicity studies along with studies of catalyst performance.

In addition, it is worth noting that most research on the modification of Titania and other semiconductors for $\mathrm{AB}$ degradation utilize laboratory-scale reactors containing synthetic solutions of antibiotics in distilled water rather than in real wastewater irrigation samples. However, the observed catalyst efficiency in these laboratory systems is an overestimate and does not reflect the real-world efficiency of the catalyst in contaminated water samples. Similarly, catalyst recovery in large-scale applications is expected to be more challenging than it is in small-scale laboratory experiments ( $\mathrm{Li} \mathrm{R}$. et al., 2020).

To conclude, we recommend that further research is needed to bring Titania-based photocatalytic degradation of ABs into large scale application. An efficient and easily recyclable catalyst system should be coupled with an optimum reactor design and adequate light source to guarantee a feasible large scale application.

As for the impact on humans, we conclude that human consumption of $\mathrm{AB}$-contaminated water and edible crops leads to health risks because it can potentiate antibiotic resistance in human pathogens. A clear assessment of the risks imposed by

\section{REFERENCES}

Abi Khalil, P. F. (2008). Quantification of Antibiotic Residue Levels and Determination of Antimicrobial Resistance Profiles of Microorganisms Isolated from Raw Milk in Lebanon-by Pamela Fouad Abi Khalil in Dept. Of Nutrition and Food Science. Lebanon: American University of Beirut (AUB).

Adams, C., Wang, Y., Loftin, K., and Meyer, M. (2002). Removal of Antibiotics from Surface and Distilled Water in Conventional Water Treatment Processes. J. Environ. Eng. 128 (3), 253-260. doi:10.1061/(asce)0733-9372(2002)128: $3(253)$

Addamo, M., Augugliaro, V., Di Paola, A., García-López, E., Loddo, V., Marcì, G., et al. (2005). Removal of Drugs in Aqueous Systems by Photoassisted Degradation. J. Appl. Electrochemistry 35 (7), 765-774. doi:10.1007/s10800005-1630-y antibiotic contaminants on human health is lacking. The ecotoxicological effects of using antibiotic-contaminated irrigation water and/or animal manure fertilizer have not been fully investigated and understood. This would require a clear understanding of the physiochemical properties of the antibiotics in the soil and the mechanisms of their translocation and bioaccumulation in plants (Pan and Chu, 2017). Field studies are required to accurately assess antibiotic uptake by various crops under different environmental conditions, and the impacts of antibiotic bioaccumulation in these plants (Pan and Chu, 2017).

Well-defined dietary studies are urgently needed to evaluate the impact of consumption of antibiotic-contaminated crops from real-world fields on human health (Pan and Chu, 2017). These studies should include participants of different ages consuming different edible crops planted in soil treated with different concentrations of animal manure and irrigated with antibiotic-containing wastewater.

\section{AUTHOR CONTRIBUTIONS}

Conceptualization, CB; writing-original draft; GJ and IK; Review and editing; $\mathrm{CB}$ and AT; Supervision, $\mathrm{CB}$; funding acquisition; $\mathrm{CB}$ and AT. All authors have read and agreed to the published version of the manuscript.

\section{FUNDING}

Funding was provided by the WEFRAH (Water-Energy-FoodHealth Nexus) initiative at the American University of Beirut (Project number: 25202, Award number: 103763).

\section{ACKNOWLEDGMENTS}

The authors gratefully acknowledge the financial support provided by the WEFRAH initiative at the American University of Beirut. The authors greatly thank and acknowledge the scientific contribution of Prof. Isam Bashour, at the Faculty of Agriculture and Food Sciences at the American University of Beirut.

Akel, S., Boughaled, R., Dillert, R., El Azzouzi, M., and Bahnemann, D. W. (2020). UV/Vis Light Induced Degradation of Oxytetracycline Hydrochloride Mediated byCo-TiO2 Nanoparticles. Molecules 25 (2), 249. doi:10.3390/ molecules 25020249

Andreozzi, R., Canterino, M., Marotta, R., and Paxeus, N. (2005). Antibiotic Removal from Wastewaters: The Ozonation of Amoxicillin. J. Hazard. Mater. 122 (3), 243-250. doi:10.1016/j.jhazmat.2005.03.004

Anjali, R., and Shanthakumar, S. (2019). Insights on the Current Status of Occurrence and Removal of Antibiotics in Wastewater by Advanced Oxidation Processes. J. Environ. Manage. 246, 51-62. doi:10.1016/j.jenvman.2019.05.090

Arif, Z., Sethy, N. K., Kumari, L., Mishra, P. K., and Upadhyay, S. N. (2020). "Recent Advances in Functionalized Polymer-Based Composite Photocatalysts for Wastewater Treatment," in Nano-Materials as Photocatalysts for Degradation of Environmental Pollutants. Editor P. Singh (Elsevier), 39-64. doi:10.1016/b978-0-12-818598-8.00003-1 
Arslan-Alaton, I., and Dogruel, S. (2004). Pre-treatment of Penicillin Formulation Effluent by Advanced Oxidation Processes. J. Hazard. Mater. 112 (1), 105-113. doi:10.1016/j.jhazmat.2004.04.009

Azanu, D., Mortey, C., Darko, G., Weisser, J. J., Styrishave, B., and Abaidoo, R. C. (2016). Uptake of Antibiotics from Irrigation Water by Plants. Chemosphere 157, 107-114. doi:10.1016/j.chemosphere.2016.05.035

Bahadar Khan, S., and Kalsoom, A. (2019). "Modified Titanium Dioxide for Photocatalytic Applications," in Photocatalysts - Applications and Attributes.

Bao, S., Liu, H., Liang, H., Li, C., and Bai, J. (2021). Electrospinned Silk-ribbon-like Carbon-Doped TiO2 Ultrathin Nanosheets for Enhanced Visible-Light Photocatalytic Activity. Colloids Surf. A: Physicochemical Eng. Aspects 616, 126289. doi:10.1016/j.colsurfa.2021.126289

Basavarajappa, P. S., Patil, S. B., Ganganagappa, N., Reddy, K. R., Raghu, A. V., and Reddy, C. V. (2020). Recent Progress in Metal-Doped TiO2, Non-metal Doped/ codoped TiO2 and TiO2 Nanostructured Hybrids for Enhanced Photocatalysis. Int. J. Hydrogen Energ. 45 (13), 7764-7778. doi:10.1016/j.ijhydene.2019.07.241

Bautitz, I. R., and Nogueira, R. F. P. (2010). Photodegradation of Lincomycin and Diazepam in Sewage Treatment Plant Effluent by Photo-Fenton Process. Catal. Today 151 (1), 94-99. doi:10.1016/j.cattod.2010.02.018

Bhadouria, R., Mishra, D., Singh, V. K., Singh, P., Srivastava, P., Tripathi, S., et al. (2020). "Nanocatalyst Types and Their Potential Impacts in Agroecosystems: An Overview," in Nano-Materials as Photocatalysts for Degradation of Environmental Pollutants. Editor P. Singh (Elsevier), 323-344. doi:10.1016/ b978-0-12-818598-8.00016-x

Bi, Y., Li, J., Dong, C., Mu, W., and Han, X. (2020). Rational Construction of MnCo 2 O 4.5 Deposited TiO 2 Nanotube Array Heterostructures with Enhanced Photocatalytic Degradation of Tetracycline. ChemPhotoChem 4 (5), 366-372. doi:10.1002/cptc.201900283

Bouafia-Chergul, S., Zemmourı, H., Chabanı, M., and Bensmall, A. (2016). $\mathrm{TiO}_{2^{-}}$ photocatalyzed Degradation of Tetracycline: Kinetic Study, Adsorption Isotherms, Mineralization and Toxicity Reduction. Desalination Water Treat. 57 (35), 16670-16677. doi:10.1080/19443994.2015.1082507

Calvete, M. J. F., Piccirillo, G., Vinagreiro, C. S., and Pereira, M. M. (2019). Hybrid Materials for Heterogeneous Photocatalytic Degradation of Antibiotics. Coord. Chem. Rev. 395, 63-85. doi:10.1016/j.ccr.2019.05.004

Cao, M., Wang, P., Ao, Y., Wang, C., Hou, J., and Qian, J. (2016). Visible Light Activated Photocatalytic Degradation of Tetracycline by a Magnetically Separable Composite Photocatalyst: Graphene Oxide/magnetite/ceriumDoped Titania. J. Colloid Interf. Sci. 467, 129-139. doi:10.1016/j.jcis.2016.01.005

Cao, X., Tao, J., Xiao, X., and Nan, J. (2018). Hydrothermal-assisted Synthesis of the Multi-Element-Doped $\mathrm{TiO} 2$ Micro/nanostructures and Their Photocatalytic Reactivity for the Degradation of Tetracycline Hydrochloride under the Visible Light Irradiation. J. Photochem. Photobiol. A: Chem. 364, 202-207. doi:10.1016/j.jphotochem.2018.06.013

Carlesi Jara, C., Fino, D., Specchia, V., Saracco, G., and Spinelli, P. (2007). Electrochemical Removal of Antibiotics from Wastewaters. Appl. Catal. B: Environ. 70 (1), 479-487. doi:10.1016/j.apcatb.2005.11.035

Chen, D., Jiang, Z., Geng, J., Wang, Q., and Yang, D. (2007). Carbon and Nitrogen Co-doped $\mathrm{TiO} 2$ with Enhanced Visible-Light Photocatalytic Activity. Ind. Eng. Chem. Res. 46 (9), 2741-2746. doi:10.1021/ie061491k

Chen, F., Li, D., Luo, B., Chen, M., and Shi, W. (2017). Two-dimensional Heterojunction Photocatalysts Constructed by Graphite-like C3N4 and Bi2WO6 Nanosheets: Enhanced Photocatalytic Activities for Water Purification. J. Alloys Compd. 694, 193-200. doi:10.1016/j.jallcom.2016.09.326

Chen, M., Zhu, M., Zhu, Y., Wang, D., Li, Z., Zeng, G., et al. (2019). Collision of Emerging and Traditional Methods for Antibiotics Removal: Taking Constructed Wetlands and Nanotechnology as an Example. NanoImpact 15, 100175. doi:10.1016/j.impact.2019.100175

Chen, Q., Wu, S., and Xin, Y. (2016). Synthesis of Au-CuS-TiO ${ }_{2}$ Nanobelts Photocatalyst for Efficient Photocatalytic Degradation of Antibiotic Oxytetracycline. Chem. Eng. J. 302, 377-387. doi:10.1016/j.cej.2016.05.076

Chen, W.-R., and Huang, C.-H. (2010). Adsorption and Transformation of Tetracycline Antibiotics with Aluminum Oxide. Chemosphere 79 (8), 779-785. doi:10.1016/j.chemosphere.2010.03.020

Chen, Y., and Liu, K. (2017). Fabrication of Magnetically Recyclable Ce/N Codoped $\mathrm{TiO} 2 / \mathrm{NiFe} 2 \mathrm{O} 4 /$ diatomite Ternary Hybrid: Improved Photocatalytic Efficiency under Visible Light Irradiation. J. Alloys Compd. 697, 161-173. doi:10.1016/j.jallcom.2016.12.153
Chen, Y., and Liu, K. (2016). Preparation and Characterization of Nitrogen-Doped TiO 2/diatomite Integrated Photocatalytic Pellet for the AdsorptionDegradation of Tetracycline Hydrochloride Using Visible Light. Chem. Eng. J. 302, 682-696. doi:10.1016/j.cej.2016.05.108

Chen, Y., Wu, Q., Liu, L., Wang, J., and Song, Y. (2019). The Fabrication of Floating $\mathrm{Fe} / \mathrm{N}$ Co-doped Titania/diatomite Granule Catalyst with Enhanced Photocatalytic Efficiency under Visible Light Irradiation. Adv. Powder Techn. 30 (1), 126-135. doi:10.1016/j.apt.2018.10.014

Chen, Y., Wu, Q., Wang, J., and Song, Y. (2019). Retracted: The Fabrication of Magnetic Recyclable Nitrogen-doped Titanium Dioxide/calcium Ferrite/ diatomite Heterojunction Nanocomposite for Improved Visible-light-driven Degradation of Tetracycline. J. Chem. Technol. Biotechnol. 94 (8), 2702-2712. doi:10.1002/jctb.6082

Choi, H., Zakersalehi, A., Al-Abed, S. R., Han, C., and Dionysiou, D. D. (2014). "Nanostructured Titanium Oxide Film- and Membrane-Based Photocatalysis for Water Treatment," in Nanotechnology Applications for Clean Water. Editor A. Street Second Edition (Oxford: William Andrew Publishing), 123-132. doi:10.1016/b978-1-4557-3116-9.00008-1

Choi, K.-J., Kim, S.-G., and Kim, S.-H. (2008). Removal of Antibiotics by Coagulation and Granular Activated Carbon Filtration. J. Hazard. Mater. 151 (1), 38-43. doi:10.1016/j.jhazmat.2007.05.059

Choi, K. J., Son, H. J., and Kim, S. H. (2007). Ionic Treatment for Removal of Sulfonamide and Tetracycline Classes of Antibiotic. Sci. Total Environ. 387 (13), 247-256. doi:10.1016/j.scitotenv.2007.07.024

Christou, A., Agüera, A., Bayona, J. M., Cytryn, E., Fotopoulos, V., Lambropoulou, D., et al. (2017). The Potential Implications of Reclaimed Wastewater Reuse for Irrigation on the Agricultural Environment: The Knowns and Unknowns of the Fate of Antibiotics and Antibiotic Resistant Bacteria and Resistance Genes - A Review. Water Res. 123, 448-467. doi:10.1016/j.watres.2017.07.004

Daghrir, R., and Drogui, P. (2013). Tetracycline Antibiotics in the Environment: a Review. Environ. Chem. Lett. 11 (3), 209-227. doi:10.1007/s10311-013-0404-8

Danner, M.-C., Robertson, A., Behrends, V., and Reiss, J. (2019). Antibiotic Pollution in Surface Fresh Waters: Occurrence and Effects. Sci. Total Environ. 664, 793-804. doi:10.1016/j.scitotenv.2019.01.406

Demircivi, P., and Simsek, E. B. (2019). Visible-light-enhanced Photoactivity of Perovskite-type W-Doped BaTiO3 Photocatalyst for Photodegradation of Tetracycline. J. Alloys Compd. 774, 795-802. doi:10.1016/j.jallcom.2018.09.354

Deng, Y., Tang, L., Zeng, G., Feng, C., Dong, H., Wang, J., et al. (2017). Plasmonic Resonance Excited Dual Z-Scheme BiVO4/Ag/Cu2O Nanocomposite: Synthesis and Mechanism for Enhanced Photocatalytic Performance in Recalcitrant Antibiotic Degradation. Environ. Sci. Nano 4 (7), 1494-1511. doi:10.1039/c7en00237h

Di, J., Xia, J., Ge, Y., Li, H., Ji, H., Xu, H., et al. (2015). Novel Visible-Light-Driven CQDs/Bi 2 WO 6 Hybrid Materials with Enhanced Photocatalytic Activity toward Organic Pollutants Degradation and Mechanism Insight. Appl. Catal. B: Environ. 168-169, 51-61. doi:10.1016/j.apcatb.2014.11.057

Diao, Y., Yan, M., Li, X., Zhou, C., Peng, B., Chen, H., et al. (2020). In-situ Grown of G-C3N4/Ti3C2/TiO2 Nanotube Arrays on Ti Meshes for Efficient Degradation of Organic Pollutants under Visible Light Irradiation. Colloids Surf. A: Physicochemical Eng. Aspects 594, 124511. doi:10.1016/j.colsurfa.2020.124511

Divakaran, K., Baishnisha, A., Balakumar, V., Perumal, K. N., Meenakshi, C., and Kannan, R. S. (2021). Photocatalytic Degradation of Tetracycline under Visible Light Using TiO2@sulfur Doped Carbon Nitride Nanocomposite Synthesized via In-Situ Method. J. Environ. Chem. Eng. 9 (4), 105560. doi:10.1016/ j.jece.2021.105560

Duan, Y., Zhai, D., Zhang, X., Zheng, J., and Li, C. (2018). Synthesis of CuO/TiMCM-48 Photocatalyst for the Degradation of Organic Pollutions under SolarSimulated Irradiation. Catal. Lett. 148 (1), 51-61. doi:10.1007/s10562-0172258-3

Fang, Y., Li, Y., Zhou, F., Gu, P., Liu, J., Chen, D., et al. (2019). An Efficient Photocatalyst Based on Black TiO 2 Nanoparticles and Porous Carbon with High Surface Area: Degradation of Antibiotics and Organic Pollutants in Water. ChemPlusChem 84 (5), 474-480. doi:10.1002/cplu.201900103

Farhadian, N., Akbarzadeh, R., Pirsaheb, M., Jen, T.-C., Fakhri, Y., and Asadi, A. (2019). Chitosan Modified N, S-Doped TiO2 and N, S-Doped ZnO for Visible Light Photocatalytic Degradation of Tetracycline. Int. J. Biol. Macromolecules 132, 360-373. doi:10.1016/j.ijbiomac.2019.03.217 
Fazilati, M., Nozhat, S., and Borghei, S. M. (2018). "Comparing the Efficiency of $\mathrm{TiO} 2 / \mathrm{ZnO}$ Catalysts in the Removal of Tetracycline from Aqueous Solution," in International Congress on Engineering Science and Sustainable Urban Development, Denmark - Copenhage.

Feng, X., Wang, P., Hou, J., Qian, J., Ao, Y., and Wang, C. (2018). Significantly Enhanced Visible Light Photocatalytic Efficiency of Phosphorus Doped TiO2 with Surface Oxygen Vacancies for Ciprofloxacin Degradation: Synergistic Effect and Intermediates Analysis. J. Hazard. Mater. 351, 196-205. doi:10.1016/j.jhazmat.2018.03.013

Galedari, M., Mehdipour Ghazi, M., and Rashid Mirmasoomi, S. (2019). Photocatalytic Process for the Tetracycline Removal under Visible Light: Presenting a Degradation Model and Optimization Using Response Surface Methodology (RSM). Chem. Eng. Res. Des. 145, 323-333. doi:10.1016/ j.cherd.2019.03.031

Gautam, S., Agrawal, H., Thakur, M., Akbari, A., Sharda, H., Kaur, R., et al. (2020). Metal Oxides and Metal Organic Frameworks for the Photocatalytic Degradation: A Review. J. Environ. Chem. Eng. 8, 103726. doi:10.1016/ j.jece.2020.103726

Ghoreishian, S. M., Ranjith, K. S., Lee, H., Ju, H.-i., Zeinali Nikoo, S., Han, Y.-K., et al. (2020). Hierarchical N-Doped TiO2@Bi2WxMo1-xO6 Core-Shell Nanofibers for Boosting Visible-Light-Driven Photocatalytic and Photoelectrochemical Activities. J. Hazard. Mater. 391, 122249. doi:10.1016/ j.jhazmat.2020.122249

Ghoreishian, S. M., Ranjith, K. S., Lee, H., Park, B., Norouzi, M., Nikoo, S. Z., et al. (2021). Tuning the Phase Composition of $1 \mathrm{D} \mathrm{TiO} 2$ by Fe/Sn Co-doping Strategy for Enhanced Visible-Light-Driven Photocatalytic and Photoelectrochemical Performances. J. Alloys Compd. 851, 156826. doi:10.1016/j.jallcom.2020.156826

Göbel, A., McArdell, C. S., Joss, A., Siegrist, H., and Giger, W. (2007). Fate of Sulfonamides, Macrolides, and Trimethoprim in Different Wastewater Treatment Technologies. Sci. Total Environ. 372 (2), 361-371. doi:10.1016/ j.scitotenv.2006.07.039

Gong, Y., Wu, Y., Xu, Y., Li, L., Li, C., Liu, X., et al. (2018). All-solid-state Z-Scheme $\mathrm{CdTe} / \mathrm{TiO} 2$ Heterostructure Photocatalysts with Enhanced Visible-Light Photocatalytic Degradation of Antibiotic Waste Water. Chem. Eng. J. 350, 257-267. doi:10.1016/j.cej.2018.05.186

Gopal, N. O., Lo, H.-H., Ke, T.-F., Lee, C.-H., Chou, C.-C., Wu, J.-D., et al. (2012). Visible Light Active Phosphorus-Doped TiO2 Nanoparticles: An EPR Evidence for the Enhanced Charge Separation. J. Phys. Chem. C 116 (30), 16191-16197. doi:10.1021/jp212346f

Gothwal, R., and Shashidhar, T. (2015). Antibiotic Pollution in the Environment: A Review. Clean. Soil Air Water 43 (4), 479-489. doi:10.1002/clen.201300989

Gudda, F. O., Waigi, M. G., Odinga, E. S., Yang, B., Carter, L., and Gao, Y. (2020). Antibiotic-contaminated Wastewater Irrigated Vegetables Pose Resistance Selection Risks to the Gut Microbiome. Environ. Pollut. 264, 114752. doi:10.1016/j.envpol.2020.114752

Guinea, E., Brillas, E., Centellas, F., Cañizares, P., Rodrigo, M. A., and Sáez, C. (2009). Oxidation of Enrofloxacin with Conductive-diamond Electrochemical Oxidation, Ozonation and Fenton Oxidation. A Comparison. Water Res. 43 (8), 2131-2138. doi:10.1016/j.watres.2009.02.025

Guo, F., Sun, H., Huang, X., Shi, W., and Yan, C. (2020). Fabrication of TiO2/highCrystalline G-C3n4 Composite with Enhanced Visible-Light Photocatalytic Performance for Tetracycline Degradation. J. Chem. Techn. Biotechnol. 95 (10), 2684-2693. doi:10.1002/jctb.6384

He, X., Nguyen, V., Jiang, Z., Wang, D., Zhu, Z., and Wang, W.-N. (2018). Highlyoriented One-Dimensional MOF-Semiconductor Nanoarrays for Efficient Photodegradation of Antibiotics. Catal. Sci. Technol. 8 (8), 2117-2123. doi:10.1039/c8cy00229k

Hirose, J., Kondo, F., Nakano, T., Kobayashi, T., Hiro, N., Ando, Y., et al. (2005). Inactivation of Antineoplastics in Clinical Wastewater by Electrolysis. Chemosphere 60 (8), 1018-1024. doi:10.1016/ j.chemosphere.2005.01.024

Homem, V., and Santos, L. (2011). Degradation and Removal Methods of Antibiotics from Aqueous Matrices - A Review. J. Environ. Manage. 92 (10), 2304-2347. doi:10.1016/j.jenvman.2011.05.023

Hu, X., Liu, X., Tian, J., Li, Y., and Cui, H. (2017). Towards Full-Spectrum (UV, Visible, and Near-Infrared) Photocatalysis: Achieving an All-Solid-State $\mathrm{Z}$-Scheme between $\mathrm{Ag} 2 \mathrm{O}$ and $\mathrm{TiO} 2$ Using Reduced Graphene Oxide as the
Electron Mediator. Catal. Sci. Technol. 7 (18), 4193-4205. doi:10.1039/ c7cy01349c

Hu, X., Zhang, G., Yin, C., Li, C., and Zheng, S. (2019). Facile Fabrication of Heterogeneous $\mathrm{TiO} 2 / \mathrm{BiOCl}$ Composite with superior Visible-Light-Driven Performance towards $\mathrm{Cr}(\mathrm{VI})$ and Tetracycline. Mater. Res. Bull. 119, 110559. doi:10.1016/j.materresbull.2019.110559

Hu, X., Zhou, Q., and Luo, Y. (2010). Occurrence and Source Analysis of Typical Veterinary Antibiotics in Manure, Soil, Vegetables and Groundwater from Organic Vegetable Bases, Northern China. Environ. Pollut. 158 (9), 2992-2998. doi:10.1016/j.envpol.2010.05.023

Huber, M. M., Canonica, S., Park, G.-Y., and von Gunten, U. (2003). Oxidation of Pharmaceuticals during Ozonation and Advanced Oxidation Processes. Environ. Sci. Technol. 37 (5), 1016-1024. doi:10.1021/es025896h

Huo, P., Zhou, M., Tang, Y., Liu, X., Ma, C., Yu, L., et al. (2016). Incorporation of $\mathrm{N}-\mathrm{ZnO} / \mathrm{CdS} /$ Graphene Oxide Composite Photocatalyst for Enhanced Photocatalytic Activity under Visible Light. J. Alloys Compd. 670, 198-209. doi:10.1016/j.jallcom.2016.01.247

Hussain, S., Naeem, M., Chaudhry, M. N., and Iqbal, M. A. (2016). Accumulation of Residual Antibiotics in the Vegetables Irrigated by Pharmaceutical Wastewater. Expo. Health 8 (1), 107-115. doi:10.1007/s12403-015-0186-2

Ibhadon, A., and Fitzpatrick, P. (2013). Heterogeneous Photocatalysis: Recent Advances and Applications. Catalysts 3 (1), 189-218. doi:10.3390/ catal3010189

Imad Keniar, I. B., Yanni, S., Kharroubi, S., and Abou Jawdah, Y. (2021). Uptake of Gentamicin and Oxytetracycline by Plants Irrigated with Contaminated Irrigation Water. Poster Presentation, UFWH Summit 2021 Available at https://worldfoodcenter.ucdavis.edu/summit2021/posters-presented-viewing.

Jamali Alyani, S., Ebrahimian Pirbazari, A., Esmaeili Khalilsaraei, F., Asasian Kolur, N., and Gilani, N. (2019). Growing Co-doped TiO2 Nanosheets on Reduced Graphene Oxide for Efficient Photocatalytic Removal of Tetracycline Antibiotic from Aqueous Solution and Modeling the Process by Artificial Neural Network. J. Alloys Compd. 799, 169-182. doi:10.1016/j.jallcom.2019.05.175

Jammoul, A., and El Darra, N. (2019). Evaluation of Antibiotics Residues in Chicken Meat Samples in Lebanon. Antibiotics (Basel) 8 (2), 69. doi:10.3390/ antibiotics8020069

Jiao, S., Zheng, S., Yin, D., Wang, L., and Chen, L. (2008). Aqueous Oxytetracycline Degradation and the Toxicity Change of Degradation Compounds in Photoirradiation Process. J. Environ. Sci. 20 (7), 806-813. doi:10.1016/ s1001-0742(08)62130-0

Jin, Y., Jiang, D., Li, D., and Chen, M. (2017). Construction of Ultrafine TiO2 Nanoparticle and SnNb2O6 Nanosheet 0D/2D Heterojunctions with Abundant Interfaces and Significantly Improved Photocatalytic Activity. Catal. Sci. Technol. 7 (11), 2308-2317. doi:10.1039/c7cy00366h

Jo, W.-K., Kumar, S., Isaacs, M. A., Lee, A. F., and Karthikeyan, S. (2017). Cobalt Promoted TiO2/GO for the Photocatalytic Degradation of Oxytetracycline and Congo Red. Appl. Catal. B: Environ. 201, 159-168. doi:10.1016/ j.apcatb.2016.08.022

Khodadoost, S., Hadi, A., Karimi-Sabet, J., Mehdipourghazi, M., and Golzary, A. (2017). Optimization of Hydrothermal Synthesis of Bismuth Titanate Nanoparticles and Application for Photocatalytic Degradation of Tetracycline. J. Environ. Chem. Eng. 5 (6), 5369-5380. doi:10.1016/ j.jece.2017.10.006

Kim, S. H., Shon, H. K., and Ngo, H. H. (2010). Adsorption Characteristics of Antibiotics Trimethoprim on Powdered and Granular Activated Carbon. J. Ind. Eng. Chem. 16 (3), 344-349. doi:10.1016/j.jiec.2009.09.061

Klauson, D., Babkina, J., Stepanova, K., Krichevskaya, M., and Preis, S. (2010). Aqueous Photocatalytic Oxidation of Amoxicillin. Catal. Today 151 (1), 39-45. doi:10.1016/j.cattod.2010.01.015

Koe, W. S., Lee, J. W., Chong, W. C., Pang, Y. L., and Sim, L. C. (2019). An Overview of Photocatalytic Degradation: Photocatalysts, Mechanisms, and Development of Photocatalytic Membrane. Environ. Sci. Pollut. Res. Int. 27, 2522-2565. doi:10.1007/s11356-019-07193-5

Kosutic, K., Dolar, D., Asperger, D., and Kunst, B. (2007). Removal of Antibiotics from a Model Wastewater by RO/NF Membranes. Separat. Purif. Techn. 53 (3), 244-249. doi:10.1016/j.seppur.2006.07.015

Koyuncu, I., Arikan, O. A., Wiesner, M. R., and Riceb, C. (2008). Removal of Hormones and Antibiotics by Nanofiltration Membranes. J. Membr. Sci. 309 (1), 94-101. doi:10.1016/j.memsci.2007.10.010 
Lakhera, S. K., Hafeez, H. Y., Veluswamy, P., Ganesh, V., Khan, A., Ikeda, H., et al. (2018). Enhanced Photocatalytic Degradation and Hydrogen Production Activity of In Situ Grown $\mathrm{TiO}_{2}$ Coupled NiTiO3 Nanocomposites. Appl. Surf. Sci. 449, 790-798. doi:10.1016/ j.apsusc.2018.02.136

Li, C., Hu, R., Lu, X., Bashir, S., and Liu, J. L. (2020). Efficiency Enhancement of Photocatalytic Degradation of Tetracycline Using Reduced Graphene Oxide Coordinated Titania Nanoplatelet. Catal. Today 350, 171-183. doi:10.1016/ j.cattod.2019.06.038

Li, D., and Shi, W. (2016). Recent Developments in Visible-Light Photocatalytic Degradation of Antibiotics. Chin. J. Catal. 37 (6), 792-799. doi:10.1016/s18722067(15)61054-3

Li, J., Liu, K., Xue, J., Xue, G., Sheng, X., Wang, H., et al. (2019). CQDS Preluded Carbon-Incorporated 3D Burger-like Hybrid $\mathrm{ZnO}$ Enhanced Visible-LightDriven Photocatalytic Activity and Mechanism Implication. J. Catal. 369, 450-461. doi:10.1016/j.jcat.2018.11.026

Li, J., Zhou, M., Ye, Z., Wang, H., Ma, C., Huo, P., et al. (2015). Enhanced Photocatalytic Activity of G-C3n4-ZnO/HNT Composite Heterostructure Photocatalysts for Degradation of Tetracycline under Visible Light Irradiation. RSC Adv. 5 (111), 91177-91189. doi:10.1039/c5ra17360d

Li, K., Yediler, A., Yang, M., Schulte-Hostede, S., and Wong, M. H. (2008). Ozonation of Oxytetracycline and Toxicological Assessment of its Oxidation By-Products. Chemosphere 72 (3), 473-478. doi:10.1016/ j.chemosphere.2008.02.008

Li, L., Jinling, S., Baoying, W., Chenglin, D., Ruifen, W., and Bangwen, Z. (2019). A New BiOXs/TiO2 Heterojunction Photocatalyst towards Efficient Degradation of Organic Pollutants under Visible-Light Irradiation. Micro Nano Lett. 14, 911-914. doi:10.1049/mnl.2018.5584

Li, R., Li, T., and Zhou, Q. (2020). Impact of Titanium Dioxide (TiO2) Modification on its Application to Pollution Treatment-A Review. Catalysts 10 (7), 804. doi:10.3390/catal10070804

Li, W., Ding, H., Ji, H., Dai, W., Guo, J., and Du, G. (2018). Photocatalytic Degradation of Tetracycline Hydrochloride via a CdS-TiO2 Heterostructure Composite under Visible Light Irradiation. Nanomaterials 8 (6), 415. doi:10.3390/nano8060415

Li, W., Li, B., Meng, M., Cui, Y., Wu, Y., Zhang, Y., et al. (2019). Bimetallic Au/Ag Decorated TiO2 Nanocomposite Membrane for Enhanced Photocatalytic Degradation of Tetracycline and Bactericidal Efficiency. Appl. Surf. Sci. 487, 1008-1017. doi:10.1016/j.apsusc.2019.05.162

Liao, X., Li, T.-T., Ren, H.-T., Mao, Z., Zhang, X., Lin, J.-H., et al. (2021). Enhanced Photocatalytic Performance through the Ferroelectric Synergistic Effect of P-N Heterojunction $\mathrm{BiFeO} / \mathrm{TiO} 2$ under VisibleLight Irradiation. Ceramics Int. 47 (8), 10786-10795. doi:10.1016/ j.ceramint.2020.12.195

Libralato, G., Lofrano, G., Siciliano, A., Gambino, E., Boccia, G., Federica, C., et al. (2020). "Toxicity Assessment of Wastewater after Advanced Oxidation Processes for Emerging Contaminants' Degradation," in Visible Light Active Structured Photocatalysts for the Removal of Emerging Contaminants. Editors O. Sacco and V. Vaiano (Elsevier), 195-211. doi:10.1016/b978-0-12-8183342.00008-0

Liu, C., Dong, S., and Chen, Y. (2019). Enhancement of Visible-Light-Driven Photocatalytic Activity of Carbon Plane/g-C3N4/TiO2 Nanocomposite by Improving Heterojunction Contact. Chem. Eng. J. 371, 706-718. doi:10.1016/j.cej.2019.04.089

Liu, C., Wu, G., Chen, J., Huang, K., and Shi, W. (2016). Fabrication of a VisibleLight-Driven Photocatalyst and Degradation of Tetracycline Based on the Photoinduced Interfacial Charge Transfer of SrTiO3/Fe2O3 Nanowires. New J. Chem. 40 (6), 5198-5208. doi:10.1039/c5nj03167b

Liu, M., Shuili, Y., Hou, L., and Xiaojun, H. (2019). Removal of Oxytetracycline by $\mathrm{Fe}_{2} \mathrm{O}_{3}-\mathrm{TiO}_{2}$ /modified Zeolite Composites under Visible Light Irradiation. J. Mater. Sci. Mater. Electro. 30, 9087-9096. doi:10.1007/ s10854-019-01052-2

Liu, W., Dai, Z., Liu, Y., Zhu, A., Zhong, D., Wang, J., et al. (2018). Intimate Contacted Two-Dimensional/zero-Dimensional Composite of Bismuth Titanate Nanosheets Supported Ultrafine Bismuth Oxychloride Nanoparticles for Enhanced Antibiotic Residue Degradation. J. Colloid Interf. Sci. 529, 23-33. doi:10.1016/j.jcis.2018.05.112
Liu, X., Lv, P., Yao, G., Ma, C., Huo, P., and Yan, Y. (2013). Microwave-assisted Synthesis of Selective Degradation Photocatalyst by Surface Molecular Imprinting Method for the Degradation of Tetracycline onto ClTiO2. Chem. Eng. J. 217, 398-406. doi:10.1016/j.cej.2012.12.007

Liu, Y., Tian, J., Wang, Q., Wei, L., Wang, C., and Yang, C. (2020). Enhanced Visible Light Photocatalytic Activity of G-C3n4 via the Synergistic Effect of K Atom Bridging Doping and Nanosheets Formed by thermal Exfoliation. Opt. Mater. 99, 109594. doi:10.1016/j.optmat.2019.109594

Liu, Y., Tian, J., Wei, L., Wang, Q., Wang, C., Xing, Z., et al. (2021). Modified G-C3N4/TiO2/CdS Ternary Heterojunction Nanocomposite as Highly Visible Light Active Photocatalyst Originated from CdS as the Electron Source of TiO2 to Accelerate Z-type Heterojunction. Separat. Purif. Techn. 257, 117976. doi:10.1016/j.seppur.2020.117976

Low, J., Yu, J., Jaroniec, M., Wageh, S., and Al-Ghamdi, A. A. (2017). Heterojunction Photocatalysts. Adv. Mater. 29 (20), 1601694. doi:10.1002/ adma.201601694

Lyu, J., Zhou, Z., Wang, Y., Li, J., Li, Q., Zhang, Y., et al. (2019). Platinum-enhanced Amorphous TiO2-Filled Mesoporous TiO2 Crystals for the Photocatalytic Mineralization of Tetracycline Hydrochloride. J. Hazard. Mater. 373, 278-284. doi:10.1016/j.jhazmat.2019.03.096

Ma, S., Gu, J., Han, Y., Gao, Y., Zong, Y., Ye, Z., et al. (2019). Facile Fabrication of C-TiO2 Nanocomposites with Enhanced Photocatalytic Activity for Degradation of Tetracycline. ACS Omega 4 (25), 21063-21071. doi:10.1021/ acsomega.9b02411

Mahdavi, H., Sajedi, M., Shahalizade, T., Heidari, A. A., and Bulletin, P. (2019). Preparation and Application of Catalytic Polymeric Membranes Based on PVDF/cobalt Nanoparticles Supported on MWCNTs. Polym. Bull. 77, 4489-4505. doi:10.1007/s00289-019-02983-w

Marcelino, R. B. P., and Amorim, C. C. (2019). Towards Visible-Light Photocatalysis for Environmental Applications: Band-gap Engineering versus Photons Absorption-A Review. Environ. Sci. Pollut. Res. 26 (5), 4155-4170. doi:10.1007/s11356-018-3117-5

Marchelek, M., Diak, M., Kozak, M., Zaleska-Medynska, A., and Grabowska, E. (2016). "Some Unitary, Binary, and Ternary Non-TiO2 Photocatalysts," in Semiconductor Photocatalysis - Materials, Mechanisms and Applications.

Marschall, R., and Wang, L. (2014). Non-metal Doping of Transition Metal Oxides for Visible-Light Photocatalysis. Catal. Today 225, 111-135. doi:10.1016/ j.cattod.2013.10.088

Minale, M., Gu, Z., Guadie, A., Kabtamu, D. M., Li, Y., and Wang, X. (2020). Application of Graphene-Based Materials for Removal of Tetracyclines Using Adsorption and Photocatalytic-Degradation: A Review. J. Environ. Manage. 276, 111310. doi:10.1016/j.jenvman.2020.111310

Mohd Adnan, M. A., Muhd Julkapli, N., Amir, M. N. I., and Maamor, A. (2018). Effect on Different TiO2 Photocatalyst Supports on Photodecolorization of Synthetic Dyes: a Review. Int. J. Environ. Sci. Techn. 16, 547-566. doi:10.1007/ s13762-018-1857-x

Mokh, S., El Hawari, K., Rahim, H. A., Al Iskandarani, M., and Jaber, F. (2020). Antimicrobial Residues Survey by LC-MS in Food-Producing Animals in Lebanon. Food Additives \& Contaminants: B 13 (2), 121-129. doi:10.1080/ 19393210.2020 .1739148

Mokh, S., El Khatib, M., Koubar, M., Daher, Z., and Al Iskandarani, M. (2017). Innovative SPE-LC-MS/MS Technique for the Assessment of 63 Pharmaceuticals and the Detection of Antibiotic-Resistant-Bacteria: A Case Study Natural Water Sources in Lebanon. Sci. Total Environ. 609, 830-841. doi:10.1016/j.scitotenv.2017.07.230

Mokhtari Nesfchi, M., Ebrahimian Pirbazari, A., Khalil Saraei, F. E., Rojaee, F., Mahdavi, F., and Fa'al Rastegar, S. A. (2021). Fabrication of Plasmonic Nanoparticles/Cobalt Doped $\mathrm{TiO} 2$ Nanosheets for Degradation of Tetracycline and Modeling the Process by Artificial Intelligence Techniques. Mater. Sci. Semiconductor Process. 122, 105465. doi:10.1016/ j.mssp.2020.105465

Mousavi, M., and Ghasemi, J. B. (2021). Novel Visible-Light-Responsive BlackTiO2/CoTiO3 Z-Scheme Heterojunction Photocatalyst with Efficient Photocatalytic Performance for the Degradation of Different Organic Dyes and Tetracycline. J. Taiwan Inst. Chem. Eng. 121, 168-183. doi:10.1016/ j.jtice.2021.04.009 
Navalon, S., Alvaro, M., and Garcia, H. (2008). Reaction of Chlorine Dioxide with Emergent Water Pollutants: Product Study of the Reaction of Three BetaLactam Antibiotics with $\mathrm{ClO}(2)$. Water Res. 42 (8), 1935-1942. doi:10.1016/ j.watres.2007.11.023

Niu, J., Ding, S., Zhang, L., Zhao, J., and Feng, C. (2013). Visible-lightmediated Sr-Bi2O3 Photocatalysis of Tetracycline: Kinetics, Mechanisms and Toxicity Assessment. Chemosphere 93 (1), 1-8. doi:10.1016/ j.chemosphere.2013.04.043

Niu, J., Lu, P., Kang, M., Deng, K., Yao, B., Yu, X., et al. (2014). P-doped TiO2 with superior Visible-Light Activity Prepared by Rapid Microwave Hydrothermal Method. Appl. Surf. Sci. 319, 99-106. doi:10.1016/j.apsusc.2014.07.048

Niu, X., Yan, W., Shao, C., Zhao, H., and Yang, J. (2019). Hydrothermal Synthesis of Mo-C Co-doped $\mathrm{TiO} 2$ and Coupled with Fluorine-Doped Tin Oxide (FTO) for High-Efficiency Photodegradation of Methylene Blue and Tetracycline: Effect of Donor-Acceptor Passivated Co-doping. Appl. Surf. Sci. 466, 882-892. doi:10.1016/j.apsusc.2018.10.019

Oseghe, E. O., and Ofomaja, A. E. (2018a). Facile Microwave Synthesis of pine Cone Derived C-Doped $\mathrm{TiO} 2$ for the Photodegradation of Tetracycline Hydrochloride under Visible-LED Light. J. Environ. Manage. 223, 860-867. doi:10.1016/j.jenvman.2018.07.003

Oseghe, E. O., and Ofomaja, A. E. (2018b). Study on Light Emission Diode/carbon Modified TiO2 System for Tetracycline Hydrochloride Degradation. J. Photochem. Photobiol. A: Chem. 360, 242-248. doi:10.1016/ j.jphotochem.2018.04.048

Ouyang, W., and Ji, Y. (2020). Facile Route for Porous N,S Co-doped TiO 2 Nanoparticles for Visible Light-driven Photocatalysis. Micro Nano Lett. 15 (8), 566-569. doi:10.1049/mnl.2020.0152

Palanivelu, K., Im, J.-S., and Lee, Y.-S. (2007). Carbon Doping of TiO2for Visible Light Photo Catalysis - A Review. Carbon Lett. 8, 214-224. doi:10.5714/ cl.2007.8.3.214

Pan, M., and Chu, L. M. (2017). Fate of Antibiotics in Soil and Their Uptake by Edible Crops. Sci. Total Environ. 599-600, 500-512. doi:10.1016/ j.scitotenv.2017.04.214

Pan, M., Wong, C. K. C., and Chu, L. M. (2014). Distribution of Antibiotics in Wastewater-Irrigated Soils and Their Accumulation in Vegetable Crops in the Pearl River Delta, Southern China. J. Agric. Food Chem. 62 (46), 11062-11069. doi:10.1021/jf503850v

Pang, S., Huang, J.-g., Su, Y., Geng, B., Lei, S.-y., Huang, Y.-t., et al. (2016). Synthesis and Modification of Zn-Doped TiO2Nanoparticles for the Photocatalytic Degradation of Tetracycline. Photochem. Photobiol. 92 (5), 651-657. doi:10.1111/php.12626

Pouretedal, H. R., and Afshari, B. (2016). Preparation and Characterization of $\mathrm{Zr}$ and Sn Doped TiO2nanocomposite and Photocatalytic Activity in Degradation of Tetracycline. Desalination Water Treat. 57 (23), 10941-10947. doi:10.1080/ 19443994.2015.1041056

Pudukudy, M., Jia, Q., Yuan, J., Megala, S., Rajendran, R., and Shan, S. (2020). Influence of $\mathrm{CeO} 2$ Loading on the Structural, Textural, Optical and Photocatalytic Properties of Single-Pot Sol-Gel Derived Ultrafine CeO2/ $\mathrm{TiO} 2$ Nanocomposites for the Efficient Degradation of Tetracycline under Visible Light Irradiation. Mater. Sci. Semiconductor Process. 108, 104891. doi:10.1016/j.mssp.2019.104891

Radjenović, J., Petrović, M., Ventura, F., and Barceló, D. (2008). Rejection of Pharmaceuticals in Nanofiltration and Reverse Osmosis Membrane Drinking Water Treatment. Water Res. 42 (14), 3601-3610. doi:10.1016/ j.watres.2008.05.020

Radwan, E. K., Langford, C. H., and Achari, G. (2018). Impact of Support Characteristics and Preparation Method on Photocatalytic Activity of TiO 2/ZSM-5/silica Gel Composite Photocatalyst. R. Soc. Open Sci. 5 (9), 180918. doi:10.1098/rsos.180918

Raschid-Sally, L., and Jayakody, P. (2008). Drivers and Characteristics of Wastewater Agriculture in Developing Countries: Results from a Global Assessment. Colombi, Sri Lanka: International Water Management Institute.

Rasheed, H. U., Lv, X., Wei, W., Yaseen, W., Ullah, N., Xie, J., et al. (2019). Synthesis and Studies of ZnO Doped with G-C3n4 Nanocomposites for the Degradation of Tetracycline Hydrochloride under the Visible Light Irradiation. J. Environ. Chem. Eng. 7 (3), 103152. doi:10.1016/j.jece.2019.103152

Rimoldi, L., Pargoletti, E., Meroni, D., Falletta, E., Cerrato, G., Turco, F., et al. (2018). Concurrent Role of Metal (Sn, Zn) and N Species in Enhancing the
Photocatalytic Activity of $\mathrm{TiO} 2$ under Solar Light. Catal. Today 313, 40-46. doi:10.1016/j.cattod.2017.12.017

Robles Jimenez, L. E., Angeles Hernandez, J. C., Osorio Avalos, J., Li, X., Atwill, E. R., Castelan Ortega, O., et al. (2019). "Veterinary Antibiotics in Animal Diet: Effects on Waste/Environment," in Bioactive Molecules in Food. Editors J.-M. Mérillon and K. G. Ramawat (Cham: Springer International Publishing), 1775-1792. doi:10.1007/978-3-319-78030-6_41

Saadati, F., Keramati, N., and Ghazi, M. M. (2016a). Influence of Parameters on the Photocatalytic Degradation of Tetracycline in Wastewater: A Review. Crit. Rev. Environ. Sci. Techn. 46 (8), 757-782. doi:10.1080/10643389.2016.1159093

Saadati, F., Keramati, N., and Mehdipour ghazi, M. (2016b). Synthesis of Nanocomposite Based on Semnan Natural Zeolite for Photocatalytic Degradation of Tetracycline under Visible Light. Adv. Environ. Techn. 2 (2), 63-70. doi:10.22104/aet.2016.399

Safari, G. H., Hoseini, M., Seyedsalehi, M., Kamani, H., Jaafari, J., and Mahvi, A. H. (2014). Photocatalytic Degradation of Tetracycline Using Nanosized Titanium Dioxide in Aqueous Solution. Int. J. Environ. Sci. Technol. 12 (2), 603-616. doi:10.1007/s13762-014-0706-9

Sanganyado, E., and Gwenzi, W. (2019). Antibiotic Resistance in Drinking Water Systems: Occurrence, Removal, and Human Health Risks. Sci. Total Environ. 669, 785-797. doi:10.1016/j.scitotenv.2019.03.162

Scaria, J., Karim, A. V., Divyapriya, G., Nidheesh, P. V., and Suresh Kumar, M. (2020). "Carbon-supported Semiconductor Nanoparticles as Effective Photocatalysts for Water and Wastewater Treatment," in Nano-Materials as Photocatalysts for Degradation of Environmental Pollutants. Editor P. Singh (Elsevier), 245-278. doi:10.1016/b978-0-12-818598-8.00013-4

Shen, J., Xue, J., Chen, Z., Ni, J., Tang, B., He, G., et al. (2018). One-step Hydrothermal Synthesis of Peony-like Ag/Bi2WO6 as Efficient Visible Light-Driven Photocatalyst toward Organic Pollutants Degradation. J. Mater. Sci. 53 (7), 4848-4860. doi:10.1007/s10853-017-1885-9

Singh, R., Singh, A. P., Kumar, S., Giri, B. S., and Kim, K.-H. (2019). Antibiotic Resistance in Major Rivers in the World: A Systematic Review on Occurrence, Emergence, and Management Strategies. J. Clean. Prod. 234, 1484-1505. doi:10.1016/j.jclepro.2019.06.243

Sommer, M. E., Elgeti, M., Hildebrand, P. W., Szczepek, M., Hofmann, K. P., and Scheerer, P. (2015). "Structure-Based Biophysical Analysis of the Interaction of Rhodopsin with G Protein and Arrestin," in Methods in Enzymology. Editor A. K. Shukla (Academic Press), 563-608. doi:10.1016/ bs.mie.2014.12.014

Song, J., Wu, X., Zhang, M., Liu, C., Yu, J., Sun, G., et al. (2020). Highly Flexible, Core-Shell Heterostructured, and Visible-Light-Driven Titania-Based Nanofibrous Membranes for Antibiotic Removal and E. Coil Inactivation. Chem. Eng. J. 379, 122269. doi:10.1016/j.cej.2019.122269

Sponza, D. T., and Koyuncuoglu, P. (2019). Photodegradation of Ciprofloxacin and Ofloxacin Antibiotics and Their Photo-Metabolites with Sunlight. Clin. Microbiol. Infect. Dis. 4. doi:10.15761/cmid.1000149

Stackelberg, P. E., Gibs, J., Furlong, E. T., Meyer, M. T., Zaugg, S. D., and Lippincott, R. L. (2007). Efficiency of Conventional Drinking-Water-Treatment Processes in Removal of Pharmaceuticals and Other Organic Compounds. Sci. Total Environ. 377 (2), 255-272. doi:10.1016/j.scitotenv.2007.01.095

Sun, J., Huang, D., Liu, R., Dai, J., and Chen, J. (2019). Photocatalytic Performance of $\mathrm{Ag} / \mathrm{AgBr}$ Modified TiO2: Critical Impacts and Wastewater Sample Study. J. Mater. Sci. Mater. Electron. 30 (16), 15754-15765. doi:10.1007/s10854-01901961-2

Sundar, K. P., and Kanmani, S. (2020). Progression of Photocatalytic Reactors and It's Comparison: A Review. Chem. Eng. Res. Des. 154, 135-150. doi:10.1016/ j.cherd.2019.11.035

Tabatabai-Yazdi, F. S., Ebrahimian Pirbazari, A., Esmaeili Khalilsaraei, F., Asasian Kolur, N., and Gilani, N. (2020). Photocatalytic Treatment of Tetracycline Antibiotic Wastewater by silver/TiO2 Nanosheets/reduced Graphene Oxide and Artificial Neural Network Modeling. Water Environ. Res. 92 (5), 662-676. doi:10.1002/wer.1258

Tang, X., Wang, Z., and Wang, Y. (2018). Visible Active N-Doped TiO2/reduced Graphene Oxide for the Degradation of Tetracycline Hydrochloride. Chem. Phys. Lett. 691, 408-414. doi:10.1016/j.cplett.2017.11.037

Teoh, W. Y., Scott, J. A., and Amal, R. (2012). Progress in Heterogeneous Photocatalysis: From Classical Radical Chemistry to Engineering Nanomaterials and Solar Reactors. J. Phys. Chem. Lett. 3 (5), 629-639. doi:10.1021/jz3000646 
Tong, H., Ouyang, S., Bi, Y., Umezawa, N., Oshikiri, M., and Ye, J. (2012). Nanophotocatalytic Materials: Possibilities and Challenges. Adv. Mater. 24 (2), 229-251. doi:10.1002/adma.201102752

Vázquez, A., Hernández-Uresti, D. B., and Obregón, S. (2016). Electrophoretic Deposition of CdS Coatings and Their Photocatalytic Activities in the Degradation of Tetracycline Antibiotic. Appl. Surf. Sci. 386, 412-417. doi:10.1016/j.apsusc.2016.06.034

Vieno, N. M., Härkki, H., Tuhkanen, T., and Kronberg, L. (2007). Occurrence of Pharmaceuticals in River Water and Their Elimination in a Pilot-Scale Drinking Water Treatment Plant. Environ. Sci. Technol. 41 (14), 5077-5084. doi:10.1021/es062720x

Wang, C., Wu, Y., Lu, J., Zhao, J., Cui, J., Wu, X., et al. (2017). Bioinspired Synthesis of Photocatalytic Nanocomposite Membranes Based on Synergy of Au-TiO2 and Polydopamine for Degradation of Tetracycline under Visible Light. ACS Appl. Mater. Inter. 9 (28), 23687-23697. doi:10.1021/ acsami.7b04902

Wang, H., Wu, D., Li, X., and Huo, P. (2019). Ce Doping TiO2/halloysite Nanotubes Photocatalyst for Enhanced Electrons Transfer and Photocatalytic Degradation of Tetracycline. J. Mater. Sci. Mater. Electron. 30 (21), 19126-19136. doi:10.1007/s10854-019-02268-y

Wang, P., Yap, P.-S., and Lim, T.-T. (2011). C-N-S Tridoped TiO2 for Photocatalytic Degradation of Tetracycline under Visible-Light Irradiation. Appl. Catal. A: Gen. 399 (1), 252-261. doi:10.1016/ j.apcata.2011.04.008

Wang, T., Quan, W., Jiang, D., Chen, L., Li, D., Meng, S., et al. (2016). Synthesis of Redox-mediator-free Direct Z-Scheme AgI/WO3 Nanocomposite Photocatalysts for the Degradation of Tetracycline with Enhanced Photocatalytic Activity. Chem. Eng. J. 300, 280-290. doi:10.1016/j.cej.2016.04.128

Wang, T., Zhong, S., Zou, S., Jiang, F., Feng, L., and Su, X. (2017). Novel Bi2 WO6 -coupled Fe3 O4 Magnetic Photocatalysts: Preparation, Characterization and Photodegradation of Tetracycline Hydrochloride. Photochem. Photobiol. 93 (4), 1034-1042. doi:10.1111/php.12739

Wang, W., Xiao, K., Zhu, L., Yin, Y., and Wang, Z. (2017). Graphene Oxide Supported Titanium Dioxide \& Ferroferric Oxide Hybrid, a Magnetically Separable Photocatalyst with Enhanced Photocatalytic Activity for Tetracycline Hydrochloride Degradation. RSC Adv. 7 (34), 21287-21297. doi:10.1039/c6ra28224e

Wei, Z., Liu, J., and Shangguan, W. (2020). A Review on Photocatalysis in Antibiotic Wastewater: Pollutant Degradation and Hydrogen Production. Chin. J. Catal. 41 (10), 1440-1450. doi:10.1016/s1872-2067(19)63448-0

Wu, G., Li, P., Xu, D., Luo, B., Hong, Y., Shi, W., et al. (2015). Hydrothermal Synthesis and Visible-Light-Driven Photocatalytic Degradation for Tetracycline of Mn-Doped SrTiO3 Nanocubes. Appl. Surf. Sci. 333, 39-47. doi:10.1016/j.apsusc.2015.02.008

Wu, Q. (2019). The Fabrication of Magnetic Recyclable Nitrogen Modified Titanium Dioxide/strontium Ferrite/diatomite Heterojunction Nanocomposite for Enhanced Visible-Light-Driven Photodegradation of Tetracycline. Int. J. Hydrogen Energ. 44 (16), 8261-8272. doi:10.1016/j.ijhydene.2019.01.145

Wu, S., Hu, H., Lin, Y., Zhang, J., and Hu, Y. H. (2020). Visible Light Photocatalytic Degradation of Tetracycline over TiO2. Chem. Eng. J. 382, 122842. doi:10.1016/ j.cej.2019.122842

Wu, X., Yin, S., Dong, Q., Guo, C., Li, H., Kimura, T., et al. (2013). Synthesis of High Visible Light Active Carbon Doped TiO2 Photocatalyst by a Facile Calcination Assisted Solvothermal Method. Appl. Catal. B: Environ. 142-143, 450-457. doi:10.1016/j.apcatb.2013.05.052

Xu, H., Ding, Y., Yang, S., Zhang, H., Wang, X., Yuan, J., et al. (2021). Carbon-doped Titania-Polymethylsilsesquioxane Aerogels for the Photocatalytic Degradation of Antibiotics. Bull. Mater. Sci. 44 (3), 226. doi:10.1007/s12034-021-02510-6

Xu, L., Zhang, H., Xiong, P., Zhu, Q., Liao, C., and Jiang, G. (2021). Occurrence, Fate, and Risk Assessment of Typical Tetracycline Antibiotics in the Aquatic Environment: A Review. Sci. Total Environ. 753, 141975. doi:10.1016/ j.scitotenv.2020.141975

Xu, P., Shen, X., Luo, L., Shi, Z., Liu, Z., Chen, Z., et al. (2018). Preparation of TiO2/ Bi2WO6 Nanostructured Heterojunctions on Carbon Fibers as a Weaveable VisibleLight Photocatalyst/photoelectrode. Environ. Sci. Nano 5 (2), 327-337. doi:10.1039/ c7en00822h

Yan, Q., Li, C., Lin, C., Zhao, Y., and Zhang, M. (2018). Visible Light Response $\mathrm{AgBr} / \mathrm{Ag} 3 \mathrm{PO} 4$ Hybrid for Removal of Anionic Dye and Tetracycline
Hydrochloride in Water. J. Mater. Sci. Mater. Electron. 29 (3), 2517-2524. doi:10.1007/s10854-017-8174-x

Yan, S., Yang, J., Li, Y., Jia, X., and Song, H. (2020). One-step Synthesis of ZnS/ BiOBr Photocatalyst to Enhance Photodegradation of Tetracycline under Full Spectral Irradiation. Mater. Lett. 276, 128232. doi:10.1016/j.matlet.2020.128232

Yang, W., Vogler, B., Lei, Y., and Wu, T. (2017). Metallic Ion Leaching from Heterogeneous Catalysts: an Overlooked Effect in the Study of Catalytic Ozonation Processes. Environ. Sci. Water Res. Technol. 3 (6), 1143-1151. doi:10.1039/c7ew00273d

Yang, X., Chen, Z., Zhao, W., Liu, C., Qian, X., Zhang, M., et al. (2021). Recent Advances in Photodegradation of Antibiotic Residues in Water. Chem. Eng. J. 405, 126806. doi:10.1016/j.cej.2020.126806

You, J., Guo, Y., Guo, R., and Liu, X. (2019). A Review of Visible Light-Active Photocatalysts for Water Disinfection: Features and Prospects. Chem. Eng. J. 373, 624-641. doi:10.1016/j.cej.2019.05.071

Yu, X., Lu, Z., Si, N., Zhou, W., Chen, T., Gao, X., et al. (2014). Preparation of Rare Earth Metal ion/TiO2Hal-Conducting Polymers by Ions Imprinting Technique and its Photodegradation Property on Tetracycline. Appl. Clay Sci. 99, 125-130. doi:10.1016/j.clay.2014.06.021

Yuan, J., Pudukudy, M., Hu, T., Liu, Y., Luo, X., Zhi, Y., et al. (2021). CeOx-coupled MIL125-Derived C-TiO2 Catalysts for the Enhanced Photocatalytic Abatement of Tetracycline under Visible Light Irradiation. Appl. Surf. Sci. 557, 149829. doi:10.1016/j.apsusc.2021.149829

Zeghioud, H., Khellaf, N., Djelal, H., Amrane, A., and Bouhelassa, M. (2016). Photocatalytic Reactors Dedicated to the Degradation of Hazardous Organic Pollutants: Kinetics, Mechanistic Aspects, and Design - A Review. Chem. Eng. Commun. 203 (11), 1415-1431. doi:10.1080/00986445.2016.1202243

Zhang, B., He, X., Ma, X., Chen, Q., Liu, G., Zhou, Y., et al. (2020). In Situ synthesis of Ultrafine TiO2 Nanoparticles Modified G-C3n4 Heterojunction Photocatalyst with Enhanced Photocatalytic Activity. Separat. Purif. Techn. 247, 116932. doi:10.1016/ j.seppur.2020.116932

Zhang, F. J., Li, R. S., Li, J. M., Liu, C. J., Jiang, C., and Kang, C. L. (2017). Preparation of $\mathrm{Zn}$ Doped $\mathrm{TiO}_{2}$ Nanoparticles Decorated on Graphene F or Photocatalytic Degradation of Tetracy Cline. Optoelectronics Adv. MaterialsRapid Commun. 11 (January-February 2017), 88-95.

Zhang, F., Wang, X., Liu, H., Liu, C., Wan, Y., Long, Y., et al. (2019). Recent Advances and Applications of Semiconductor Photocatalytic Technology. Appl. Sci. 9 (12), 2489. doi:10.3390/app9122489

Zhang, G., Guan, W., Shen, H., Zhang, X., Fan, W., Lu, C., et al. (2014). Organic Additives-free Hydrothermal Synthesis and Visible-Light-Driven Photodegradation of Tetracycline of WO3 Nanosheets. Ind. Eng. Chem. Res. 53 (13), 5443-5450. doi:10.1021/ie4036687

Zhang, G., Ji, S., and Xi, B. (2006). Feasibility Study of Treatment of Amoxillin Wastewater with a Combination of Extraction, Fenton Oxidation and Reverse Osmosis. Desalination 196 (1), 32-42. doi:10.1016/j.desal.2005.11.018

Zhang, Q.-Q., Ying, G.-G., Pan, C.-G., Liu, Y.-S., and Zhao, J.-L. (2015). Comprehensive Evaluation of Antibiotics Emission and Fate in the River Basins of China: Source Analysis, Multimedia Modeling, and Linkage to Bacterial Resistance. Environ. Sci. Technol. 49 (11), 6772-6782. doi:10.1021/acs.est.5b00729

Zhang, S., Xu, J., Hu, J., Cui, C., and Liu, H. (2017). Interfacial Growth of TiO2rGO Composite by Pickering Emulsion for Photocatalytic Degradation. Langmuir 33 (20), 5015-5024. doi:10.1021/acs.langmuir.7b00719

Zhang, S., Yin, Z., Xie, L., Yi, J., Tang, W., Tang, T., et al. (2020). Facet Engineered TiO2 Hollow Sphere for the Visible-Light-Mediated Degradation of Antibiotics via LigandTo-Metal Charge Transfer. Ceramics Int. 46 (7), 8949-8957. doi:10.1016/ j.ceramint.2019.12.142

Zhang, T., Liu, Y., Rao, Y., Li, X., Yuan, D., Tang, S., et al. (2020). Enhanced Photocatalytic Activity of $\mathrm{TiO} 2$ with Acetylene Black and Persulfate for Degradation of Tetracycline Hydrochloride under Visible Light. Chem. Eng. J. 384, 123350. doi:10.1016/j.cej.2019.123350

Zheng, X., Fu, W., Kang, F., Peng, H., and Wen, J. (2018). Enhanced PhotoFenton Degradation of Tetracycline Using TiO2-Coated $\alpha-\mathrm{Fe} 2 \mathrm{O} 3$ CoreShell Heterojunction. J. Ind. Eng. Chem. 68, 14-23. doi:10.1016/ j.jiec.2018.07.024

Zhu, X.-D., Wang, Y.-J., Sun, R.-J., and Zhou, D.-M. (2013). Photocatalytic Degradation of Tetracycline in Aqueous Solution by Nanosized TiO2. Chemosphere 92 (8), 925-932. doi:10.1016/ j.chemosphere.2013.02.066 
Zyoud, A., Jondi, W., AlDaqqah, N., Asaad, S., Qamhieh, N., Hajamohideen, A., et al. (2017). Self-sensitization of Tetracycline Degradation with Simulated Solar Light Catalyzed by ZnO@montmorillonite. Solid State. Sci. 74, 131-143. doi:10.1016/ j.solidstatesciences.2017.09.009

Conflict of Interest: The authors declare that the research was conducted in the absence of any commercial or financial relationships that could be construed as a potential conflict of interest.

Publisher's Note: All claims expressed in this article are solely those of the authors and do not necessarily represent those of their affiliated organizations, or those of the publisher, the editors and the reviewers. Any product that may be evaluated in this article, or claim that may be made by its manufacturer, is not guaranteed or endorsed by the publisher.

Copyright () 2021 Jalloul, Keniar, Tehrani and Boyadjian. This is an open-access article distributed under the terms of the Creative Commons Attribution License (CC $B Y)$. The use, distribution or reproduction in other forums is permitted, provided the original author(s) and the copyright owner(s) are credited and that the original publication in this journal is cited, in accordance with accepted academic practice. No use, distribution or reproduction is permitted which does not comply with these terms. 